\title{
Synthesis and Characterization of Novel Atypical Sphingoid Bases
}

Essa M. Saied ${ }^{1,2}$ and Christoph Arenz ${ }^{1 *}$

${ }^{1}$ Institute for Chemistry, Humboldt Universität zu Berlin, Brook-Taylor-Str. 2, 12489 Berlin, Germany.

${ }^{2}$ Chemistry Department, Faculty of Science, Suez Canal University, Ismailia, Egypt

* to whom correspondence should be submitted: arenzchr@hu-berlin.de

Keywords: Sphingolipids; Natural products; organic synthesis

\begin{abstract}
Sphingolipids represent an important class of eukaryotic membrane lipids. In mammals, sphingolipids are mostly characterized as derivatives of sphingosine, a long-chain 1,3dihydroxy-2-amino alcohol. Recently, more and more atypical sphingolipids have been discovered, which are often elevated under various pathological conditions and have the potential to become biomarkers for diseases such as diabetes mellitus. The synthesis and indepth chemical characterization of some recently discovered sphingosine bases is presented here.
\end{abstract}

\section{Introduction}

Sphingolipids (SL) are major components of all eukaryotic plasma membranes and characterized by hydroxyl amino alkanes, also termed long chain bases (LCB), as a core structural motif.[1-3] Key step for the synthesis of LCBs is the condensation reaction of Lserine and palmitoyl-CoA catalyzed by serine palmitoyl transferase (SPT) giving rise to C-18 3-Ketosphinganine, which is then reduced to sphinganine (also termed "dihydrosphingosine") followed by $\mathrm{N}$-acylation and desaturation at the $\Delta 4$ position to form ceramides (Figure 1). The latter serves as membrane anchor for more complex SL like glycosphingolipids (GSL) or the major plasma membrane lipid, sphingomyelin (SM).[1] Under physiological conditions, about $60 \%$ of all mammalian sphingolipids contain C-18 sphingosine as core LCB. The remaining LCB differ with respect to chain length, saturation and hydroxylation and other features.[4] In other species like plants and fungi (inclucing yeast), the fully saturated 1,3,5-trihydroxyl-2amino octadecane, phytosphingosine, is the major LCB, which also occurs in mammals, but only in rather small amounts. 

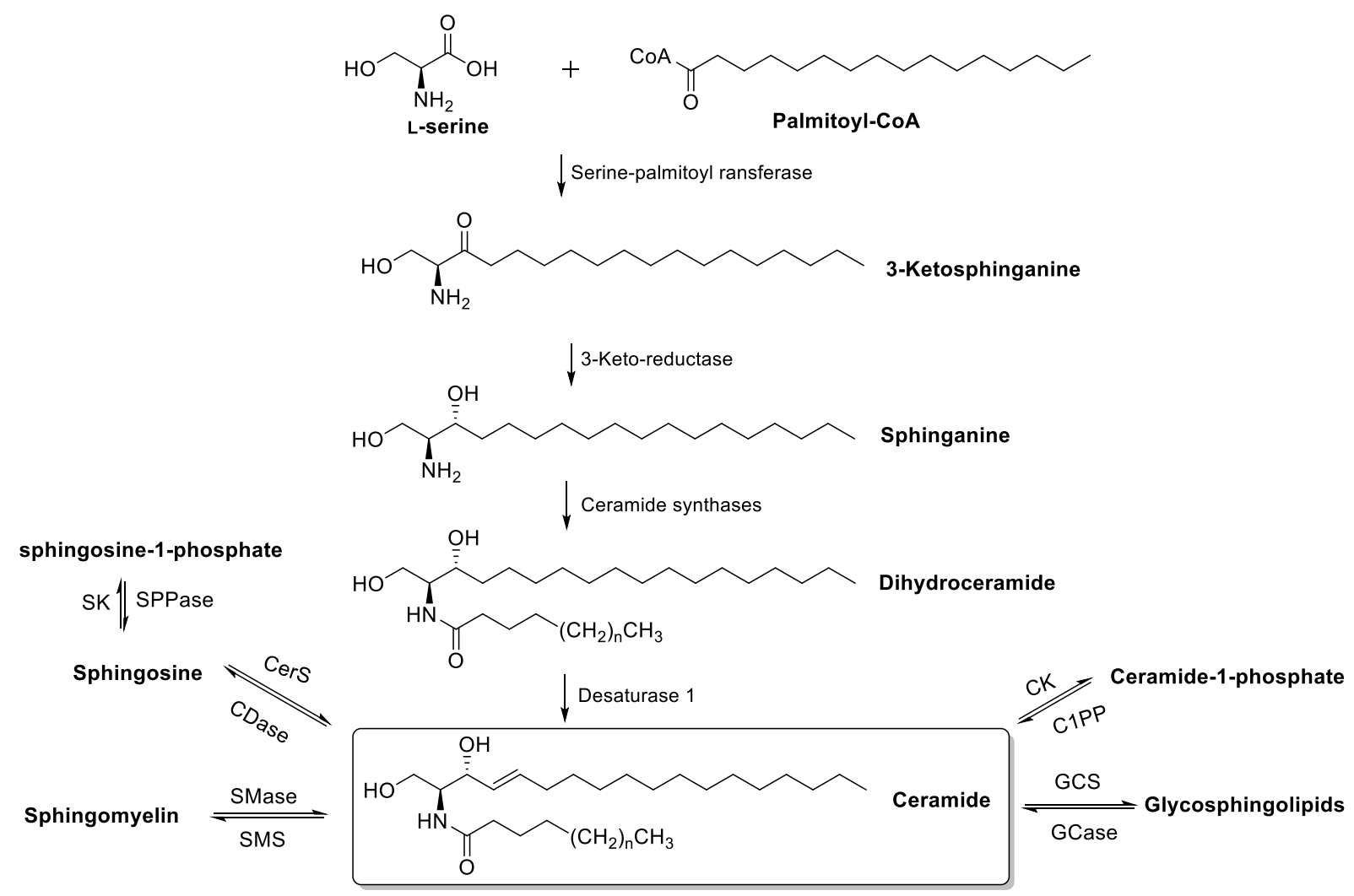

Figure 1: Metabolism of canonical sphingolipids. Various different headgroups can be added to ceramide to form different classes of complex sphingolipids. SMS, sphingomyelin synthase; SMase, sphingomyelinase; GCS, glucosyl-ceramide synthase; GCase, glucosyl ceramidase; CDase, ceramidase; CerS, ceramide synthase; CK, ceramide kinase; C1PP, ceramide-1phosphate phosphatase; SPPase, S1P phosphatase; SK, sphingosine kinase.

In the past, the head groups and acyl chains of more complex SL have been subject to intense research, while other modifications have been much less appreciated.[4] Among the known variations to the LCB part of sphingolipids, most are introduced downstream of the SPT reaction. This is especially true for unique modifications found in some pathogenic fungi, which are the result of atypical biosynthetic pathways, catalyzed by specialized enzymes, which might provide opportunities for targeted pharmacological strategies.[5, 6] Recently, a number of LCB based on an alternative use of the enzyme serine plamitoyl transferase have come into focus.

Research in this direction has been significantly triggered by the finding that the rare inherited neuropathy HSAN1, which is linked to mutations in the SPT gene, is correlated with highly elevated levels of LCBs devoid of the primary hydroxyl group.[7, 8] The resulting deoxysphingolipids and deoxymethyl sphingolipids are elevated due to a permanent shift in substrate preference of SPT from the canonical serine to alanine or glycine, respectively. Later it was shown that these lipids are not only neurotoxic, but also elevated in other diseases without mutations in the SPT gene, like in type II diabetes mellitus.[9, 10] The mechanisms that underlie these changes in LCB composition under pathological conditions are still unknown, but subject to intense research. 
SPT is a large enzyme complex consisting of the three key subunits SPTLC1, SPTLC2 and SPTLC3. SPTLC1 and SPTLC2 are essential and ubiquitously expressed,[11] while SPTLC3 expression occurs only in specific tissues.[12] SPT activity is controlled in a negative feedback mechanism through reversible phosphorylation of the two phospho-proteins, Orm1 and Orm2.[13] In yeast, another protein, Tsc3p is also required for maximal SPT activation.[14] In mammals and plants, the small subunits of SPT, ssSPTa and b are functional orthologues of Tsc3 and appear to modulate SPT activity and substrate affinity $[15,16]$ and recently a gain of activity mutation in ssSPTb was shown to pathologically increase C20 LCB formation in brain, leading to retinopathy and central neurodegeneration in mice.[15]

Clearly, aberrations in LCBs structure and distribution have key physiological or pathological consequences. For instance, the neurotoxicity of deoxy SL suggests their involvement in the occurrence of the frequent diabetic polyneuropathy.[9, 10, 17] Albeit, the exact molecular mechanism for the altered LCB formation in diabetes is still elusive. As LCBs derived from alanine or glycine instead of serine lack the primary hydroxyl group, formation of more complex sphingolipids via attachments of polar head groups is impossible. As a result, deoxyand deoxymethyl SL cannot be cleared via the usual catabolic pathways due to the lack of the canonical catabolic intermediate sphingosine-1-phosphate (S1P). Recently, we have elucidated the chemical structure of 1-deoxysphingosine, the major LCB derived from an alanine instead of serine incorporation into the SPT reaction. We revealed that the primary misguided metabolic step is followed by an unexpected non-canonical introduction of the double bond. Instead of the $5 \mathrm{E}$ a $14 \mathrm{Z}$ double bond was introduced.[18] It has been found that this double bond is formed by the desaturase FADS3, which is also responsible for introduction of the $14 \mathrm{Z}$ double bond in sphingadienine.[19] Furthermore, the alternative catabolism of this atypical LCB by members of the cytochrome P450 family and the resulting metabolites has been elucidated.[20] Notably, the metabolic intermediates that have characterized during these studies have the potential to serve as potential biomarkers, not only for diseases like HSAN1, but may be also be highly predictive for the occurrence of neuropathy in diabetic patients.

Herein, we describe the synthesis of novel atypical sphingolipids, which have been synthesized in the course of deciphering the mechanisms of LCB and SL biosynthesis in yeast and humans. Most of these compounds have been confirmed as naturally occurring metabolites or are currently under further investigation.

\section{Results and Discussion}

As mentioned above, phytosphingosine is the predominant LCB in plants and fungi, but also occurs in humans. In order to test, whether a deoxy-form of phytosphingosine exists, synthesis of 1-deoxysphingosine 7 was envisioned (scheme 1). Towards this end, commercial phytosphingosine was selectively N-protected using Boc-anhydride to form the intermediate 1 (not shown), which was followed by TBS-protection of the primary hydroxyl function to yield 
2. Acetal protection of the remaining hydroxyl groups yielded intermediate $\mathbf{3}$, which was treated with tert. Butyl amm0nium fluoride (TBAF) to yield 4. The thus-deprotected primary hydroxyl group was defunctionalized after mesylation and hydride substitution to form the protected precursor 6 of the desired compound 7. Application of this compound has been previously published.[16]

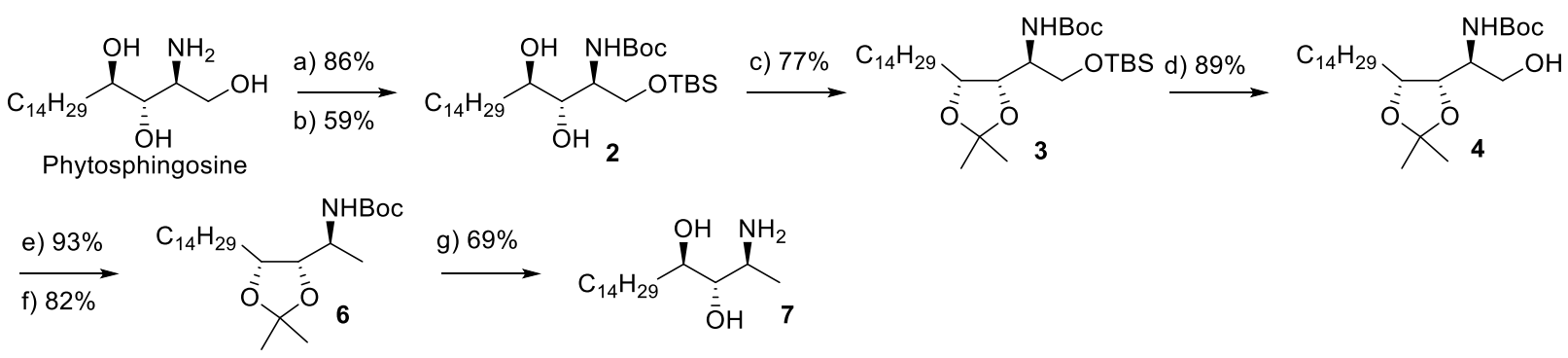

Scheme 1. Synthesis of 1-deoxy-phytosphingosine (7). Reagents and conditions: a) ( $t$-Boc) $)_{2} \mathrm{O}$, $1 \mathrm{M} \mathrm{NaOH}, \mathrm{EtOH}-\mathrm{H}_{2} \mathrm{O}, 0^{\circ} \mathrm{C}$ to r.t., 16h. b) TBSCl, 4-DMAP (cat.), $\mathrm{Et}_{3} \mathrm{~N}$, DCM, r.t., 4h. c) 2,2dimethoxypropane, $p$ - TsOH (cat.), toluene, $90^{\circ} \mathrm{C}, 2 \mathrm{~h}$. d) TBAF, THF, $60^{\circ} \mathrm{C}, 1 \mathrm{~h}$. e) $\mathrm{MsCl}, \mathrm{Et}_{3} \mathrm{~N}$, $\mathrm{DCM}, 40^{\circ} \mathrm{C}, 1 \mathrm{~h}$. f) $\mathrm{LiAlH}_{4}, \mathrm{THF},-15^{\circ} \mathrm{C}, 1 \mathrm{~h}$. g) $\mathrm{AcCl}, \mathrm{MeOH}, 0^{\circ} \mathrm{C}, 2 \mathrm{~h}$.

Next, we planned to synthesize 5E-1-deoxy-sphingosine 13. This compound differs from the originally postulated 1-deoxy-sphingosine by a double bond, shifted by one carbon position. This synthesis was achieved by a modification of the original sphingosine synthesis developed by Garner et al. in which a protected L-serinal is modified by nucleophilic attack.[21, 22] Here, we followed an alternative strategy by Yamamoto et al.[23] The group reacted the Weinreb amide of protected L-serine with vinyl magnesium bromide to form the respective $\alpha, \beta$ unsatured ketone. Similar approaches have since then been used to synthesize SL containing modified LCB.[24-26] Moreover, 1-deoxysphingosine derivatives have been synthesized, starting from L-alanine, instead of serine.[27-29] Here, the weinreb amide of L-alanine 9 was reacted with allyl magnesium bromide to form the ketone $\mathbf{1 0}$ (scheme 2). Stereoselective reduction yielded $\mathbf{1 1}$ in excellent yield, which was subjected to olefin metathesis to form the protected precursor 12. Deprotection of the Boc group yielded the desired compound 13.

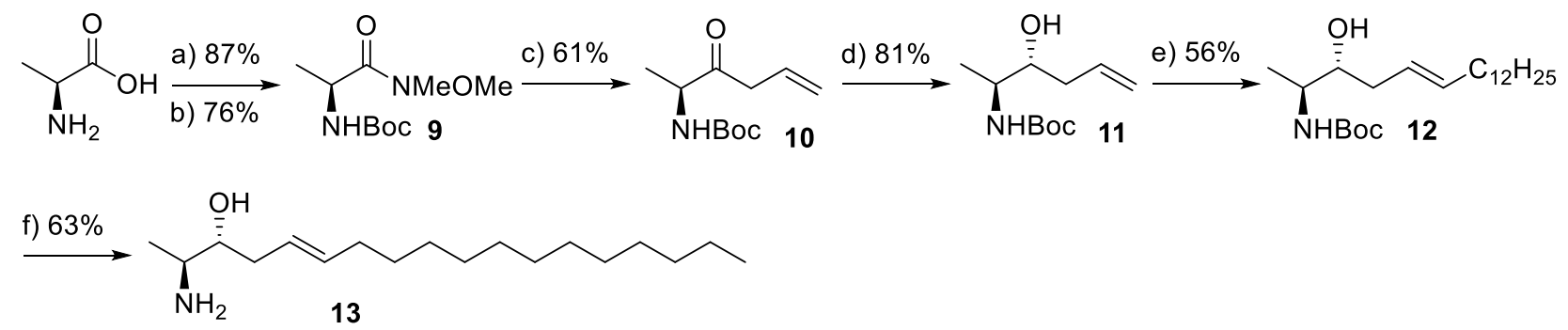

Scheme 2. Synthesis of 5E-1-deoxy-sphingosine (13). Reagents and conditions: a) $\mathrm{Boc}_{2} \mathrm{O}$, $1 \mathrm{M} \mathrm{NaOH}$, dioxane, $-10^{\circ} \mathrm{C}$ to r.t., $4 \mathrm{~h}$; b) $\mathrm{Me}(\mathrm{MeO}) \mathrm{NH} . \mathrm{HCl}$, EDCI.HCl, NMM, DCM, $-15^{\circ} \mathrm{C}$, 2h; c) (i) $\mathrm{Mg}, 1,2-\mathrm{DBE}, 1$-allylbromide, $\mathrm{Et}_{2} \mathrm{O}$, 3h, (ii) 9, $\mathrm{Et}_{2} \mathrm{O}, 0^{\circ} \mathrm{C}$ - r.t., 3h; d) TBLAH, 
EtOH, $-78^{\circ} \mathrm{C}, 2 \mathrm{~h}$; e) 1-tetradecene, $p$-benzoquinone (10 mol\%), Grubbs $2^{\text {nd }}$ generation cat.(10 $\mathrm{mol} \%), \mathrm{DCM}, 40^{\circ} \mathrm{C}, 12 \mathrm{~h}$; e) $\mathrm{AcCl}, \mathrm{MeOH}, 0^{\circ} \mathrm{C}$-r.t, $2 \mathrm{~h}$.

In the canonical SL biosynthesis, the SPT-mediated condensation step is followed by reduction of the ketone to yield sphinganine. In mammals, the desaturation takes place after $\mathrm{N}$ acylation.[30] We wanted to test, whether this regime might be changed during the synthesis of deoxy-SL. As a potential intermediate, synthesis of 3-keto-6E-1-deoxy-sphingosine $\mathbf{1 6}$ as was envisioned (scheme 3). The synthesis was achieved starting from 9 and the desired compound $\mathbf{1 6}$ was achieved in three steps with a total yield of $25 \%$ (scheme 3 ).

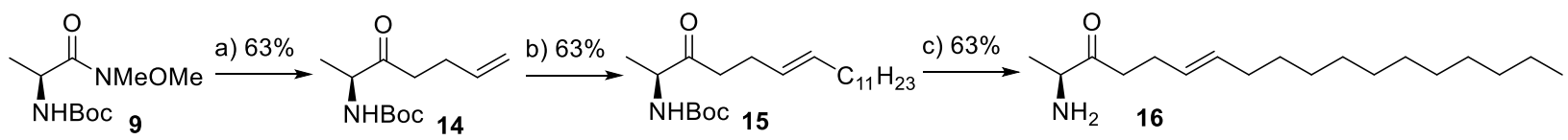

Scheme 3. Synthesis of 3-keto-6E-1-deoxy-sphingosine (16). Reagents and conditions: a) (i) $\mathrm{Mg}, 1$,2-DBE, 1-butylbromide, $\mathrm{Et}_{2} \mathrm{O}, 1 \mathrm{~h}$, (ii) 9, $\mathrm{Et}_{2} \mathrm{O}, 0^{\circ} \mathrm{C}$ - r.t., 2h; b) 1-tridecene, $p$ benzoquinone $(10 \mathrm{~mol} \%)$, Grubbs $2^{\text {nd }}$ generation cat. $\left.(8 \mathrm{~mol} \%), \mathrm{DCM}, 40^{\circ} \mathrm{C}, 6 \mathrm{~h} ; \mathrm{c}\right) \mathrm{AcCl}$, $\mathrm{MeOH}, 0^{\circ} \mathrm{C}-$ r.t, $2 \mathrm{~h}$.

The characterization of a cell's LCB content usually follows previous saponification of all SL. Therefore, it is unknown whether the desaturation step also occurs after $\mathrm{N}$-acylation or is independent from this step. A useful intermediate to follow up on this question is the 1deoxysphinganine 19. The latter was synthesized from 9 in three steps in very good yield (scheme 4). Instead of an unsaturated organic nucleophile, the Weinreb amide 9 was reacted with 1-bromopentadecane in the presence of metallic magnesium to form 17 . The latter was steroselectively reduced, followed by deprotection of the amino group to yield $\mathbf{1 9 .}$

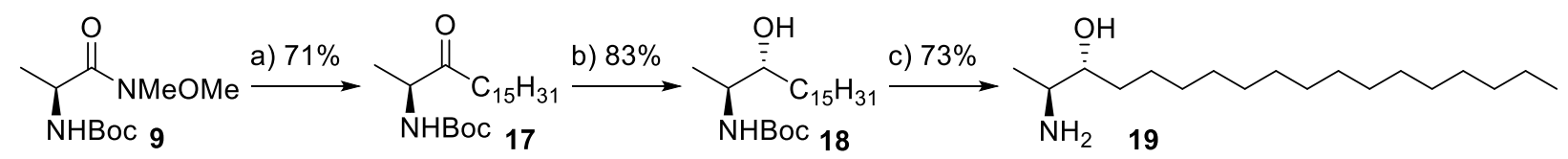

Scheme 4. Synthesis of 1-deoxy-sphinganine (19). Reagents and conditions: a) (i) Mg, 1,2DBE, 1-bromopentadecane, THF, 3h, (ii) 9, THF, $0^{\circ} \mathrm{C}$ - r.t., $2 \mathrm{~h}$; b) TBLAH, EtOH, $-78^{\circ} \mathrm{C}, 2 \mathrm{~h}$; c) $\mathrm{AcCl}, \mathrm{MeOH}, 0^{\circ} \mathrm{C}-$ r.t, $2 \mathrm{~h}$.

The final elucidation of the structure of 1-deoxy-sphingosine makes it a potential biomarker for diabetic retinopathy. Therefore we aimed at synthesizing a deuterated MS standard (scheme 5). Towards this end, 9 was converted into the w-bromocompound $\mathbf{2 7}$ followed by deuteration of the double bond to yield $\mathbf{2 8}$. The latter was reacted with dimethoxy propane and the resulting 
intermediate 29 was reacted with 1-pentyne in presence of tert.-BuLi. The resulting intermediate $\mathbf{3 0}$ was selectively converted to the Z-alkene $\mathbf{3 1}$ and the desired deuterated 1deoxy-sphingosine 32 was achieved after deprotection.

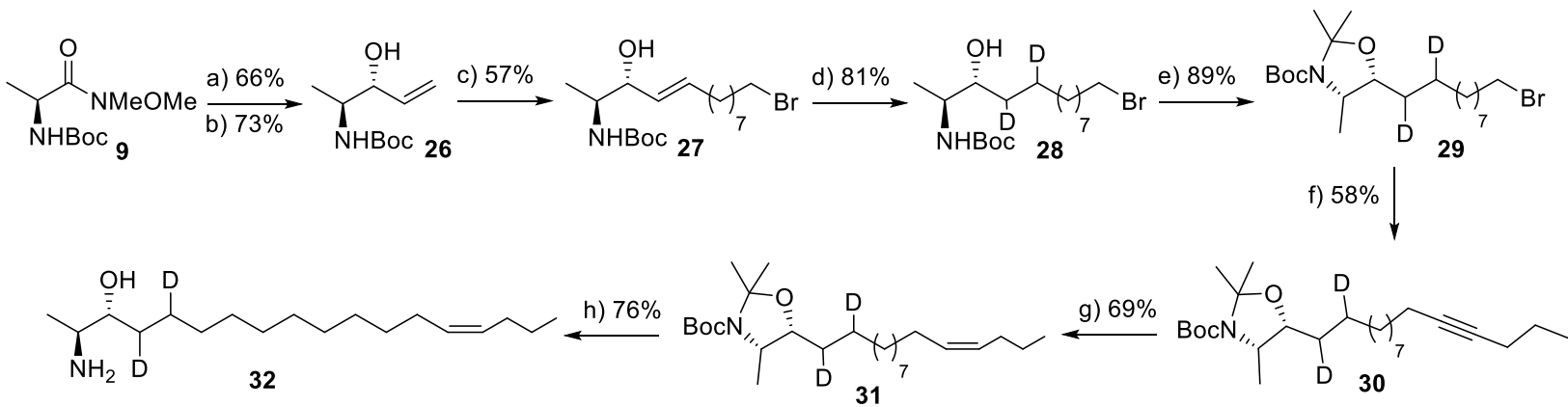

Scheme 5. Synthesis of 14Z-1-deoxy-sphingosine- $\boldsymbol{d}_{2}$ (32). Reagents and conditions: a) vinylmagnesium bromide (1M in THF), THF, $-20^{\circ} \mathrm{C}-$ r.t., $4 \mathrm{~h}$; b) TBLAH, EtOH, $-78^{\circ} \mathrm{C}, 3 \mathrm{~h}$; c) 10-bromo-1-decene, $p$-benzoquinone (10 mol\%), Grubbs $2^{\text {nd }}$ generation cat.(10 mol\%), DCM, $40^{\circ} \mathrm{C}, 12 \mathrm{~h}$; d) $\mathrm{D}_{2}, 10 \% \mathrm{Pd} / \mathrm{C}$, d-acetic acid (cat.), d-Methanol, rt, 14h; e) 2,2dimethoxypropane, $p$-TsOH (cat.), toluene, reflux, $2 \mathrm{~h}$; f) (i) 1-pentyne, tert-BuLi, THF, $-78^{\circ} \mathrm{C}$, (ii) 29, HMPA, THF, $-78^{\circ} \mathrm{C}$ - r.t.,12h; g) $\mathrm{H}_{2}$, Lindlar cat., EtOAc, DMF, r.t., 16h; h) $\mathrm{AcCl}$, $\mathrm{MeOH}, 0^{\circ} \mathrm{C}-$ r.t, $2 \mathrm{~h}$.

Next, we wanted to synthesize an MS standard for the canonical 3-ketosphinganine. Towards this goal, L-serine was converted into the respective Boc-protected Weinreb amide 34 (scheme 6). This was followed by reaction with vinyl magnesium bromide to yield $\mathbf{3 5}$, as described previously.[28] After the essential olefin metathesis, the resulting intermediate $\mathbf{3 6}$ was deuterated to yield the target molecule 37 .

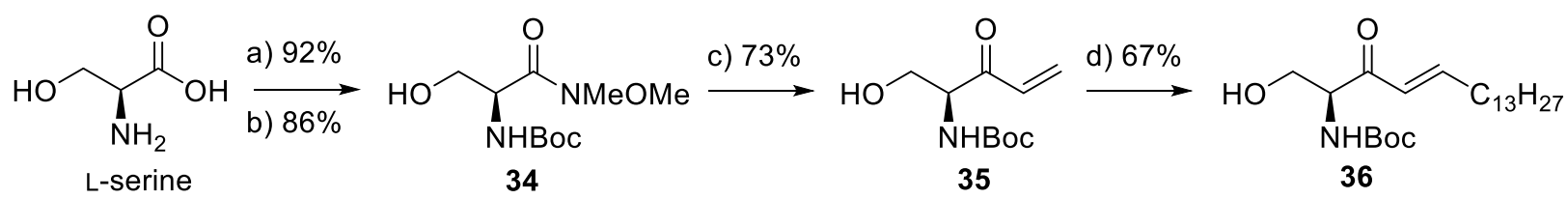<smiles>[2H]C(CCCCCCCCCCCCC)C([B])C(=O)C(N)CO</smiles>

Scheme 6. Synthesis of 3-ketosphinganine- $\boldsymbol{d}_{2}$ (37). Reagents and conditions: a) $\mathrm{Boc}_{2} \mathrm{O}, 1 \mathrm{M}$ $\mathrm{NaOH}$, dioxane, $-10^{\circ} \mathrm{C}$ to r.t., $4 \mathrm{~h}$; b) $\mathrm{Me}(\mathrm{MeO}) \mathrm{NH} . \mathrm{HCl}$, EDCI.HCl, NMM, DCM, $-15^{\circ} \mathrm{C}, 2 \mathrm{~h}$; c) (i) $\mathrm{n}-\mathrm{BuLi}$, THF, $-65^{\circ} \mathrm{C}, 30 \mathrm{~min}$, (ii) vinylmagnesium bromide $(1 \mathrm{M}$ in $\mathrm{THF}),-65^{\circ} \mathrm{C}-$ r.t., $6 \mathrm{~h}$; d) 1-pentadecene, Grubbs $2^{\text {nd }}$ generation cat.(7 mol\%), $\mathrm{DCM}, 40^{\circ} \mathrm{C}, 6 \mathrm{~h}$; e) (i) $\mathrm{D}_{2}, 10 \% \mathrm{Pd} / \mathrm{C}$, d-acetic acid (cat.), d-Methanol, rt, 12h, (ii) $2 \mathrm{M} \mathrm{HCl}$, THF-MeOH, reflux, $2 \mathrm{~h}$. 
In the course of our ongoing studies, the methyl-branched LCB 49 was postulated (unpublished results). To proof this hypothesis, the target compound was synthesized as depicted in scheme 7. The long chain terminal diol 9 was protected with a single THP group as described above. Then, the resulting $\mathbf{3 8}$ was brominated followed by Br-elimination to yield the terminal alkene 40. After deprotection the hydroxyl group was tosylated and reacted with the branched building block 45 in presence of metallic magnesium. The branched alkene 46 was then reacted in an olefin metathesis with the previously described intermediate 47.[28] Final deprotection yielded the desired branched LCB 49.

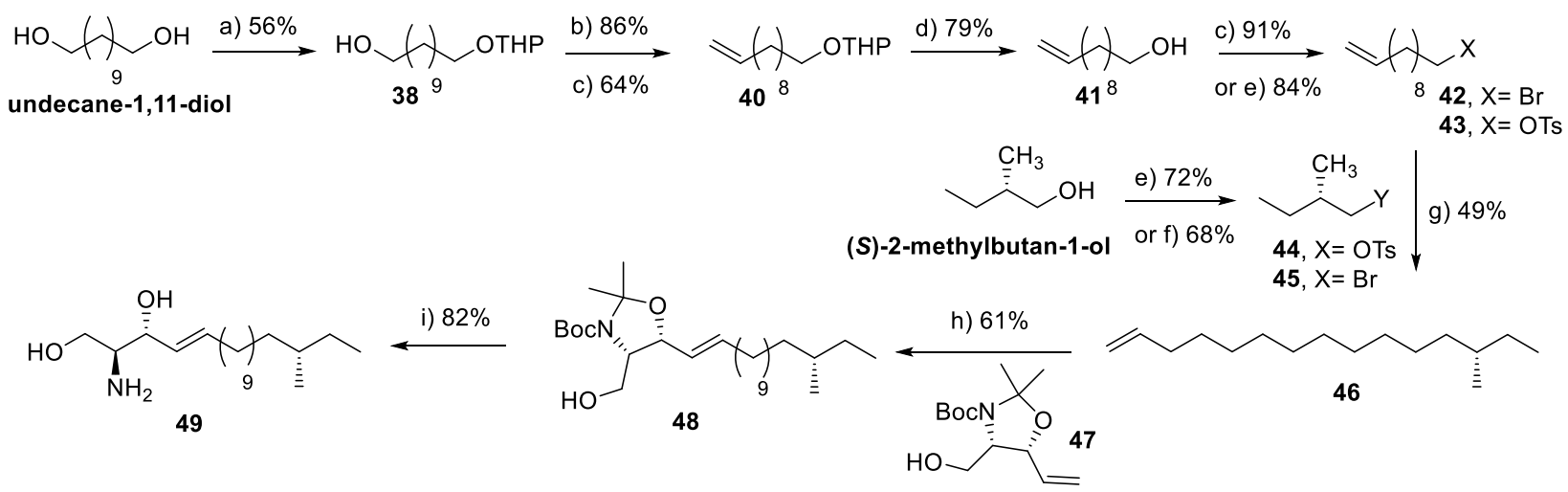

Scheme 7. Synthesis of (16S)-Methyl-sphingosine (49). Reagents and conditions: a) DHP, PTSA (cat.), THF, $0^{\circ} \mathrm{C}$-rt, $16 \mathrm{~h}$; b) $\mathrm{CBr}_{4}, \mathrm{PPh}_{3}$, DCM, $0{ }^{\circ} \mathrm{C}$-rt, 4h; d) PPTS (cat.), EtOH, $62^{\circ} \mathrm{C}$, 2h; e) TsCl, pyridine, DCM, $0^{\circ} \mathrm{C}$-rt, $16 \mathrm{~h}$; f) $\mathrm{NBS}, \mathrm{PPh}_{3}, \mathrm{DCM}, 0^{\circ} \mathrm{C}-\mathrm{rt}, 2 \mathrm{~h}$; g) (i) 45, $\mathrm{Mg}$, THF, $30^{\circ} \mathrm{C}, 90 \mathrm{~min}$, and then (ii) $43, \mathrm{Li}_{2} \mathrm{CuCl}_{4}$ (cat), THF, $-78^{\circ} \mathrm{C}-\mathrm{rt}, 16 \mathrm{~h}$; h) 47 , Grubbs $2^{\text {nd }}$ generation (cat.), DCM, reflux, 12h; i) $\mathrm{AcCl}, \mathrm{MeOH}, 0^{\circ} \mathrm{C}-\mathrm{rt}, 2 \mathrm{~h}$.

\section{Conclusion}

Here, we have described the synthesis of several novel atypical sphingolipid LCB.

\section{Experimental}

\subsection{General description of materials and methods}

Unless otherwise specified, all reactions were carried out in oven-dried $\left(>120^{\circ} \mathrm{C}\right)$ glassware equipped with a magnetic stir bar and a rubber septum under a positive pressure of argon. Air- or moisturesensitive reagents were transferred to the reaction vessel under positive pressure of argon via syringe. Air and/or moisture sensitive reactions were carried out in well dried glassware under an argon atmosphere with dry, freshly distilled solvents using standard syringe-cannula/septa techniques. Reactions were run at room temperature $\left(20-25^{\circ} \mathrm{C}\right)$ unless otherwise noted in the experimental procedure, and reported reaction temperatures refer to the external temperatures measured for the bath in which the reaction vessel was immersed. Heating was obtained through the use of a silicone oil bath. For reactions run below room temperature, the term " $-78^{\circ} \mathrm{C}$ " refers to a bath of acetone and dry ice, "- 
$20^{\circ} \mathrm{C}$ " refers to a slurry of sodium chloride and ice-water bath, and " $0{ }^{\circ} \mathrm{C}$ " refers to an ice-water bath. Removal of residual solvents was accomplished by evacuation of the container for a period of 12-20 hours using a high vacuum line.

\section{Reagents and solvents}

All the commercially available reagents were purchased from Sigma-Aldrich, TCI, Fluka or Acros and used without further purification, unless otherwise specified. All the solvents were used after distillation by standard methods. The petroleum ether used throughout this study had a boiling range of $40-60^{\circ} \mathrm{C}$.

\section{Chromatography}

The thin layer chromatography studies were performed on pre-coated silica gel $60-\mathrm{F}_{254}$ on aluminum sheets (Merck KGaA) and spots were detected by UV illumination $(254 \mathrm{~nm})$, and/or spraying with $1.3 \%$ ninhydrin solution, ceric ammonium molybdate (Seebach reagent) solution $\left(25 \mathrm{~g} \mathrm{MoO} \cdot \mathrm{H}_{3} \mathrm{PO}_{4} \cdot \mathrm{H}_{2} \mathrm{O}\right.$, $10 \mathrm{~g} \mathrm{Ce}\left(\mathrm{SO}_{4}\right)_{2} \cdot 4 \mathrm{H}_{2} \mathrm{O}, 60 \mathrm{ml} \mathrm{H}_{2} \mathrm{SO}_{4}$ and $905 \mathrm{ml}$ of $\left.\mathrm{H}_{2} \mathrm{O}\right)$ or $\mathrm{KMnO}_{4}$ solution $\left(1.5 \mathrm{~g} \mathrm{KMnO}_{4}, 10 \mathrm{~g} \mathrm{~K}_{2} \mathrm{CO}_{3}\right.$ and $1.25 \mathrm{ml} 10 \% \mathrm{NaOH}$ in $200 \mathrm{ml}$ water) followed by heating. Preparative flash column chromatography was performed manually using glass columns of different size packed with Silica Gel 60M (0.04-0.063 $\mathrm{mm}$ ) as stationary phase with indicated eluent systems in parenthesis following the description of purification. Solvent ratios for chromatography and $\mathrm{R}_{\mathrm{f}}$ values are reported in $\mathrm{v} / \mathrm{v} \%$ ratios.

\section{Spectroscopic Data}

The structure of all synthesized compounds was confirmed with ${ }^{1} \mathrm{H}$ NMR, ${ }^{13} \mathrm{C}$ NMR, DEPT, ${ }^{31} \mathrm{P}$ NMR and MS analysis. ${ }^{1} \mathrm{H},{ }^{13} \mathrm{C}$ and ${ }^{31} \mathrm{P}$ NMR spectra were recorded on Bruker AVANCE II 300, AVANCED PX 300, AVANCE 400 and Bruker ADVANCE III 500 spectrometers $\left({ }^{1} \mathrm{H}\right.$ at 300, 400 or $500 \mathrm{MHz},{ }^{13} \mathrm{C}$ at $75.4,101.2$ or $125.7 \mathrm{MHz}$ and ${ }^{31} \mathrm{P}$ at 161.9 or $202.4 \mathrm{~Hz}$ ) as solutions in $\mathrm{CDCl}_{3}, \mathrm{CD}_{3} \mathrm{OD}$ or mixtures of those at $25^{\circ} \mathrm{C}$. Chemical shifts $(\delta)$ are reported in parts per million (ppm): multiplicities are indicated as s (singlet), $d$ (doublet), $t$ (triplet), q (quartet), $m$ (multiplet) and br (broad). Chemical shifts are given in ppm with respect to TMS as an external standard, $\left({ }^{1} \mathrm{H}, \mathrm{APT},{ }^{13} \mathrm{C}, \delta=0.00\right)$ with calibration against the residual solvent signal or $85 \% \mathrm{H}_{3} \mathrm{PO}_{4}\left({ }^{31} \mathrm{P}, \delta=0.00\right)$ as external standard. The coupling constants $J$ are given in $\mathrm{Hz}$.

\section{Mass Spectroscopy}

Mass spectroscopy (MS) experiments were recorded on an AGILENT 6120 UPLC-MS system consisting of an SQD (single quadrupole detector) mass spectrometer equipped with an electrospray ionization interface (ESI) in the positive and negative ion detection modes. The samples were separated on a Zorbax Eclipse Plus C18 column (particle size $1.8 \mu \mathrm{m}, 2.1 \times 50 \mathrm{~mm}$ ) using a UPLC pump at a flow rate of $0.8 \mathrm{ml}$ per min with a ternary solvent system of $\mathrm{MeOH}-\mathrm{H}_{2} \mathrm{O}-\mathrm{HCOOH}$, methanol $(99.9 \%$ $\mathrm{MeOH}: 0.1 \% \mathrm{HCOOH}, \mathrm{v} / \mathrm{v})$. The column was first equilibrated using a mixture of $95 \%$ mobile phase A and $5 \%$ mobile phase $\mathrm{B}$, and then $10 \mu 1$ of the sample was injected. This was followed by a ramp gradient over 2 min to $95 \%$ phase B and $5 \%$ phase A, which remained until 7 min, followed by a ramp gradient back down to $95 \%$ solvent A and 5\% solvent B for $1 \mathrm{~min}$, and column equilibration with the same mixture for $1 \mathrm{~min}$. The detection was performed in full scan mode and the major observable molecular ion and selected fragments and clusters have been reported.

\section{(2S,3S,4R)-tert-butyl-(1,3,4-trihydroxyoctadecan-2-yl)carbamate (1)}


A suspension of phytosphingosine $(1.0 \mathrm{~g}, 3.15 \mathrm{mmol})$ in a mixture of ethanol $(20 \mathrm{~mL})$ and water $(10 \mathrm{~mL})$ at ambient temperature was treated with a solution of $1 \mathrm{M} \mathrm{NaOH}(4 \mathrm{~mL}$, until $\mathrm{pH}=8)$. After the resulting mixture was cooled to $0^{\circ} \mathrm{C}$, di-tert-butyldicarbonate $(1.1 \mathrm{~g}, 4.73 \mathrm{mmol})$ was added in portions. The resulting reaction mixture was allowed to stir at ambient temperature for $16 \mathrm{~h}$ (as indicated by TLC analysis for complete reaction), and subsequently was quenched with $1 \mathrm{M} \mathrm{HCl}$ solution $(50 \mathrm{~mL})$. The resulting mixture was extracted with ethylacetate $(3 \times 80 \mathrm{~mL})$, and the combined organic layers were washed with brine $(100 \mathrm{~mL})$, dried over anhydrous $\mathrm{Na}_{2} \mathrm{SO}_{4}$, filtered and concentrated in vacuo to provide compound $\mathbf{1}$ as a white solid. The product was used in the next step without any further purification.

Yield: $1.53 \mathrm{~g}$, (86\%). Rf: 0.4 (EtOAc 100\%, visualized with $1.3 \%$ ninhydrine). ${ }^{1} \mathrm{H} \mathrm{NMR}\left(\mathrm{CDCl}_{3}\right.$, $500 \mathrm{MHz}, \mathrm{ppm}): \delta 5.46$ (d, $J=6.7 \mathrm{~Hz}, 1 \mathrm{H}), 3.92-3.62(\mathrm{~m}, 5 \mathrm{H}), 3.17$ (br s, $1 \mathrm{H}), 1.45$ (s, $9 \mathrm{H})$, $1.38-1.18(\mathrm{~m}, 26 \mathrm{H}), 0.89$ (t, $J=6.9 \mathrm{~Hz}, 3 \mathrm{H}) .{ }^{13} \mathrm{C}-\mathrm{NMR}\left(\mathrm{CDCl}_{3}, 125 \mathrm{MHz}, \mathrm{ppm}\right) \delta 156.5,80.2$, 76.7, 73.0, 62.1, 53.1, 33.2, 31.9, 30.0, 29.7, 29.6, 29.3, 28.4, 25.9, 22.7, 14.1. ESI-MS m/z $(\mathrm{M}+\mathrm{Na})^{+} 440.3$.

\section{(2S,3S,4R)-tert-butyl-1-((tert-butyldimethylsilyl)oxy)-3,4-dihydroxyoctadecan-2-yl)- carbamate (2)}

To a stirred solution of compound $1(1.0 \mathrm{~g}, 2.4 \mathrm{mmol})$ in dry DCM $(52 \mathrm{~mL})$ at $0^{\circ} \mathrm{C}$ under argon atmosphere was added triethylamine $(385 \mu \mathrm{l}, 2.75 \mathrm{mmol})$, followed by a catalytic amount of 4(dimethylamino)-pyridine (4-DMAP, $29 \mathrm{mg}, 10 \mathrm{~mol} \%$ ). After being stirred at the same conditions for $10 \mathrm{~min}$, the resulting mixture was treated with tert-butyldimethylsilyl chloride (TBSCl, $0.41 \mathrm{~g}, 2.75 \mathrm{mmol}$ ) in portions over a period of $10 \mathrm{~min}$. The resulting reaction mixture was allowed to stir at ambient temperature for $2 \mathrm{~h}$ (as monitored by TLC analysis), before it was quenched with methanol $(10 \mathrm{~mL})$. The resulting mixture was diluted with DCM (100 mL), and sequentially washed with $1 \% \mathrm{HCl}$ solution $(80 \mathrm{~mL})$, saturated $\mathrm{NaHCO}_{3}$ solution $(80 \mathrm{~mL})$, and brine $(80 \mathrm{~mL})$. The organic phase was then dried over anhydrous $\mathrm{Na}_{2} \mathrm{SO}_{4}$, filtered and concentrated in vacuo. Flash column chromatography of the obtained crude residue over silica gel using cyclohexane and ethylacetate as eluents (from 5-15\% ethylacetate in cyclohexane) provided the desired product $\mathbf{2}$ as a pale yellow oil.

Yield: $0.75 \mathrm{~g},(59 \%) . \mathrm{R}_{f}$ : 0.65 (cyclohexane / EtOAc 3:2, visualized with $1.3 \%$ ninhydrine). ${ }^{1} \mathrm{H}$ NMR $\left(\mathrm{CDCl}_{3}, 500 \mathrm{MHz}, \mathrm{ppm}\right): \delta 5.17(\mathrm{~d}, J=7.4 \mathrm{~Hz}, 1 \mathrm{H}), 4.01$ (d, $\left.J=9.7 \mathrm{~Hz}, 1 \mathrm{H}\right), 3.87$ (br.s, $1 \mathrm{H}), 3.85-3.79(\mathrm{~m}, 1 \mathrm{H}), 3.67-3.58(\mathrm{~m}, 2 \mathrm{H}), 1.64-1.27(\mathrm{~m}, 35 \mathrm{H}), 0.91(\mathrm{~s}, 9 \mathrm{H}), 0.89(\mathrm{t}, J=6.8$ $\mathrm{Hz}, 3 \mathrm{H}), 0.13$ (s, $6 \mathrm{H}) .{ }^{13} \mathrm{C}-\mathrm{NMR}\left(\mathrm{CDCl}_{3}, 125 \mathrm{MHz}, \mathrm{ppm}\right) \delta 155.6,108.2,76.0,73.4,62.9,51.7$, $33.4,32.0,29.8,29.7,29.6,29.4,28.4,25.9,25.9,22.7,14.2,-5.5$. ESI-MS $m / z(\mathrm{M}+\mathrm{H})^{+} 532.4$.

\section{tert-Butyl((S)-2-((tert-butyldimethylsilyl)oxy)-1-((4S,5R)-2,2-dimethyl-5-tetradecyl-1,3- di-oxolan -4-yl)ethyl)carbamate (3)}

A stirred solution of compound $2(700 \mathrm{mg}, 1.32 \mathrm{mmol})$ in anhydrous toluene $(7 \mathrm{~mL})$ under an argon atmosphere was treated with 2,2-dimethoxypropane $(650 \mu \mathrm{L}, 5.3 \mathrm{mmol})$, followed by a catalytic amount of $p$-toluensulfonic acid monohydrate ( $p$-TsOH, $25 \mathrm{mg}, 10 \mathrm{~mol} \%$ ). After the resulting reaction mixture was allowed to stir under reflux for $1 \mathrm{~h}$ (as judged by the TLC analysis, visualized with $\mathrm{KMnO}_{4}$ solution), the reaction mixture was cooled to ambient temperature, diluted with ethylacetate, and carefully quenched with saturated $\mathrm{NaHCO}_{3}$ solution 
$(100 \mathrm{~mL})$. The layers were separated, and the aqueous layer was extracted with ethylacetate $(3 \times 80 \mathrm{~mL})$. The organic layers were combined, washed with brine $(150 \mathrm{~mL})$, dried over anhydrous $\mathrm{Na}_{2} \mathrm{SO}_{4}$, filtered and concentrated under reduced pressure. Purification of the obtained crude mixture by flash column chromatography over silica gel using petroleum ether and ethylacetate as eluents (from $0 \%$ to $2.5 \%$ ethylacetate in petroleum ether) afforded the desired product $\mathbf{3}$ as a colorless solid.

Yield: $580 \mathrm{mg}$, (77\%). Rf: 0.66 (cyclohexane / EtOAc 95:5, visualized with 1.3\% ninhydrine). ${ }^{1} \mathrm{H} \mathrm{NMR}\left(\mathrm{CDCl}_{3}, 500 \mathrm{MHz}, \mathrm{ppm}\right): \delta 4.72(\mathrm{~d}, J=9.6 \mathrm{~Hz}, 1 \mathrm{H}), 4.10-4.00(\mathrm{~m}, 2 \mathrm{H}), 3.83(\mathrm{dd}, J$ $=9.8 \mathrm{~Hz}, 1 \mathrm{H}), 3.74(\mathrm{~m}, 1 \mathrm{H}), 3.68-3.61(\mathrm{~m}, 1 \mathrm{H}), 1.58-1.40(\mathrm{~m}, 14 \mathrm{H}), 1.32-1.23(\mathrm{~m}, 27 \mathrm{H}), 0.89$ $(\mathrm{s}, 9 \mathrm{H}), 0.87(\mathrm{t}, J=6.9 \mathrm{~Hz}, 3 \mathrm{H}), 0.05(\mathrm{~s}, 6 \mathrm{H}) .{ }^{13} \mathrm{C}-\mathrm{NMR}\left(\mathrm{CDCl}_{3}, 125 \mathrm{MHz}, \mathrm{ppm}\right) \delta 155.2$, 107.9, 79.5, 78.1, 75.7, 63.0, 50.9, 32.1, 29.8, 29.8, 29.7, 29.5, 28.5, 26.0, 22.8, 18.5, 14.3, 5.3. ESI-MS $m / z(\mathrm{M}+\mathrm{H})^{+} 572.4$.

\section{tert-Butyl-((S)-1-((4S,5R)-2,2-dimethyl-5-tetradecyl-1,3-dioxolan-4-yl)-2-hydroxyethyl)- carbamate (4)}

A solution of n-tetrabutylammonium fluoride (TBAF, $2.6 \mathrm{~mL}, 2.6 \mathrm{mmol}, 1 \mathrm{M}$ solution in THF) was added dropwise to a stirred solution of compound 3 (500 mg, $0.87 \mathrm{mmol})$ in dry THF (9 $\mathrm{mL}$ ) at ambient temperature under argon atmosphere. After the resulting reaction mixture was allowed to stir for $1 \mathrm{~h}$ at $60^{\circ} \mathrm{C}$ (as monitored by TLC analysis, Cyclohexane/ EtOAc 9:1; $\mathrm{R}_{f}$ $($ adduct $)=0.7 ; \mathrm{R}_{f(\text { product })}=0.3$; visualized with $1.3 \%$ ninhydrine), the solvent was removed under reduced pressure. The residue was subsequently partitioned between water $(50 \mathrm{~mL})$ and $\mathrm{CH}_{2} \mathrm{Cl}_{2}$ $(50 \mathrm{~mL})$, and the layers were separated. The aqueous layer was extracted several times with dichloromethane $(3 \times 40 \mathrm{~mL})$ and the combined organic layers were washed with saturated $\mathrm{NaHCO}_{3}$ solution $(100 \mathrm{~mL})$ and brine $(100 \mathrm{~mL})$, dried over anhydrous $\mathrm{Na}_{2} \mathrm{SO}_{4}$, filtered and concentrated in vacuo. Flash column chromatography of the resultant crude residue over silica gel using petroleum ether and ethylacetate as eluents (from $20-25 \%$ ethylacetate in petroleum ether) provided compound $\mathbf{4}$ as a colorless solid.

Yield: $355 \mathrm{mg}$, (89\%). Rf. 0.48 (cyclohexane / EtOAc 3:2, visualized with 1.3\% ninhydrine). ${ }^{1} \mathrm{H} \mathrm{NMR}\left(\mathrm{CDCl}_{3}, 500 \mathrm{MHz}, \mathrm{ppm}\right): \delta 4.95(\mathrm{~d}, J=8.6 \mathrm{~Hz}, 1 \mathrm{H}), 4.17(\mathrm{~m}, 1 \mathrm{H}), 3.86(\mathrm{~m}, 1 \mathrm{H}), 3.77$ $(\mathrm{m}, 1 \mathrm{H}), 3.69(\mathrm{~m}, 1 \mathrm{H}), 1.68-1.41(\mathrm{~m}, 14 \mathrm{H}), 1.36-1.22(\mathrm{~m}, 27 \mathrm{H}), 0.87(\mathrm{t}, J=6.9 \mathrm{~Hz}, 3 \mathrm{H}) .{ }^{13} \mathrm{C}-$ $\mathrm{NMR}\left(\mathrm{CDCl}_{3}, 125 \mathrm{MHz}, \mathrm{ppm}\right) \delta 108.2$, 78.0, 77.4, 63.9, 51.2, 32.1, 29.8, 29.8, 29.7, 29.6, 29.5, 29.3, 28.5, 27.7, 25.6, 25.4, 22.8, 14.3. ESI-MS $m / z(\mathrm{M}+\mathrm{Na})^{+} 480.3$.

\section{(S)-2-((tert-butoxycarbonyl)amino)-2-((4S,5R)-2,2-dimethyl-5-tetradecyl-1,3-dioxolan-4- yl)-ethyl methanesulfonate (5)}

To a stirred solution of compound $4(320 \mathrm{mg}, 0.7 \mathrm{mmol})$ in dry DCM $(7 \mathrm{~mL})$ at $0^{\circ} \mathrm{C}$ under argon atmosphere was added triethylamine $(0.55 \mathrm{ml}, 1.75 \mathrm{mmol})$, followed by dropwise addition of mesyl chloride $(82 \mu \mathrm{L}, 1.05 \mathrm{mmol})$ over a period of $20 \mathrm{~min}$. After being stirred at $40^{\circ} \mathrm{C}$ for $1 \mathrm{~h}$ (as indicated by TLC analysis for complete mesylation of adduct (cyclohexane/ EtOAc 3:2; $\mathrm{R}_{f \text { (adduct) }}=0.48 ; \mathrm{R}_{f}$ (product) $=0.67$; visualized with $1.3 \%$ ninhydrine), the reaction mixture was cooled to $0^{\circ} \mathrm{C}$, and was carefully quenched with saturated $\mathrm{NH}_{4} \mathrm{Cl}$ solution $(50 \mathrm{~mL})$. The resulting mixture was diluted with DCM $(50 \mathrm{~mL})$, and the layers were separated. The aqueous layer was extracted several times with dichloromethane $(3 \times 50 \mathrm{~mL})$, and the combined 
organic layers were washed with brine $(100 \mathrm{~mL})$, dried over anhydrous $\mathrm{Na}_{2} \mathrm{SO}_{4}$, filtered and concentrated under reduced pressure. The obtained crude mixture was immediately purified by flash column chromatography over silica gel using petroleum ether and ethylacetate as eluents (from $10-15 \%$ ethylacetate in petroleum ether) to provide the desired product $\mathbf{5}$ as pale yellow solid. The product was used immediately in the next step.

Yield: $350 \mathrm{mg}$, (93\%). Rf: 0.51 (cyclohexane / EtOAc 4:1, visualized with 1.3\% ninhydrine). ESI-MS $m / z(\mathrm{M}+\mathrm{Na})^{+}$558.2.

tert-Butyl ((S)-1-((4S,5R)-2,2-dimethyl-5-tetradecyl-1,3-dioxolan-4-yl)ethyl)-carbamate (6)

To a stirred solution of compound $5(310 \mathrm{mg}, 0.58 \mathrm{mmol})$ in dry THF $(6 \mathrm{~mL})$ at $-15^{\circ} \mathrm{C}$ under argon atmosphere was added lithium aluminum hydride (LAH, $26.5 \mathrm{mg}, 0.7 \mathrm{mmol}$ ) in portions over a period of $20 \mathrm{~min}$. After the reaction mixture was allowed to stir at the same conditions for $1 \mathrm{~h}$ (as monitored by TLC analysis, cyclohexane/EtOAc $4: 1 ; \mathrm{R}_{f(\text { adduct })}=0.51 ; \mathrm{R}_{f(\text { product })}=0.63$; visualized with $0.3 \%$ ninhydrine), an ice-cooled $10 \%$ aqueous potassium hydroxide solution (2 $\mathrm{mL}$ ) was carefully added to quench. After the resulting mixture was stirred at ambient temperature for $1 \mathrm{~h}$, the white precipitate was removed by filtration through celite. The combined organic filtrates were washed with aqueous phosphate buffer $(\mathrm{pH}=7,50 \mathrm{~mL})$ and brine $(50 \mathrm{~mL})$, dried over anhydrous $\mathrm{Na}_{2} \mathrm{SO}_{4}$, filtered and concentrated under reduced pressure. Purification of the resultant residue by flash column chromatography over silica gel using petroleum ether and ethylacetate as eluents (from 5\%-15\% ethylacetate in petroleum ether) afforded the desired product $\mathbf{6}$ as colorless solid.

Yield: $210 \mathrm{mg}$, (82\%). $\mathrm{R}_{f}: 0.63$ (cyclohexane / EtOAc 4:1, visualized with 1.3\% ninhydrine). ${ }^{1} \mathrm{H} \mathrm{NMR}\left(\mathrm{CDCl}_{3}, 500 \mathrm{MHz}, \mathrm{ppm}\right): \delta 4.53(\mathrm{~d}, J=8.9 \mathrm{~Hz}, 1 \mathrm{H}), 4.14(\mathrm{dd}, J=12.9,6.4 \mathrm{~Hz}, 1 \mathrm{H})$, $3.98(\mathrm{t}, J=5.4 \mathrm{~Hz}, 1 \mathrm{H}), 3.75(\mathrm{~m}, 1 \mathrm{H}), 1.60-1.41(\mathrm{~m}, 14 \mathrm{H}), 1.34-1.24(\mathrm{~m}, 27 \mathrm{H}), 1.15(\mathrm{~d}, J=$ $6.6 \mathrm{~Hz}, 3 \mathrm{H}), 0.88(\mathrm{t}, J=6.9 \mathrm{~Hz}, 3 \mathrm{H}) .{ }^{13} \mathrm{C}-\mathrm{NMR}\left(\mathrm{CDCl}_{3}, 125 \mathrm{MHz}, \mathrm{ppm}\right) \delta 155.1,107.9,80.6$, 79.4 , 77.9, 46.6, 32.1, 29.8, 29.8, 29.7, 29.5, 28.5, 25.5, 22.8, 18.0, 14.3. ESI-MS $m / z(\mathrm{M}+\mathrm{H})^{+}$ 442.3 .

\section{(2S,3S,4R)-2-aminooctadecane-3,4-diol (7)}

A stirred solution of compound $6(140 \mathrm{mg}, 0.32 \mathrm{mmol})$ in methanol $(5 \mathrm{~mL})$ at $0^{\circ} \mathrm{C}$ was treated with acetyl chloride in dropwise $(\mathrm{AcCl}, 230 \mu \mathrm{L}, 3.2 \mathrm{mmol})$. After the resulting reaction mixture was allowed to stir at ambient temperature for $2 \mathrm{~h}$, the resultant white solid was filtered off and subsequently washed with ice-cooled diethylether to provide the desired product as a colorless solid. The obtained crude product was further purified by flash column chromatography over silica gel using ethylacetate and isopropanol as eluents (from $0-10 \%$ isopropanol in ethylacetate) to afford compound $\mathbf{7}$ as a white solid.

Yield: $65 \mathrm{mg}(69 \%) . \mathrm{R}_{f}$. 0.38 (EtOAc/ iso-propanol 4:1, visualized with $\mathrm{KMnO}_{4}$ solution). ${ }^{1} \mathrm{H}$ NMR (MeOD, $500 \mathrm{MHz}, \mathrm{ppm}) \delta 3.58$ (dt, $J=9.5,4.7 \mathrm{~Hz}, 1 \mathrm{H}), 3.40$ (ddd, $J=16.9,11.8,5.9$ $\mathrm{Hz}, 1 \mathrm{H}), 1.82(\mathrm{t}, J=9.5 \mathrm{~Hz}, 1 \mathrm{H}), 1.60-1.52(\mathrm{~m}, 1 \mathrm{H}), 1.40-1.26(\mathrm{~m}, 8 \mathrm{H}), 1.25(\mathrm{~d}, J=6.7 \mathrm{~Hz}$, $1 \mathrm{H}), 0.89$ (t, $J=6.8 \mathrm{~Hz}, 1 \mathrm{H}) .{ }^{13} \mathrm{C} \mathrm{NMR}(\mathrm{MeOD}, 125 \mathrm{MHz}, \mathrm{ppm}) \delta 74.7,72.8,50.4,35.3,33.1$, $30.8,30.8,30.7,30.5,26.3,23.7,14.4,11.9$. ESI-MS $m / z(\mathrm{M}+\mathrm{H})^{+} 302.3$. 


\section{Synthesis of (tert-butoxycarbonyl)-L-alanine (8)}

A solution of di-tert-butyl dicarbonate $(14.34 \mathrm{~g}, 70.72 \mathrm{mmol})$ in dioxane $(120 \mathrm{~mL})$ was added dropwise to a stirred solution of L-alanine $(6.00 \mathrm{~g}, 67.34 \mathrm{mmol})$ in aqueous $1 \mathrm{M} \mathrm{NaOH}(120$ $\mathrm{mL}$ ) at $-10^{\circ} \mathrm{C}$. After the resulting reaction mixture was stirred for $12 \mathrm{~h}$ at ambient temperature, the reaction mixture was washed with ethylacetate $(2 \times 150 \mathrm{~mL})$ to remove excess of unreacted $\mathrm{Boc}_{2} \mathrm{O}$. The aqueous layer was cooled again at $-15^{\circ} \mathrm{C}$ and carefully acidified with a solution of $1 \mathrm{M} \mathrm{KHSO}_{4}$ to $\mathrm{pH}=2-3$. The resulting mixture was subsequently extracted several times with ethylacetate $(4 \times 150 \mathrm{~mL})$. The organic layers were combined, dried over anhydrous $\mathrm{Na}_{2} \mathrm{SO}_{4}$, filtered and concentrated in vacuo to provide $N$-Boc-L-alanine as white solid. The product was used in the next step without further purification.

Yield: $11.4 \mathrm{~g}(87 \%)$. $\mathrm{R}_{f}$ : $0.3\left(\mathrm{CHCl}_{3} / \mathrm{MeOH} 12: 1\right.$; visualized with $1.3 \%$ ninhydrine solution). ${ }^{1} \mathrm{H} \mathrm{NMR}\left(\mathrm{CDCl}_{3}, 500 \mathrm{MHz}, \mathrm{ppm}\right): \delta$ 5.12-5.04 (m, 1H), 4.40-4.32 (m, 1H), 1.48-1.43 (m, 12H). ${ }^{13} \mathrm{C} \mathrm{NMR}\left(\mathrm{CDCl}_{3}, 126 \mathrm{MHz}, \mathrm{ppm}\right): \delta 177.83,155.62,80.46,49.25,28.43,18.43$. ESI-LCMS: $m / z$ calcd for $\mathrm{C}_{8} \mathrm{H}_{16} \mathrm{NO}_{4}[\mathrm{M}+\mathrm{H}]^{+}$190.11; observed 190.1 [31].

\section{Synthesis of (S)-tert-butyl-1-( $N$-methoxy- $N$-methylcarbamoyl)ethylcarbamate (9)}

To a stirred solution of $N$-Boc-L-alanine $(4.50 \mathrm{~g}, 23.8 \mathrm{mmol}), \mathrm{N}, O$-dimethylhydroxylamine hydrochloride $(2.6 \mathrm{~g}, 26.2 \mathrm{mmol})$ and $N$-methylmorpholine $(5.2 \mathrm{~mL}, 47.6 \mathrm{mmol})$ in dry DCM $(100 \mathrm{~mL})$ at $-10^{\circ} \mathrm{C}$ under an argon atmosphere, 1-ethyl-3-(3dimethylaminopropyl)carbodiimide hydrochloride (5 g, $26.2 \mathrm{mmol}$ ) was added portionwise over a period of $30 \mathrm{~min}$. The resulting reaction mixture was allowed to stir for $4 \mathrm{~h}$ at $0^{\circ} \mathrm{C}$ (as monitored by TLC analysis for almost complete reaction; Silica gel, EtOAc $100 \%$; $\mathrm{R}_{f(a d d u c t}=$ $0.1 ; \mathrm{R}_{f(\text { product })}=0.56$; visualized with $1.3 \%$ ninhydrine solution), and was then quenched with saturated $\mathrm{NH}_{4} \mathrm{Cl}$ solution $(200 \mathrm{~mL})$. The layers were separated and the aqueous layer was extracted several times with $\mathrm{CH}_{2} \mathrm{Cl}_{2}(4 \times 100 \mathrm{~mL})$. The organic layers were combined, washed with saturated $\mathrm{NaHCO}_{3}$ solution $(120 \mathrm{~mL})$, brine $(120 \mathrm{~mL})$, dried over anhydrous $\mathrm{Na}_{2} \mathrm{SO}_{4}$, filtered and concentrated under reduced pressure to afford compound $\mathbf{9}$ as a white solid. The product was used in the next step without any further purification.

Yield: $4.1 \mathrm{~g}(76 \%)$. $\mathrm{R}_{f}: 0.42$ (cyclohexane/ethylacetate $3: 2$, visualized with $1.3 \%$ ninhydrine). ${ }^{1} \mathrm{H} \mathrm{NMR}\left(\mathrm{CDCl}_{3}, 500 \mathrm{MHz}, \mathrm{ppm}\right): \delta 5.27$ (d, J=6.9 Hz, 1H), 4.74-4.62 (br. m, 1H), 3.77 (s, $3 \mathrm{H}), 3.21(\mathrm{~s}, 3 \mathrm{H}), 1.44(\mathrm{~s}, 9 \mathrm{H}), 1.31(\mathrm{~d}, J=6.9 \mathrm{~Hz}, 3 \mathrm{H}) .{ }^{13} \mathrm{C} \mathrm{NMR}\left(\mathrm{CDCl}_{3}, 126 \mathrm{MHz}, \mathrm{ppm}\right): \delta$ 18.80, 28.50, 32.27, 46.66, 61.75, 79.65, 155.33, 173.80. ESI-LCMS: $m / z$ calcd for $\mathrm{C}_{10} \mathrm{H}_{21} \mathrm{~N}_{2} \mathrm{O}_{4}$ $[\mathrm{M}+\mathrm{H}]^{+}$233.15; observed $233.1[31]$.

\section{Synthesis of (S)-tert-butyl -(3-oxohex-5-en-2-yl)carbamate (10)}

The 1-allylmagnesium bromide was prepared as follows; Catalytic drops of 1,2-dibromoethane was added to a mixture of magnesium powder $(1.84 \mathrm{~g}, 77 \mathrm{mmol})$ in anhydrous $\mathrm{Et}_{2} \mathrm{O}(10 \mathrm{~mL})$ under an argon atmosphere at ambient temperature. The resulting mixture was stirred at the same conditions for $10 \mathrm{~min}$, before it treated with a solution of 1-allylbromide $(2.4 \mathrm{~g}, 19.3$ mmol, $1 \mathrm{M}$ solution in anhydrous $\mathrm{Et}_{2} \mathrm{O}$ ). The resulting reaction mixture was allowed to stir at $35^{\circ} \mathrm{C}$ for $3 \mathrm{~h}$ to afford a transparent allylmagnesium bromide solution which was used in the next step. 
A freshly prepared allylmagnesium bromide solution $(19.3 \mathrm{mmol}, 20 \mathrm{~mL})$ was added dropwise to a stirred solution of Weinreb amide $9(1.3 \mathrm{~g}, 5.5 \mathrm{mmol})$ in dry diethylether $(\mathrm{mL})$ under argon atmosphere at $0^{\circ} \mathrm{C}$. After being stirred at the same conditions for $30 \mathrm{~min}$ and for additional $2 \mathrm{~h}$ at ambient temperature (as judged by TLC analysis; Pet. ether/ EtOAc 4:1; $\mathrm{R}_{f \text { (adduct) }}=0.2 ; \mathrm{R}_{f}$ (product $)=0.54$; visualized with $1.3 \%$ ninhydrine), the reaction mixture was dropwisely added to an ice-cooled $1 \mathrm{M} \mathrm{HCl}$ solution $(100 \mathrm{~mL})$ to quench. The resulting mixture was diluted with ethylactetate and transferred to separating funnel. The layers were separated and the aqueous layer was extracted again with ethylacetate $(2 \times 100 \mathrm{~mL})$. The organic extracts were combined, washed with sat $\mathrm{NaHCO}_{3}$ solution and brine solution, dried over anhydrous $\mathrm{Na}_{2} \mathrm{SO}_{4}$, filtered and concentrated in vacuo to provide a brownish oil residue. Purification of the resultant crude residue with flash column chromatography over silica gel using petroleum ether and ethylacetate as eluents (0-10\% ethylacetate in petroleum ether) afforded the product $\mathbf{1 0}$ as a white solid.

Yield: $710 \mathrm{mg}(61 \%)$. $\mathrm{R}_{f}$. 0.54 (Pet. ether /EtOAc 4:1, visualized with $1.3 \%$ ninhydrine solution). ${ }^{1} \mathrm{H} \mathrm{NMR}\left(\mathrm{CDCl}_{3}, 500 \mathrm{MHz}, \mathrm{ppm}\right) \delta 5.91$ (ddt, $\left.J=17.1,10.2,6.9 \mathrm{~Hz}, 1 \mathrm{H}\right), 5.20$ (ddd, $J=10.2,2.7,1.3 \mathrm{~Hz}, 1 \mathrm{H}), 5.16(\mathrm{dq}, J=17.1,1.5 \mathrm{~Hz}, 1 \mathrm{H}), 4.39-4.32(\mathrm{~m}, 1 \mathrm{H}), 3.33-3.22(\mathrm{~m}$, $2 \mathrm{H}), 1.43(\mathrm{~s}, 9 \mathrm{H}), 1.33(\mathrm{~d}, J=7.2 \mathrm{~Hz}, 3 \mathrm{H}) .{ }^{13} \mathrm{C} \mathrm{NMR}\left(\mathrm{CDCl}_{3}, 126 \mathrm{MHz}, \mathrm{ppm}\right) \delta 207.55,155.28$, 129.94, 119.45, 79.94, 54.91, 44.14, 28.47, 17.83. ESI-MS $m / z$ calcd for $\mathrm{C}_{11} \mathrm{H}_{20} \mathrm{NO}_{3}[\mathrm{M}+\mathrm{H}]^{+}$ 214.14; observed: 214.1 .

\section{Synthesis of (2S,3R)-tert-butyl (3-hydroxyhex-5-en-2-yl)carbamate (11)}

Lithium tri-(tert-butoxy)-aluminum hydride $(1.7 \mathrm{~g}, 6.75 \mathrm{mmol})$ was added in portionwise to a stirred solution of compound $10(0.58 \mathrm{~g}, 2.7 \mathrm{mmol})$ in dry ethanol $(6 \mathrm{~mL})$ under argon atmosphere at $-78^{\circ} \mathrm{C}$. The resulting reaction mixture was allowed to stir at the same conditions for $2 \mathrm{~h}$ (as judged by TLC analysis; Pet. ether/ EtOAc 4:1; $\mathrm{R}_{f}$ (adduct) $=0.54 ; \mathrm{R}_{f}$ (product) $=0.42$; visualized with $1.3 \%$ ninhydrine), before it was quenched with ice-cooled $1 \mathrm{M} \mathrm{HCl}$ solution $(120 \mathrm{~mL})$. The resulting mixture was allowed to warm gradually to ambient temperature and then diluted with ethylacetate $(100 \mathrm{~mL})$. The layers were separated and the aqueous layer was extracted with ethylacetate $(2 \times 100 \mathrm{~mL})$. The combined organic extracts were washed with sat. $\mathrm{NaHCO}_{3}$ solution and brine solution, dried over anhydrous $\mathrm{Na}_{2} \mathrm{SO}_{4}$, filtered and concentrated under reduced pressure. The obtained crude residue was purified by flash column chromatography over silica gel using petroleum ether and ethylacetate as eluents (10$20 \%$ ethylacetate in petroleum ether) to provide the product $\mathbf{1 1}$ as a pale yellow oil.

Yield: $470 \mathrm{mg}(81 \%)$. Rf. 0.48 (Pet. ether /EtOAc 3:2, visualized with 1.3\% ninhydrine solution). ${ }^{1} \mathrm{H}$ NMR $\left(\mathrm{CDCl}_{3}, 500 \mathrm{MHz}, \mathrm{ppm}\right) \delta 5.83$ (ddt, $\left.J=17.1,10.2,7.1 \mathrm{~Hz}, 1 \mathrm{H}\right), 5.17-$ $5.13(\mathrm{~m}, 1 \mathrm{H}), 5.12$ (dd, $J=3.3,1.5 \mathrm{~Hz}, 1 \mathrm{H}), 4.78$ (br.s, $1 \mathrm{H}), 3.73-3.67(\mathrm{~m}, 2 \mathrm{H}), 2.27-2.12$ $(\mathrm{m}, 2 \mathrm{H}), 1.44(\mathrm{~s}, 9 \mathrm{H}), 1.11(\mathrm{~d}, J=6.8 \mathrm{~Hz}, 3 \mathrm{H}) .{ }^{13} \mathrm{C} \mathrm{NMR}\left(\mathrm{CDCl}_{3}, 126 \mathrm{MHz}, \mathrm{ppm}\right) \delta 155.92$, $134.83,118.22,79.65,73.45,50.42,38.45,28.54,14.74$. ESI-MS $m / z$ calcd for $\mathrm{C}_{11} \mathrm{H}_{22} \mathrm{NO}_{3}$ $[\mathrm{M}+\mathrm{H}]^{+}$216.16; observed: 214.2 .

\section{Synthesis of $(2 S, 3 R, E)$-tert-butyl (-3-hydroxyoctadec-5-en-2-yl)carbamate (12)}

To a stirred solution of compound $11(210 \mathrm{mg}, 1 \mathrm{mmol})$ and 1-tetradecene $(0.8 \mathrm{~g}, 4 \mathrm{mmol})$ in dry d-chloroform $(5 \mathrm{~mL})$ under argon atmosphere at ambient temperature was added a catalytic amount of $p$-benzoquinone $(10 \mathrm{~mol} \%)$ followed by a catalytic amount of Grubbs catalyst $2^{\text {nd }}$ 
generation (10 mol\%). The resulting reaction mixture was allowed to stir under reflux for $12 \mathrm{~h}$ (as monitored by TLC analysis, no change in the composition of reaction mixture, Pet. ether/ EtOAc $4: 1 ; \mathrm{R}_{f}$ (adduct) $=0.42 ; \mathrm{R}_{f \text { (product) }}=0.56$; visualized with $1.3 \%$ ninhydrine). The mixture was concentrated under reduced pressure and the resultant residue was purified by flash column chromatography over silica gel using petroleum ether and ethylacetate as eluents (0-10\% ethylacetate in petroleum ether) to provide the desired product $\mathbf{1 2}$ as colorless oil.

Yield: $210 \mathrm{mg}(56 \%)$. Rf: 0.56 (Pet. ether /EtOAc 4:1, visualized with $1.3 \%$ ninhydrine solution). ${ }^{1} \mathrm{H}$ NMR $\left(\mathrm{CDCl}_{3}, 500 \mathrm{MHz}, \mathrm{ppm}\right) \delta 5.55(\mathrm{dt}, J=13.6,6.7 \mathrm{~Hz}, 1 \mathrm{H}), 5.44-5.37$ (m, 1H), 4.78 (br.s, 1H), $3.74-3.65(\mathrm{~m}, 1 \mathrm{H}), 3.65-3.60(\mathrm{~m}, 1 \mathrm{H}), 2.22-2.15(\mathrm{~m}, 1 \mathrm{H}), 2.09$ (dd, $J$ $=15.0,7.2 \mathrm{~Hz}, 1 \mathrm{H}), 2.00(\mathrm{dd}, J=14.4,7.2 \mathrm{~Hz}, 2 \mathrm{H}), 1.44(\mathrm{~s}, 9 \mathrm{H}), 1.37-1.24(\mathrm{~m}, 20 \mathrm{H}), 1.10$ $(\mathrm{d}, J=6.8 \mathrm{~Hz}, 3 \mathrm{H}), 0.88(\mathrm{t}, J=7.0 \mathrm{~Hz}, 3 \mathrm{H}) .{ }^{13} \mathrm{C} \mathrm{NMR}\left(\mathrm{CDCl}_{3}, 126 \mathrm{MHz}, \mathrm{ppm}\right) \delta 155.71,134.83$, 125.53, 79.37, 73.48, 50.15, 37.25, 32.66, 31.93, 29.68, 29.65, 29.63, 29.51, 29.44, 29.36, 29.23, 28.42, 22.69, 14.12. ESI-MS $m / z$ calcd for $\mathrm{C}_{23} \mathrm{H}_{45} \mathrm{NO}_{3} \mathrm{Na}[\mathrm{M}+\mathrm{Na}]^{+} 406.33$; observed: 406.3.

\section{Synthesis of $(2 S, 3 R, E)-2$-aminooctadec-5-en-3-ol (13)}

To a stirred solution of compound $12(135 \mathrm{mg}, 0.36 \mathrm{mmol})$ in dry methanol $(4 \mathrm{~mL})$ at $0^{\circ} \mathrm{C}$ was added dropwise acetyl chloride $(260 \mu \mathrm{L}, 3.6 \mathrm{mmol})$ over a period of $10 \mathrm{~min}$. After being stirred at the same conditions for $30 \mathrm{~min}$ and for additional $2 \mathrm{~h}$ at ambient temperature (as indicated by TLC analysis for complete deprotection), the mixture was concentrated in vacuo. The residue was diluted with diethylether and washed with sat. $\mathrm{NaHCO}_{3}$ solution. The aqueous layer was extracted again with diethylether and the combined organic layers were washed with brine, dried over anhydrous $\mathrm{Na}_{2} \mathrm{SO}_{4}$, filtered and concentrated under reduced pressure. The obtained residue was purified by flash column chromatography over silica gel using isopropanol and ethylacetate as eluents (0-10\% isopropanol in ethylacetate) to afford the pure product $\mathbf{1 3}$ as a white waxy-white solid.

Yield: $64 \mathrm{mg}$ (63\%). $\mathrm{R}_{f} 0.45$ (EtOAc/ iso-propanol 4:1, visualized with $1.3 \%$ ninhydrine). ${ }^{1} \mathrm{H}$ NMR (MeOD, $500 \mathrm{MHz}, \mathrm{ppm}) \delta 5.58(\mathrm{dd}, J=14.3,7.5 \mathrm{~Hz}, 1 \mathrm{H}), 5.44$ (dd, $J=14.6,7.2 \mathrm{~Hz}$, $1 \mathrm{H}), 3.78-3.72(\mathrm{~m}, 1 \mathrm{H}), 3.26(\mathrm{dd}, J=6.7,2.8 \mathrm{~Hz}, 1 \mathrm{H}), 2.29-2.13(\mathrm{~m}, 2 \mathrm{H}), 2.03(\mathrm{dd}, J=13.3$, $6.6 \mathrm{~Hz}, 2 \mathrm{H}), 1.42-1.27(\mathrm{~m}, 20 \mathrm{H}), 1.23(\mathrm{~d}, J=6.8 \mathrm{~Hz}, 3 \mathrm{H}), 0.90(\mathrm{t}, J=6.7 \mathrm{~Hz}, 3 \mathrm{H}) .{ }^{13} \mathrm{C} \mathrm{NMR}$ (MeOD, $126 \mathrm{MHz}, \mathrm{ppm}) \delta$ 135.37, 126.18, 71.69, 51.92, 37.68, 33.67, 33.04, 30.78, 30.70, 30.59, 30.43, 30.37, 23.77, 14.48, 11.62. ESI-MS: $m / z$ calcd for $\mathrm{C}_{18} \mathrm{H}_{38} \mathrm{NO}[\mathrm{M}+\mathrm{H}]^{+} 284.29$; observed 284.3.

\section{Synthesis of (S)-tert-butyl-(3-oxohept-6-en-2-yl)carbamate (14)}

The 1-butylmagnesium bromide solution was prepared as follows, A magnesium powder (510 $\mathrm{mg}, 21.2 \mathrm{mmol}$ ) was suspended in dry diethylether $(2 \mathrm{~mL})$ at ambient temperature under argon atmosphere and the resulting mixture was subsequently treated with drops of 1,2-diromoethane. The resulting mixture was allowed to stir at the same conditions for $10 \mathrm{~min}$ and then a solution of 4-bromobutene $(0.71 \mathrm{~g}, 5.3 \mathrm{mmol}, 1 \mathrm{M}$ in dry diethylether) was dropwisely added over a period of $10 \mathrm{~min}$. The resulting reaction mixture was allowed to stir at $35^{\circ} \mathrm{C}$ for $1 \mathrm{~h}$ to afford a 
transparent solution of 1-butylmagnesium bromide. The solution was used directly in the next step.

To a stirred solution of Weinreb amide $9(0.34 \mathrm{~g}, 1.5 \mathrm{mmol})$ in dry diethylether $(15 \mathrm{~mL})$ under argon atmosphere at $0^{\circ} \mathrm{C}$ was added dropwise a fresh solution of 1-butylmagnesium bromide (5.3 mmol, $1 \mathrm{M}$ in diethylether) over a period of $20 \mathrm{~min}$. The resulting reaction mixture was allowed to stir at the same conditions for $30 \mathrm{~min}$ and for additional $2 \mathrm{~h}$ at ambient temperature (as monitored by TLC analysis; Pet. ether / EtOAc 4:1; $\mathrm{R}_{f \text { (adduct) }}=0.2 ; \mathrm{R}_{f \text { (product) }}=0.55$; visualized with $1.3 \%$ ninhydrine solution). The reaction was diluted with diethylether $(100 \mathrm{~mL})$ and subsequently quenched with an ice-cold $1 \mathrm{M} \mathrm{HCl}(100 \mathrm{~mL})$. The layers were separated and the aqueous layer was extracted with diethylether $(2 \mathrm{x} 80 \mathrm{~mL})$. The organic layers were combined, washed with sat. $\mathrm{NaHCO}_{3}$ solution and brine, dried over anhydrous $\mathrm{Na}_{2} \mathrm{SO}_{4}$, filtered, and concentrated in vacuo. Purification of the obtained residue by flash column chromatography over silica gel using petroleum ether and ethylacetate as eluents (10-15\% ethylacetate in petroleum ether) afforded the desired product $\mathbf{1 4}$ as a white solid.

Yield: $210 \mathrm{mg}(71 \%)$. R $\mathrm{R}_{f} 0.55$ (Pet. ether /EtOAc 4:1, visualized with $1.3 \%$ ninhydrine solution). ${ }^{1} \mathrm{H} \mathrm{NMR}\left(\mathrm{CDCl}_{3}, 500 \mathrm{MHz}, \mathrm{ppm}\right) \delta 5.79$ (ddt, $\left.J=16.8,10.2,6.5 \mathrm{~Hz}, 1 \mathrm{H}\right), 5.24$ (br.s, $1 \mathrm{H}), 5.03(\mathrm{ddd}, J=17.1,3.2,1.6 \mathrm{~Hz}, 1 \mathrm{H}), 4.98(\mathrm{dd}, J=10.2,1.4 \mathrm{~Hz}, 1 \mathrm{H}), 4.31$ (p, $J=7.0 \mathrm{~Hz}$, $1 \mathrm{H}), 2.63(\mathrm{dt}, J=17.2,7.5 \mathrm{~Hz}, 1 \mathrm{H}), 2.59-2.52(\mathrm{~m}, 1 \mathrm{H}), 2.35(\mathrm{dt}, J=14.0,4.3 \mathrm{~Hz}, 2 \mathrm{H}), 1.43$ $(\mathrm{s}, 9 \mathrm{H}), 1.32(\mathrm{~d}, J=7.2 \mathrm{~Hz}, 3 \mathrm{H}) .{ }^{13} \mathrm{C} \mathrm{NMR}\left(\mathrm{CDCl}_{3}, 126 \mathrm{MHz}, \mathrm{ppm}\right) \delta 208.97,155.32,136.88$, $115.68,79.86,55.22,38.41,28.47,27.60,17.96$. ESI-MS $m / z$ calcd for $\mathrm{C}_{12} \mathrm{H}_{22} \mathrm{NO}_{3}[\mathrm{M}+\mathrm{H}]^{+}$ 228.16; observed: 228.2 .

\section{Synthesis of $(S, E)$-tert-butyl -(3-oxooctadec-6-en-2-yl)carbamate (15)}

A stirred solution of compound $14(110 \mathrm{mg}, 0.47 \mathrm{mmol})$ and 1-tridecene $(0.34 \mathrm{~g}, 1.9 \mathrm{mmol})$ in dry d-chloroform $(4 \mathrm{~mL})$ under argon atmosphere at ambient temperature was treated a catalytic amount of $p$-benzoquinone $(10 \mathrm{~mol} \%)$ followed by a catalytic amount of Grubbs catalyst $2^{\text {nd }}$ generation $(8 \mathrm{~mol} \%)$. After the resulting reaction mixture was stirred under reflux for $6 \mathrm{~h}$ (as monitored by TLC analysis; no further change in the composition of the reaction mixture; Pet. ether/ EtOAc 4:1; $\mathrm{R}_{f \text { (adduct) }}=0.55 ; \mathrm{R}_{f}$ (product) $=0.68$; visualized with $1.3 \%$ ninhydrine), the solvent was removed under reduced pressure. The obtained residue was subjected to flash column chromatography over silica gel using petroleum ether and ethylacetate as eluents (0-10\% ethylacetate in petroleum ether) to afford the desired product $\mathbf{1 5}$ as a waxy-white solid.

Yield: $95 \mathrm{mg}(53 \%) . \mathrm{R}_{f}$. 0.47 (Pet. ether /EtOAc 9:1, visualized with 1.3\% ninhydrine solution). ${ }^{1} \mathrm{H} \mathrm{NMR}\left(\mathrm{CDCl}_{3}, 500 \mathrm{MHz}, \mathrm{ppm}\right) \delta 5.52-5.34(\mathrm{~m}, 1 \mathrm{H}), 5.33-5.25(\mathrm{~m}, 1 \mathrm{H}), 5.20$ (br.s, $1 \mathrm{H}), 4.35-4.20(\mathrm{~m}, 1 \mathrm{H}), 2.59-2.41(\mathrm{~m}, 1 \mathrm{H}), 2.28-2.18(\mathrm{~m}, 1 \mathrm{H}), 1.99-1.84(\mathrm{~m}, 4 \mathrm{H})$, $1.37(\mathrm{~s}, 9 \mathrm{H}), 1.30-1.17(\mathrm{~m}, 21 \mathrm{H}), 0.81(\mathrm{t}, J=7.0 \mathrm{~Hz}, 3 \mathrm{H}) .{ }^{13} \mathrm{C} \mathrm{NMR}\left(\mathrm{CDCl}_{3}, 126 \mathrm{MHz}, \mathrm{ppm}\right)$ $\delta$ 209.09, 155.20, 132.01, 127.85, 79.69, 55.09, 39.17, 32.51, 31.93, 29.64, 29.52, 29.45, 29.36, 29.18, 28.35, 26.56, 22.70, 17.87, 14.13. ESI-MS $m / z$ calcd for $\mathrm{C}_{23} \mathrm{H}_{43} \mathrm{NO}_{3} \mathrm{Na}[\mathrm{M}+\mathrm{Na}]^{+} 404.31$; observed: 404.3 .

\section{Synthesis of $(S, E)$-2-aminooctadec-6-en-3-one (16)}

To a stirred solution of compound $15(77 \mathrm{mg}, 0.2 \mathrm{mmol})$ in absolute methanol $(2 \mathrm{~mL})$ at $0^{\circ} \mathrm{C}$ was dropwisely added acetylchloride $(143 \mu \mathrm{L}, 2 \mathrm{mmol})$ over a period of $10 \mathrm{~min}$. The resulting 
reaction mixture was allowed to stir at the same conditions for $30 \mathrm{~min}$, gradually warm to ambient temperature, and stirred for additional $2 \mathrm{~h}$; during while a white solid formed. The mixture was filtered and the residue was washed several times with ice-cooled diethylether to afford a white waxy-solid of crude product. The obtained crude product was further purified by flash column chromatography over silica gel using ethylacetate and isopropanol as eluents (010\% isopropanol in ethylacetate) to provide the final pure product $\mathbf{1 6}$ as a white solid.

Yield: $38 \mathrm{mg}$ (67\%). $\mathrm{R}_{f}$ : 0.51 (EtOAc/iso-propanol 4:1, visualized with $\mathrm{KMnO}_{4}$ solution). ${ }^{1} \mathrm{H}$ NMR (MeOD, $500 \mathrm{MHz}, \mathrm{ppm}) \delta 5.55-5.47(\mathrm{~m}, 1 \mathrm{H}), 5.45-5.39(\mathrm{~m}, 1 \mathrm{H}), 4.14(\mathrm{q}, J=7.3 \mathrm{~Hz}$, $1 \mathrm{H}), 2.76-2.69(\mathrm{~m}, 1 \mathrm{H}), 2.66-2.58(\mathrm{~m}, 1 \mathrm{H}), 2.35-2.27(\mathrm{~m}, 2 \mathrm{H}), 1.98(\mathrm{q}, J=6.6 \mathrm{~Hz}, 2 \mathrm{H})$, $1.53-1.49(\mathrm{~m}, 4 \mathrm{H}), 1.37-1.27(\mathrm{~m}, 17 \mathrm{H}), 0.90(\mathrm{t}, J=7.0 \mathrm{~Hz}, 3 \mathrm{H}) .{ }^{13} \mathrm{C}$ NMR $(\mathrm{MeOD}, 126$ $\mathrm{MHz}, \mathrm{ppm}) \delta 206.76,133.10,129.15,55.86,39.32$, 33.57, 33.07, 30.78, 30.74, 30.60, 30.46, 30.27, 27.21, 23.73, 15.66, 14.43. ESI-MS: $m / z$ calcd for $\mathrm{C}_{11} \mathrm{H}_{36} \mathrm{NO}[\mathrm{M}+\mathrm{H}]^{+} 282.28$; observed 282.3 .

\section{Synthesis of (S)-tert-butyl-(3-oxooctadecan-2-yl)carbamate (17)}

The 1-pentadecylmagnesium bromide solution was synthesized as follows; A mixture of magnesium turnings $(0.51 \mathrm{~g}, 21 \mathrm{mmol})$ in anhydrous THF $(4 \mathrm{~mL})$ under an argon atmosphere at ambient temperature was treated with drops of 1,2-dibromoethane. The resulting mixture was allowed to stir at the same conditions for $20 \mathrm{~min}$, before it was treated dropwisely with a solution of 1-bromopentadecane (1.5 g, $5.2 \mathrm{mmol}$, in $2 \mathrm{~mL}$ of anhydrous THF) over a period of $20 \mathrm{~min}$. The resulting reaction mixture was allowed to stir for additional $3 \mathrm{~h}$ at $35^{\circ} \mathrm{C}$ to afford a transparent solution of 1-pentadecylmagnesium bromide which was immediately used in the next step.

A stirred solution of Weinreb amide derivative $9(0.35 \mathrm{~g}, 1.5 \mathrm{mmol})$ in anhydrous THF $(15 \mathrm{~mL})$ under an argon atmosphere at $0^{\circ} \mathrm{C}$ was treated dropwisely with a freshly prepared 1pentadecylmagnesium bromide solution $\left(6 \mathrm{~mL}, 5.1 \mathrm{mmol}, 1 \mathrm{M}\right.$ solution in $\left.\mathrm{Et}_{2} \mathrm{O}\right)$ over a period of $10 \mathrm{~min}$. After being stirred at ambient temperature for $2 \mathrm{~h}$ (as monitored by TLC analysis; Pet. ether / EtOAc 4:1; $\mathrm{R}_{f}$ (adduct) $=0.2 ; \mathrm{R}_{f}$ (product) $=0.69$; visualized with $1.3 \%$ ninhydrine solution), the reaction mixture was cooled again to $0^{\circ} \mathrm{C}$ and subsequently quenched with an icecold $1 \mathrm{M} \mathrm{HCl}$ solution $(40 \mathrm{~mL})$. The resulting mixture was diluted with diethylether $(50 \mathrm{~mL})$, and the layer were separated. The aqueous layer was extracted with diethylether $(3 \times 50 \mathrm{~mL})$, and the combined organic phases were washed with saturated $\mathrm{NaHCO}_{3}$ solution $(80 \mathrm{~mL})$ and brine $(80 \mathrm{~mL})$, dried over anhydrous $\mathrm{Na}_{2} \mathrm{SO}_{4}$, filtered and concentrated under reduced pressure. The resultant crude product was purified by flash column chromatography over silica gel using petroleum ether and ethylacetate as eluents (from 5-15\% ethylacetate in petroleum ether) to yield compound $\mathbf{1 7}$ as white solid.

Yield: $410 \mathrm{mg}(71 \%)$. $\mathrm{R}_{f}$ : 0.48 (Pet. ether /EtOAc 9:1, visualized with 1.3\% ninhydrine solution). ${ }^{1} \mathrm{H} \mathrm{NMR}\left(\mathrm{CDCl}_{3}, 500 \mathrm{MHz}, \mathrm{ppm}\right) \delta 5.28(\mathrm{~d}, J=6.0 \mathrm{~Hz}, 1 \mathrm{H}), 4.30(\mathrm{p}, \mathrm{J}=7.0 \mathrm{~Hz}$, $1 \mathrm{H}), 2.55-2.40(\mathrm{~m}, 2 \mathrm{H}), 1.62-1.54(\mathrm{~m}, 2 \mathrm{H}), 1.43(\mathrm{~s}, 9 \mathrm{H}), 1.31(\mathrm{~d}, J=7.2 \mathrm{~Hz}, 3 \mathrm{H}), 1.29-$ $1.21(\mathrm{~m}, 24 \mathrm{H}), 0.87(\mathrm{t}, J=7.0 \mathrm{~Hz}, 3 \mathrm{H}) .{ }^{13} \mathrm{C} \mathrm{NMR}\left(\mathrm{CDCl}_{3}, 126 \mathrm{MHz}, \mathrm{ppm}\right) \delta 209.79,155.18$, 79.65, 55.02, 39.21, 31.93, 29.70, 29.67, 29.60, 29.45, 29.37, 29.22, 28.35, 23.59, 22.69, 17.97, 14.13. ESI-MS $m / z$ calcd for $\mathrm{C}_{23} \mathrm{H}_{46} \mathrm{NO}_{3}[\mathrm{M}+\mathrm{H}]^{+} 384.34$; observed: 384.3 . 


\section{Synthesis of (2S,3R)-tert-butyl (-3-hydroxyoctadecan-2-yl)carbamate 18}

To a stirred solution of compound $17(0.34 \mathrm{~g}, 0.89 \mathrm{mmol})$ in dry ethanol $(2 \mathrm{~mL})$ under argon atmosphere at $-78^{\circ} \mathrm{C}$ was added portionwise lithium tri-(tert-butoxy)-aluminum hydride $(0.57$ $\mathrm{g}, 2.2 \mathrm{mmol}$ ) over a period of $20 \mathrm{~min}$. After the resulting reaction mixture was allowed to stir at the same conditions for $2 \mathrm{~h}$ (as judged by TLC analysis: Pet. ether / EtOAc 4:1; $\mathrm{R}_{f}$ (adduct)= $0.69 ; \mathrm{R}_{f}$ (product) $=0.57$; visualized with $1.3 \%$ ninhydrine solution), an ice-cold $1 \mathrm{M} \mathrm{HCl}$ solution $(100 \mathrm{~mL})$ was added dropwise to quench the reaction. The resulting mixture was allowed to warm gradually to ambient temperature and subsequently diluted with ethylacetate $(100 \mathrm{~mL})$. The layers were separated and the aqueous layer was extracted again with ethylacetate $(2 \times 100$ $\mathrm{mL}$ ). The combined organic extracts was washed with sat. $\mathrm{NaHCO}_{3}$ solution and brine, dried over anhydrous $\mathrm{Na}_{2} \mathrm{SO}_{4}$, filtered, and concentrated under reduced pressure. Flash column chromatography for the obtained residue over silica gel using petroleum ether and ethylacetate as eluents (15-23\% ethylacetate in petroleum ether) afforded the desired product $\mathbf{1 8}$ as a white solid.

Yield: $285 \mathrm{mg}(83 \%)$. R $\mathrm{R}_{f} 0.57$ (Pet. ether /EtOAc 4:1, visualized with 1.3\% ninhydrine solution). ${ }^{1} \mathrm{H} \mathrm{NMR}\left(\mathrm{CDCl}_{3}, 500 \mathrm{MHz}, \mathrm{ppm}\right) \delta 4.63$ (br. s, 1H), 3.77-3.53 (m, $\left.2 \mathrm{H}\right), 1.46(\mathrm{~s}, 9 \mathrm{H})$, 1.45-1.22 (m, 28H), 1.07 (d, $J=6.8 \mathrm{~Hz}, 3 \mathrm{H}), 0.88(\mathrm{t}, J=6.4 \mathrm{~Hz}, 3 \mathrm{H}) .{ }^{13} \mathrm{C} \mathrm{NMR}\left(\mathrm{CDCl}_{3}, 126\right.$ $\mathrm{MHz}, \mathrm{ppm}) \delta 155.78,79.56,74.57,50.68,33.62,32.13,29.79,29.73,29.58,29.36,28.46$, 26.23, 22.68, 14.43, 14.11. ESI-MS $m / z$ calcd for $\mathrm{C}_{23} \mathrm{H}_{48} \mathrm{NO}_{3}[\mathrm{M}+\mathrm{H}]^{+} 386.36$; observed: 386.4 .

\section{Synthesis of $(2 S, 3 R)$-2-aminooctadecan-3-ol 19}

A solution of compound $18(0.15 \mathrm{~g}, 0.38 \mathrm{mmol})$ in dry methanol $(4 \mathrm{~mL})$ at $0^{\circ} \mathrm{C}$ was treated with acetyl chloride $(272 \mu \mathrm{L}, 3.8 \mathrm{mmol})$ in dropwise over a period of $10 \mathrm{~min}$. After the resulting reaction mixture was stirred at the same conditions for $30 \mathrm{~min}$ and for additional $1 \mathrm{~h}$ at ambient temperature (as controlled by TLC analysis; Pet. ether / EtOAc 3:2; $\mathrm{R}_{f}$ (adduct) $=0.51 ; \mathrm{R}_{f}$ (product $)=0.0$; visualized with $1.3 \%$ ninhydrine solution), the solvent was removed under reduced pressure. The obtained residue was portioned between diethylether $(100 \mathrm{~mL})$ and sat. $\mathrm{NaHCO}_{3}$ solution $(90 \mathrm{~mL})$. The layers were separated and the aqueous layer was extracted again with diethylether $(2 \times 80 \mathrm{~mL})$. The combined organic layers was washed with brine, dried over anhydrous $\mathrm{Na}_{2} \mathrm{SO}_{4}$, filtered, and concentrated in vacuo to afford a white waxy solid. The crude product was further purified by flash column chromatography over silica gel using ethylacetate and isopropanol as eluents (0-10\% isopropanol in ethylacetate) to provide the final product 19 as a white solid.

Yield: $84 \mathrm{mg}$ (77\%). $\mathrm{R}_{f}$ : 0.47 (EtOAc/ iso-propanol 9:1, visualized with $1.3 \%$ ninhydrine). ${ }^{1} \mathrm{H}$ NMR (MeOD, $500 \mathrm{MHz}, \mathrm{ppm}) \delta 3.72-3.68(\mathrm{~m}, 1 \mathrm{H}), 3.27$ (qd, $J=6.8,3.0 \mathrm{~Hz}, 1 \mathrm{H}), 1.53$ (dt, $J=11.0,8.2 \mathrm{~Hz}, 1 \mathrm{H}), 1.45(\mathrm{dt}, J=13.6,4.6 \mathrm{~Hz}, 2 \mathrm{H}), 1.38-1.27(\mathrm{~m}, 26 \mathrm{H}), 1.22(\mathrm{~d}, J=6.8 \mathrm{~Hz}$, $3 \mathrm{H}), 0.90(\mathrm{t}, J=7.0 \mathrm{~Hz}, 3 \mathrm{H}) .{ }^{13} \mathrm{C} \mathrm{NMR}(\mathrm{MeOD}, 126 \mathrm{MHz}, \mathrm{ppm}) \delta 71.65,52.62,34.00,33.07$, 30.78, 30.76, 30.72, 30.67, 30.63, 30.47, 26.97, 23.73, 14.43, 12.05. ESI-MS: $m / z$ calcd for $\mathrm{C}_{18} \mathrm{H}_{40} \mathrm{NO}[\mathrm{M}+\mathrm{H}]^{+}$286.32; observed 286.3.

Synthesis of (tert-butoxycarbonyl)glycine (20) 
A stirred solution of glycine $(1.1 \mathrm{~g}, 14.8 \mathrm{mmol})$ in aqueous $1 \mathrm{M} \mathrm{NaOH}$ solution $(50 \mathrm{~mL})$ at $0^{\circ} \mathrm{C}$ was treated in dropwise with a solution of di-tert-butyl dicarbonate $(3.4 \mathrm{~g}, 16.3 \mathrm{mmol}$, in dioxane) over a period of $20 \mathrm{~min}$. After the resulting reaction mixture was stirred at the same conditions for $1 \mathrm{~h}$ and for additional $12 \mathrm{~h}$ at ambient temperature, the solvent was removed under reduced pressure. The mixture was washed with $\mathrm{n}$-hexane $(50 \mathrm{~mL})$ to remove the unreacted $\mathrm{Boc}_{2} \mathrm{O}$. The aqueous residue was cooled again to $0^{\circ} \mathrm{C}$ and was carefully acidified by $1 \mathrm{M} \mathrm{KHSO}_{4}$ solution. The obtained mixture was diluted with ethylacetate $(100 \mathrm{~mL})$ and the layers were separated. The aqueous layer was extracted with ethylacetate $(2 \times 100 \mathrm{~mL})$, and the combined organic extracts were dried over anhydrous $\mathrm{Na}_{2} \mathrm{SO}_{4}$, filtered, and concentrated. The obtained crude product $\mathbf{2 0}$ was pure as determined by NMR- analysis and was used directly in the next step without any further purification.

Yield: $2.3 \mathrm{mg}$ (89\%). ${ }^{1} \mathrm{H}$ NMR $\left(\mathrm{CDCl}_{3}, 500 \mathrm{MHz}, \mathrm{ppm}\right): \delta 6.78$ (br.s, $\left.1 \mathrm{H}\right), 3.97$ (br.s, $\left.2 \mathrm{H}\right), 1.45$ (s, 9H). ${ }^{13} \mathrm{C} \mathrm{NMR}\left(\mathrm{CDCl}_{3}, 126 \mathrm{MHz}, \mathrm{ppm}\right): \delta 178.23,155.16,80.57 ; 43.66,28.36$. ESI-LCMS: $\mathrm{m} / \mathrm{z}$ calcd for $\mathrm{C}_{7} \mathrm{H}_{13} \mathrm{NO}_{4}[\mathrm{M}+\mathrm{H}]^{+}$176.09; observed 176.1.

\section{Synthesis of tert-butyl (2-(methoxy(methyl)amino)-2-oxoethyl)carbamate (21)}

To a stirred solution of $N$-Boc-glycine $20(1.2 \mathrm{~g}, 6.75 \mathrm{mmol})$ in dry dichloromethane $(25 \mathrm{~mL})$ under argon atmosphere at $-10^{\circ} \mathrm{C}$ was added $N$-methylmorpholine $(2.3 \mathrm{~mL}, 20.3 \mathrm{mmol})$, followed by $\mathrm{N}, \mathrm{O}$-dimethylhydroxylamine hydrochloride $(0.79 \mathrm{~g}, 8.1 \mathrm{mmol})$. The resulting mixture was treated at the same conditions with 1-ethyl-3-(3dimethylaminopropyl)carbodiimide hydrochloride $(1.55 \mathrm{~g}, 8.1 \mathrm{mmol})$ in portionwise over a period of $30 \mathrm{~min}$. After being stirred at the same conditions for $2 \mathrm{~h}$ (as detected by TLC analysis; EtOAc $100 \% ; \mathrm{R}_{f(\text { adduct })}=0.1 ; \mathrm{R}_{f(\text { product })}=0.54$; visualized with $1.3 \%$ ninhydrine solution), the reaction was quenched with sat. $\mathrm{NH}_{4} \mathrm{Cl}(100 \mathrm{~mL})$. The mixture was diluted with $\mathrm{DCM}$ and the layers were separated. The aqueous layer was extracted again with DCM $(2 \times 80 \mathrm{~mL})$, and the combined organic layers were washed with sat. $\mathrm{NaHCO}_{3}$ solution and brine, dried over anhydrous $\mathrm{Na}_{2} \mathrm{SO}_{4}$, filtered, and concentrated to afford a white solid of the desired product 21 . The obtained product was pure as determined by LCMS- and NMR-analysis and was directly used in the next step without any further purification.

Yield: $1.15 \mathrm{mg}$ (78\%). $\mathrm{R}_{f}$ : 0.54 (EtOAc $100 \%$, visualized with $1.3 \%$ ninhydrine solution). ${ }^{1} \mathrm{H}$ NMR $\left(\mathrm{CDCl}_{3}, 500 \mathrm{MHz}, \mathrm{ppm}\right): \delta 5.28$ (br.s, 1H), 4.09 (br.s, 2H), 3.71 (s, 3H), 3.22 (s, 3H), 1.46 (s, 9H). ${ }^{13} \mathrm{C} \mathrm{NMR}\left(\mathrm{CDCl}_{3}, 126 \mathrm{MHz}, \mathrm{ppm}\right): \delta 173.78,155.23,79.63,61.39,41.74,32.42$, 28.36. ESI-LCMS: $m / z$ calcd for $\mathrm{C}_{9} \mathrm{H}_{19} \mathrm{~N}_{2} \mathrm{O}_{4}[\mathrm{M}+\mathrm{H}]^{+}$219.13; observed 219.1.

\section{Synthesis of tert-butyl (2-oxoheptadecyl)carbamate (22)}

1-pentadecylmagnesium bromide was synthesized as follows; A mixture of magnesium powder $(0.51 \mathrm{~g}, 21 \mathrm{mmol})$ in dry THF $(2 \mathrm{~mL})$ under argon atmosphere was treated with a catalytic drop of 1,2-dibromoethane followed by a dropwise addition of a solution of 1bromopentadecane $(1.5 \mathrm{~g}, 5.2 \mathrm{mmol}, 1 \mathrm{M}$ in dry TFH). The resulting reaction mixture was stirred under reflux for $2 \mathrm{~h}$ to afford a transparent solution of 1-pentadecylmagnesium bromide which was used in the next step.

To a stirred solution of compound 21 (330 mg, $1.5 \mathrm{mmol})$ in dry THF (15 mL) under argon atmosphere at $0 \mathrm{C}$ was added dropwise a freshly prepared 1-pentadecylmagnesium bromide 
solution over a period of $20 \mathrm{~min}$. After being stirred for $2 \mathrm{~h}$ at ambient temperature (as monitored by TLC analysis; Pet. ether/ EtOAc 4:1; $\mathrm{R}_{f}$ (adduct) $=0.19 ; \mathrm{R}_{f}$ (product) $=0.68$; visualized with $1.3 \%$ ninhydrine), the reaction mixture was added in dropwise to an ice-cooled $1 \mathrm{M} \mathrm{HCl}$ solution (100 $\mathrm{mL})$ to quench. The resulting mixture was diluted with ethylacetate $(100 \mathrm{~mL})$ and the layers were separated. The aqueous layer was extracted with ethylacetate $(2 \times 100 \mathrm{~mL})$, and the combined organic layers were washed with sat. $\mathrm{NaHCO}_{3}$ solution and brine, dried over $\mathrm{Na}_{2} \mathrm{SO}_{4}$, filtered, and concentrated. The obtained residue was purified by flash column chromatography over silica gel using petroleum ether and ethylacetate as eluents (0-14\% ethylacetate in petroleum ether) to afford compound $\mathbf{2 2}$ as a white solid.

Yield: $340 \mathrm{mg}(62 \%) . \mathrm{R}_{f}$ : 0.47 (cyclohexane/EtOAc 9:1, visualized with $1.3 \%$ ninhydrine solution). ${ }^{1} \mathrm{H} \mathrm{NMR}\left(\mathrm{CDCl}_{3}, 500 \mathrm{MHz}, \mathrm{ppm}\right) \delta 4.11$ (br.s, $\left.2 \mathrm{H}\right), 2.58-2.42$ (m, 2H), $1.66-1.58$ $(\mathrm{m}, 2 \mathrm{H}), 1.44(\mathrm{~s}, 9 \mathrm{H}), 1.28-1.20(\mathrm{~m}, 24 \mathrm{H}), 0.87(\mathrm{t}, J=6.9 \mathrm{~Hz}, 3 \mathrm{H}) \cdot{ }^{13} \mathrm{C} \mathrm{NMR}\left(\mathrm{CDCl}_{3}, 126\right.$ MHz, ppm): $\delta$ 209.52, 155.26, 79.68, 42.57, 40.12, 33.25, 29.79, 29.61, 29.59, 29.47, 29.41, 29.26, 28.56, 23.63, 22.72, 14.16. ESI-LCMS: $m / z$ calcd for $\mathrm{C}_{22} \mathrm{H}_{43} \mathrm{NO}_{3} \mathrm{Na}[\mathrm{M}+\mathrm{Na}]^{+} 392.31$; observed 392.3 .

\section{Synthesis of (R)-tert-butyl-(2-hydroxyheptadecyl)carbamate (23)}

Lithium tri-(tert-butoxy)-aluminum hydride $(0.49 \mathrm{~g}, 1.9 \mathrm{mmol})$ was added in portionwise to a stirred solution of compound $22(285 \mathrm{mg}, 0.76 \mathrm{mmol})$ in dry ethanol $(2 \mathrm{~mL})$ under argon atmosphere at $-78 \mathrm{C}$. After the resulting reaction mixture was stirred at the same conditions for $3 \mathrm{~h}$ (as detected by TLC analysis; Pet. ether/ EtOAc 4:1; $\mathrm{R}_{f}$ (adduct) $=0.69 ; \quad \mathrm{R}_{f}$ (product) $=0.55$; visualized with $1.3 \%$ ninhydrine), an ice-cooled $1 \mathrm{M} \mathrm{HCl}$ solution $(100 \mathrm{~mL})$ was added in dropwise over a period of $20 \mathrm{~min}$. The resulting mixture was allowed to warm to ambient temperature and was extracted with ethylacetate $(3 \times 100 \mathrm{~mL})$. The combined organic extracts were washed with sat. $\mathrm{NaHCO}_{3}$ solution and brine, dried over $\mathrm{Na}_{2} \mathrm{SO}_{4}$, filtered, and concentrated under reduced pressure. Purification of the resultant residue by flash column chromatography over silica gel using petroleum ether and ethylacetate as eluents (10-20\% ethylacetate in petroleum ether) afforded the desired product $\mathbf{2 3}$ as a white waxy-solid.

Yield: $210 \mathrm{mg}(74 \%)$. $\mathrm{R}_{f}$ : 0.55 (cyclohexane/EtOAc 4:1, visualized with $1.3 \%$ ninhydrine solution). ${ }^{1} \mathrm{H} \mathrm{NMR}\left(\mathrm{CDCl}_{3}, 500 \mathrm{MHz}, \mathrm{ppm}\right): \delta{ }^{1} \mathrm{H} \mathrm{NMR}\left(\mathrm{CDCl}_{3}, 500 \mathrm{MHz}, \mathrm{ppm}\right) \delta 4.48$ (br. s, $1 \mathrm{H}), 3.79-3.72(\mathrm{~m}, 1 \mathrm{H}), 3.17-2.89(\mathrm{~m}, 2 \mathrm{H}), 1.47(\mathrm{~s}, 9 \mathrm{H}), 1.47-1.24(\mathrm{~m}, 28 \mathrm{H}), 0.89(\mathrm{t}, J=6.5$ $\mathrm{Hz}, 3 \mathrm{H}) .{ }^{13} \mathrm{C} \mathrm{NMR}\left(\mathrm{CDCl}_{3}, 126 \mathrm{MHz}, \mathrm{ppm}\right): \delta$ 155.62, 79.55, 62.27, 43.71, 34.52, 32.63, 29.78, 29.75, 29.57, 29.39, 28.47, 26.28, 22.67, 14.11. ESI-LCMS: $m / z$ calcd for $\mathrm{C}_{22} \mathrm{H}_{46} \mathrm{NO}_{3}[\mathrm{M}+\mathrm{H}]^{+}$ 372.35; observed 372.3 .

\section{Synthesis of $(R)$-1-aminoheptadecan-2-ol (24)}

Acetyl chloride ( $305 \mu \mathrm{L}, 4.3 \mathrm{mmol}$ ) was added in dropwise to a stirred solution of compound $23(0.16 \mathrm{~g}, 0.43 \mathrm{mmol})$ in dry methanol $(4 \mathrm{~mL})$ at $0^{\circ} \mathrm{C}$. The resulting reaction mixture was allowed to stir at the same conditions for $30 \mathrm{~min}$ and for additional $2 \mathrm{~h}$ at ambient temperature (as monitored by TLC analysis), during while a white solid was formed. The mixture was filtrated and the residue was washed several times with ice-cooled diethylether to afford a white waxy-solid crude product. Purification of the crude product by flash column chromatography over silica gel using isopropanol and ethylacetate as eluents (0-10\% isopropanol in ethyacetate) provided the final product $\mathbf{2 4}$ as a white solid. 
Yield: $76 \mathrm{mg}(65 \%) . \mathrm{R}_{f}$ : 0.39 (EtOAc/iso-propanol 10:1, visualized with $1.3 \%$ ninhydrine). ${ }^{1} \mathrm{H}$ NMR (MeOD, $500 \mathrm{MHz}$, ppm) $\delta 3.77-3.70(\mathrm{~m}, 1 \mathrm{H}), 3.01(\mathrm{dd}, J=12.7,3.0 \mathrm{~Hz}, 1 \mathrm{H}), 2.75$ (dd, $J=12.7,9.5 \mathrm{~Hz}, 1 \mathrm{H}), 1.48(\mathrm{t}, J=7.8 \mathrm{~Hz}, 2 \mathrm{H}), 1.43-1.23(\mathrm{~m}, 26 \mathrm{H}), 0.90(\mathrm{t}, J=6.9 \mathrm{~Hz}, 3 \mathrm{H})$. ${ }^{13} \mathrm{C}$ NMR (MeOD, $\left.126 \mathrm{MHz}, \mathrm{ppm}\right) \delta$ 68.76, 46.09, 36.03, 33.07, 30.78, 30.72, 30.67, 30.64, 30.46, 26.40, 23.73. ESI-MS m/z clcd for $\mathrm{C}_{17} \mathrm{H}_{38} \mathrm{NO}[\mathrm{M}+\mathrm{H}]^{+}$: 272.29; observed 272.3.

\section{Synthesis of (S)-tert-butyl-3-oxopent-4-en-2-ylcarbamate (25)}

A stirred solution of compound $9(3 \mathrm{~g}, 13 \mathrm{mmol})$ in dry THF $(65 \mathrm{~mL})$ under an argon atmosphere at $-20^{\circ} \mathrm{C}$ was added dropwise a solution of vinylmagnesium bromide $(45.5 \mathrm{~mL}$, $45.5 \mathrm{mmol}, 1 \mathrm{M}$ solution in THF); the addition rate was adjusted so as to keep the internal temperature at $-20{ }^{\circ} \mathrm{C}$ and it took $45 \mathrm{~min}$ to complete. The resulting reaction mixture was allowed to stir at the same conditions for $30 \mathrm{~min}$ and for additional $3 \mathrm{~h}$ at ambient temperature (as judged by TLC analysis; Pet. ether/ EtOAc 4:1; $\mathrm{R}_{f \text { (adduct) }}=0.2 ; \mathrm{R}_{f}$ (product) $=0.54$; visualized with $1.3 \%$ ninhydrine). The reaction mixture was added dropwisely to an ice-coold $1 \mathrm{M} \mathrm{HCl}$ solution to quench; again so as to keep the temperature of solution below $-10^{\circ} \mathrm{C}$. The resultant mixture was diluted with ethylacetate and the layers were separated. The aqueous layer was extracted with ethylacetate $(2 \times 100 \mathrm{~mL})$, and the combined organic extracts were subsequently washed with saturated $\mathrm{NaHCO}_{3}$ solution and brine, dried over anhydrous $\mathrm{Na}_{2} \mathrm{SO}_{4}$, filtered and concentrated in vacuo. The resultant residue was purified by flash column chromatography over silica gel using cyclohexane and ethylacetate as eluents (from 5-15\% ethylacetate in cyclohexane) to afford the desired product $\mathbf{2 5}$ as a white solid.

Yield: $1.7 \mathrm{~g}(66 \%) . \mathrm{R}_{f}$. 0.54 (cyclohexane/ethylacetate 4:1, visualized with $1.3 \%$ ninhydrine solution). ${ }^{1} \mathrm{H} \mathrm{NMR}\left(\mathrm{CDCl}_{3}, 500 \mathrm{MHz}, \mathrm{ppm}\right): \delta 6.48(\mathrm{dd}, J=17.4,9.9 \mathrm{~Hz}, 1 \mathrm{H}) .6 .37(\mathrm{dd}, J=$ 17.4, $1.9 \mathrm{~Hz}, 1 \mathrm{H}), 5.88$ (dd, $J=10.2,1.9 \mathrm{~Hz}, 1 \mathrm{H}), 5.37$ (br s, 1H), 4.54-4.67 (m, 1H), 1.44 (s, $9 \mathrm{H}), 1.33(\mathrm{~d}, J=6.9 \mathrm{~Hz}, 3 \mathrm{H}) .{ }^{13} \mathrm{C} \mathrm{NMR}\left(\mathrm{CDCl}_{3}, 126 \mathrm{MHz}, \mathrm{ppm}\right): \delta 198.68,155.23,132.91$, 130.34, 79.51, 53.20, 28.63, 18.42. ESI-LCMS $m / z$ calcd for $\mathrm{C}_{10} \mathrm{H}_{18} \mathrm{NO}_{3}[\mathrm{M}+\mathrm{H}]^{+} 200.13$; observed 200.1.

\section{Synthesis of (2S,3R)-tert-butyl-(3-hydroxypent-4-en-2-yl)carbamate 26}

To a stirred solution of compound $25(1.5 \mathrm{~g}, 7.5 \mathrm{mmol})$ in anhydrous ethanol $(15 \mathrm{~mL})$ under an argon atmosphere at $-78^{\circ} \mathrm{C}$ was added in portionwise lithium tri-(tert-butoxy)-aluminum hydride $(4.8 \mathrm{~g}, 18.75 \mathrm{mmol})$; the addition rate was adjusted so as to keep the internal temperature below $-65^{\circ} \mathrm{C}$ and it took $30 \mathrm{~min}$ to complete. After the resulting reaction mixture was allowed to stir at the same conditions for $3 \mathrm{~h}$ (as judged by TLC analysis; Pet. ether/ EtOAc $4: 1 ; \mathrm{R}_{f \text { (adduct) }}=0.54 ; \mathrm{R}_{f}$ (product) $=0.42$; visualized with $1.3 \%$ ninhydrine), an ice-coold $1 \mathrm{M} \mathrm{HCl}$ solution $(100 \mathrm{~mL})$ was added dropwise to quench the reaction; again so as to keep the internal temperature below $-65^{\circ} \mathrm{C}$ and it took 30 min to complete. The resulting mixture was diluted with ethylacetate and was allowed to gradually warm to ambient temperature. The layers were separated and the aqueous layer was subsequently extracted with ethylacetate $(2 \mathrm{x} 100 \mathrm{~mL})$. The combined organic layers were sequentially washed with saturated $\mathrm{NaHCO}_{3}$ solution and brine, dried over anhydrous $\mathrm{Na}_{2} \mathrm{SO}_{4}$, filtered and concentrated under reduced pressure. Flash column 
chromatography of the resultant crude mixture over silica gel using cyclohexane and ethylacetate as eluents (from 15-25\% ethylacetate in cyclohexane) afforded the desired product 26 as a white solid.

Yield: $1.1 \mathrm{~g}(73 \%)$. $\mathrm{R}_{f} \cdot 0.42$ (cyclohexane/ethylacetate 4:1, visualized with $\mathrm{KMnO}_{4}$ solution). ${ }^{1} \mathrm{H} \mathrm{NMR}\left(\mathrm{CDCl}_{3}, 500 \mathrm{MHz}, \mathrm{ppm}\right): \delta 5.85(\mathrm{ddd}, J=17.2,10.6,5.5 \mathrm{~Hz}, 1 \mathrm{H}), 5.33(\mathrm{dd}, J=17.2$, $1.6 \mathrm{~Hz}, 1 \mathrm{H}), 5.24$ (dd, $J=10.5,1.5 \mathrm{~Hz}, 1 \mathrm{H}), 4.76-4.62(\mathrm{~m}, 1 \mathrm{H}), 4.23-4.16$ (m, 1H), 2.85 (br. s, $1 \mathrm{H}), 1.45$ (s, 9H), 1.09 (d, $J=6.9 \mathrm{~Hz}, 3 \mathrm{H}) .{ }^{13} \mathrm{C} \mathrm{NMR}\left(\mathrm{CDCl}_{3}, 126 \mathrm{MHz}, \mathrm{ppm}\right): \delta 156.46,136.98$, 116.68, 79.89, 75.92, 50.96, 28.50, 15.46. ESI-LCMS: $m / z$ calcd for $\mathrm{C}_{10} \mathrm{H}_{19} \mathrm{NO}_{3} \mathrm{Na}[\mathrm{M}+\mathrm{Na}]^{+}$ 224.13; observed 224.1.

\section{Synthesis of 10-bromo-1-decene}

A stirred solution of 1,10-dibromodecane (7 g, $23.3 \mathrm{mmol})$ in anhydrous THF (200 mL) under an argon atmosphere was treated in portionwise with tert-BuOK $(2.9 \mathrm{~g}, 25.6 \mathrm{mmol})$ over a period of $30 \mathrm{~min}$. After being stirred at $50^{\circ} \mathrm{C}$ for $12 \mathrm{~h}$ (as detected by TLC analysis; Pet. ether; $\mathrm{R}_{f \text { (adduct) }}=0.58 ; \mathrm{R}_{f \text { (product) }}=0.89$; visualized with $\mathrm{KMnO}_{4}$ solution), the reaction mixture was cooled to $0^{\circ} \mathrm{C}$ and subsequently quenched with water. The resulting mixture was diluted with diethylether, and the layers were separated. The aqueous layer was extracted with diethylether $(2 \times 100 \mathrm{~mL})$, and the combined organic layers were washed with brine, dried over anhydrous $\mathrm{Na}_{2} \mathrm{SO}_{4}$, filtered and concentrated under reduced pressure. Purification of the obtained crude product by flash column chromatography over silica gel using petroleum ether as eluent provided the desired product 10-bromo-1-decene as colorless oil.

Yield: $3.1 \mathrm{~g}(61 \%) . \mathrm{R}_{f}$ : 0.84 (n-hexane $100 \%$, visualized with $\mathrm{KMnO}_{4}$ solution). ${ }^{1} \mathrm{H} \mathrm{NMR}$ $\left(\mathrm{CDCl}_{3}, 500 \mathrm{MHz}, \mathrm{ppm}\right): \delta 5.81(\mathrm{ddt}, J=16.9,10.1,6.7 \mathrm{~Hz}, 1 \mathrm{H}), 5.04-4.91(\mathrm{~m}, 2 \mathrm{H}), 3.41(\mathrm{t}$, $J=6.9 \mathrm{~Hz}, 2 \mathrm{H}), 2.03(\mathrm{dt}, J=7.6,4.0 \mathrm{~Hz}, 2 \mathrm{H}), 1.92-1.78(\mathrm{~m}, 2 \mathrm{H}), 1.49-1.28(\mathrm{~m}, 10 \mathrm{H}) .{ }^{13} \mathrm{C}$ $\mathrm{NMR}\left(\mathrm{CDCl}_{3}, 126 \mathrm{MHz}, \mathrm{ppm}\right): \delta$ 139.29, 114.34, 34.20, 33.91, 32.97, 29.42, 29.14, 29.01, $28.86,28.30$.

\section{Synthesis of $(2 S, 3 R, 4 E)$-tert-butyl-(13-bromo-3-hydroxytridec-4-en-2-yl)carbamate (27)}

A stirred mixture of aminoalcohol derivative 26 (660 mg, $3.25 \mathrm{mmol}$ ) and 10-bromo-1-decene $(2.9 \mathrm{~g}, 13 \mathrm{mmol})$ in anhydrous d-chloroform $(10 \mathrm{~mL})$ under an argon atmosphere was treated with a catalytic amount of $p$-benzoquinone $(10 \mathrm{~mol} \%)$ followed by Grubbs Catalyst $2^{\text {nd }}$ Generation (10 mol\%, in one portion). After the resulting reaction mixture was stirred under reflux for $12 \mathrm{~h}$ (as detected by TLC analysis, until no further change in the composition of the reaction mixture, Pet. ether/ EtOAc $4: 1 ; \mathrm{R}_{f \text { (adduct) }}=0.42 ; \mathrm{R}_{f \text { (product) }}=0.51$; visualized with $1.3 \%$ ninhydrine solution), the solvent was removed under reduced pressure. Flash column chromatography for the obtained residue over silica gel using cyclohexane and ethylacetate as eluents (from 10-25\% ethylacetate in cyclohexane) provided the desired product 27 as a colorless oil.

Yield: $725 \mathrm{mg}$ (57\%). $R_{\mathrm{f}}$ : 0.51 (Pet. ether /ethylacetate 4:1, visualized with $1.3 \%$ ninhydrine solution). ${ }^{1} \mathrm{H} \mathrm{NMR}\left(\mathrm{CDCl}_{3}, 500 \mathrm{MHz}, \mathrm{ppm}\right): \delta 5.70$ (dtd, $\left.J=15.0,6.8,1.1 \mathrm{~Hz}, 1 \mathrm{H}\right), 5.43$ (dd, $J$ $=15.4,6.6 \mathrm{~Hz}, 1 \mathrm{H}), 4.10(\mathrm{~d}, J=2.4 \mathrm{~Hz}, 1 \mathrm{H}), 3.83-3.73(\mathrm{~m}, 1 \mathrm{H}), 3.40(\mathrm{t}, J=6.9 \mathrm{~Hz}, 2 \mathrm{H}), 2.04$ 
$(\mathrm{q}, J=7.0 \mathrm{~Hz}, 2 \mathrm{H}), 1.88-1.81(\mathrm{~m}, 2 \mathrm{H}), 1.44(\mathrm{~s}, 9 \mathrm{H}), 1.42-1.27(\mathrm{~m}, 10 \mathrm{H}), 1.07(\mathrm{~d}, J=6.9$ $\mathrm{Hz}, 3 \mathrm{H}) .{ }^{13} \mathrm{C} \mathrm{NMR}\left(\mathrm{CDCl}_{3}, 126 \mathrm{MHz}, \mathrm{ppm}\right): \delta$ 156.40, 134.05, 128.57, 79.78, 75.89, 51.21, 34.16, 32.94, 32.46, 29.38, 29.25, 29.16, 28.83, 28.53, 28.28, 15.66. ESI-MS: $m / z$ calcd for $\mathrm{C}_{18} \mathrm{H}_{35} \mathrm{NO}_{3} \mathrm{Br}[\mathrm{M}+\mathrm{H}]^{+}$392.18; observed 392.2.

\section{Synthesis of (2S,3R)-tert-butyl (13-bromo-3-hydroxytridecan-2-yl-4,5- $\left.d_{2}\right)$ carbamate (28)}

To a stirred solution of compound $27(660 \mathrm{mg}, 1.7 \mathrm{mmol})$ in dry d-methanol $(20 \mathrm{~mL})$ under argon atmosphere at ambient temperature was added a catalytic amount of $10 \% \mathrm{Pd} / \mathrm{C}(10 \mathrm{mg})$ followed by catalytic drop of d-acetic acid. The reaction vessel was evacuated and backfilled with deuterium gas (this process was repeated 2 times) and the resulting heterogeneous reaction mixture was allowed to stir at the same conditions for 14h (as detected by HPLC analysis for complete reduction reaction). The reaction mixture was filtered through a short pad of Celite, which was rinsed several times with methanol $(3 \times 50 \mathrm{~mL})$. The combined filtrates was concentrated under reduced pressure and the obtained residue was purified by flash column chromatography over silica gel using cylcohexane and ethylacetate as eluents (10-20\% ethylacetate in cyclohexane) to provide compound $\mathbf{2 8}$ as a colorless oil.

Yield: $540 \mathrm{mg}(81 \%)$. Rf. 0.5 (Pet. ether/ EtOAc 4:1, visualized with $1.3 \%$ ninhydrine solution). ${ }^{1} \mathrm{H} \mathrm{NMR}\left(\mathrm{CDCl}_{3}, 500 \mathrm{MHz}, \mathrm{ppm}\right): \delta 4.76(\mathrm{~s}, 1 \mathrm{H}), 3.67(\mathrm{~d}, J=15.5 \mathrm{~Hz}, 1 \mathrm{H}), 3.63(\mathrm{t}, J=6.3 \mathrm{~Hz}$, $1 \mathrm{H}), 3.40(\mathrm{t}, J=6.9 \mathrm{~Hz}, 2 \mathrm{H}), 1.88-1.81(\mathrm{~m}, 2 \mathrm{H}), 1.44(\mathrm{~s}, 9 \mathrm{H}), 1.41-1.22(\mathrm{~m}, 14 \mathrm{H}), 1.07(\mathrm{~d}$, $J=6.8 \mathrm{~Hz}, 3 \mathrm{H}) .{ }^{13} \mathrm{C} \mathrm{NMR}\left(\mathrm{CDCl}_{3}, 126 \mathrm{MHz}, \mathrm{ppm}\right): \delta 156.02,79.60,74.60,50.73,34.19,33.58$, 32.97, 29.77, 29.63, 29.57, 29.53, 28.88, 28.55, 28.30, 26.17, 14.50. ESI-LCMS: $\mathrm{m} / \mathrm{z}$ calcd for $\mathrm{C}_{18} \mathrm{H}_{35} \mathrm{D}_{2} \mathrm{NO}_{3} \mathrm{Br}[\mathrm{M}+\mathrm{H}]^{+}$396.21; observed 396.2.

\section{Synthesis of $(4 S, 5 R)$-tert-butyl-5-(10-bromodecyl-1,2-d2)-2,2,4-trimethyloxazolidine-3- carboxylate (29)}

To a stirred solution of compound $28(515 \mathrm{mg}, 1.3 \mathrm{mmol})$ in anhydrous toluene (13 $\mathrm{mL})$ under an argon atmosphere was added 2,2-dimethoxypropane $(0.8 \mathrm{~mL}, 6.5 \mathrm{mmol})$, followed by a catalytic amount of $p$-toluensulfonic acid monohydrate (10 mol\%). After being stirred under reflux in a Dean-Stark apparatus for $2 \mathrm{~h}$ (as judged by the TLC analysis; Pet. ether/ EtOAc 4:1; $\mathrm{R}_{f \text { (adduct) }}=0.5 ; \mathrm{R}_{f \text { (product) }}=0.78$; visualized with $1.3 \%$ ninhydrine solution), the reaction mixture was cooled to ambient temperature, diluted with ethylacetate, and successfully quenched with sat. $\mathrm{NaHCO}_{3}$ solution $(80 \mathrm{~mL})$. The mixture was transferred to separating funnel and the layers were separated. The aqueous layer was extracted again with ethylacetate $(2 \times 80 \mathrm{~mL})$ and the combined organic layers were washed with brine, dried over anhydrous $\mathrm{Na}_{2} \mathrm{SO}_{4}$, filtered and concentrated. Flash column chromatography of the resultant crude residue over silica gel using cyclohexane and ethylacetate as eluents ( $0 \%$ to $10 \%$ ethylacetate in cyclohexane) provided the desired product $\mathbf{2 9}$ as a colorless oil.

Yield: $505 \mathrm{mg}$ (89\%). $\mathrm{R}_{f}$ : 0.53 (cyclohexane/EtOAc 9:1, visualized with $1.3 \%$ ninhydrine solution). ${ }^{1} \mathrm{H} \mathrm{NMR}\left(\mathrm{CDCl}_{3}, 500 \mathrm{MHz}, \mathrm{ppm}\right): \delta 3.99-3.76(\mathrm{~m}, 2 \mathrm{H}), 3.40(\mathrm{t}, J=6.9 \mathrm{~Hz}, 2 \mathrm{H})$, $1.88-1.81(\mathrm{~m}, 2 \mathrm{H}), 1.61-1.45(\mathrm{~m}, 15 \mathrm{H}), 1.45-1.23(\mathrm{~m}, 14 \mathrm{H}), 1.07(\mathrm{dd}, J=15.9,6.2 \mathrm{~Hz}$, 
$3 \mathrm{H}) .{ }^{13} \mathrm{C} \mathrm{NMR}\left(\mathrm{CDCl}_{3}, 126 \mathrm{MHz}, \mathrm{ppm}\right): \delta 152.11,151.79,92.64,92.19,79.91,79.28,76.56$, 76.35, 55.44, 55.42, 34.17, 32.97, 29.57, 29.53, 28.88, 28.70, 28.63, 28.30, 27.51, 25.12, 23.96, 14.46, 13.78. ESI-LCMS: $m / z$ calcd for $\mathrm{C}_{21} \mathrm{H}_{38} \mathrm{D}_{2} \mathrm{NO}_{3} \mathrm{BrNa}[\mathrm{M}+\mathrm{Na}]^{+} 458.22$; observed 458.2.

\section{Synthesis of $(4 S, 5 R)$-tert-butyl 2,2,4-trimethyl-5-(pentadec-11-yn-1-yl-1,2-d 2 )oxazolidine- 3-carboxylate (30)}

The lithated 1-pentyne was synthesized as follows; to a stirred solution of 1-pentyne $(330 \mu \mathrm{L}$, $3.3 \mathrm{mmol})$ in anhydrous THF $(7 \mathrm{~mL})$ under an argon atmosphere at $-78^{\circ} \mathrm{C}$ was carefully added a solution of $t$-BuLi $(1.8 \mathrm{~mL}, 3 \mathrm{mmol}, 1.7 \mathrm{M}$ solution in pentane) in dropwise over a period of $20 \mathrm{~min}$; the rate of addition was adjusted so as to keep the internal temperature below $-65^{\circ} \mathrm{C}$. The resulting reaction mixture was stirred at the same conditions for $2 \mathrm{~h}$ to afford lithated 1pentyne solution which was used directly in the next step.

A stirred solution of freshly prepared lithated 1-pentyne at $-78^{\circ} \mathrm{C}$ was sequentially treated with hexamethylphosphoramide $(870 \mu \mathrm{L}, 5 \mathrm{mmol})$, followed by a dropwise addition of a solution of compound 29 (470 mg, $1.1 \mathrm{mmol}, 0.25 \mathrm{M}$ solution in anhydrous THF) over a period of $20 \mathrm{~min}$. After being stirred at the same conditions for $1 \mathrm{~h}$, and for additional $12 \mathrm{~h}$ at ambient temperature (as monitored by TLC analysis; Pet. ether/ EtOAc 9:1; $\mathrm{R}_{f}$ (adduct) $=0.53 ; \mathrm{R}_{f}$ (product) $=0.64$; visualized with Seebach reagent), the reaction mixture was carefully quenched with an icecoold sat. $\mathrm{NH}_{4} \mathrm{Cl}$ solution $(80 \mathrm{~mL})$. The resulting mixture was diluted with ethylacetate $(80 \mathrm{~mL})$ and the layers were separated. The aqueous phase was extracted again with ethylacetate, and the combined organic phases were subsequently washed with sat. $\mathrm{NaHCO}_{3}$ solution and brine, dried over anhydrous $\mathrm{Na}_{2} \mathrm{SO}_{4}$, filtered, and concentrated. The obtained residue was purified by flash column chromatography over silica gel using petroleum ether and ethylacetate as eluents (from $0-15 \%$ ethylacetate in petroleum ether) to afford the desired product $\mathbf{3 0}$ as a pale yellow oil.

Yield: $265 \mathrm{mg}$ (58\%). $\mathrm{R}_{f}$ : 0.48 (Pet. ether/ EtOAc 10:1, visualized with 1.3\% ninhydrine solution). ${ }^{1} \mathrm{H}$ NMR $\left(\mathrm{CDCl}_{3}, 500 \mathrm{MHz}, \mathrm{ppm}\right): \delta 3.93-3.74(\mathrm{~m}, 2 \mathrm{H}), 2.66-2.27(\mathrm{~m}, 4 \mathrm{H}), 1.78$ $-1.64(\mathrm{~m}, 2 \mathrm{H}), 1.63-1.46(\mathrm{~m}, 17 \mathrm{H}), 1.44-1.22(\mathrm{~m}, 14 \mathrm{H}), 1.09(\mathrm{dd}, J=15.9,6.1 \mathrm{~Hz}, 3 \mathrm{H})$, 0.89 (t, $J=7.3 \mathrm{~Hz}, 3 \mathrm{H}) .{ }^{13} \mathrm{C} \mathrm{NMR}\left(\mathrm{CDCl}_{3}, 126 \mathrm{MHz}, \mathrm{ppm}\right): \delta 152.12,151.81,92.63,92.19$, 83.67, 79.89, 79.28, 77.84, 76.57, 76.37, 55.45, 55.41, 31.58, 30.34, 29.91, 29.74, 29.71, 29.67, 29.61, 29.44, 28.71, 28.63, 28.43, 27.52, 27.36, 25.12, 23.97, 23.04, 22.73, 22.11, 14.46, 13.97, 13.78. ESI-LCMS: $m / z$ calcd for $\mathrm{C}_{26} \mathrm{H}_{46} \mathrm{D}_{2} \mathrm{NO}_{3} \mathrm{Br}[\mathrm{M}+\mathrm{H}]^{+} 424.38$; observed 424.4.

\section{Synthesis of $(4 S, 5 R)-\quad$ tert-butyl 2,2,4-trimethyl-5-((Z)-pentadec-11-en-1-yl-1,2- $d_{2}$ )oxazolidine-3-carboxylate (31)}

A stirred solution of compound $\mathbf{3 0}(220 \mathrm{mg}, 0.53 \mathrm{mmol})$ in dry mixture of ethylacetate:DMF (50 mL, 95:5) under an argon atmosphere at ambient temperature was treated with a catalytic amount of Lindlar catalyst. The reaction vessel was evacuated and then backfilled with hydrogen gas (this process was repeated at least 2 times), and the resulting reaction mixture was allowed to stir at the same conditions for $16 \mathrm{~h}$ (as monitored by HPLC analysis for complete reduction). The mixture was subsequently filtered through a pad of Celite, which was rinsed 
several times with ethylacetate $(3 \times 80 \mathrm{~mL})$. The combined filtrates were concentrated under in vacuo and the obtained residue was purified by flash column chromatography over silica gel using petroleum ether and ethylacetate as eluents (from 0-10\% ethylacetate in petroleum ether) to provide the desired compound $\mathbf{3 1}$ as a colorless oil.

Yield: $155 \mathrm{mg}$ (69\%). $\mathrm{R}_{f}$. 0.47 (Pet. ether/ EtOAc 10:1, visualized with 1.3\% ninhydrine solution). ${ }^{1} \mathrm{H} \mathrm{NMR}\left(\mathrm{CDCl}_{3}, 500 \mathrm{MHz}, \mathrm{ppm}\right): \delta 35.40-5.32(\mathrm{~m}, 2 \mathrm{H}), 3.98-3.77(\mathrm{~m}, 2 \mathrm{H}), 2.04$ $-1.98(\mathrm{~m}, 4 \mathrm{H}), 1.60-1.45(\mathrm{~m}, 16 \mathrm{H}), 1.41-1.23(\mathrm{~m}, 17 \mathrm{H}), 1.08$ (dd, $J=16.1,6.2 \mathrm{~Hz}, 3 \mathrm{H})$, $0.90(\mathrm{t}, J=7.4 \mathrm{~Hz}, 3 \mathrm{H}) .{ }^{13} \mathrm{C} \mathrm{NMR}\left(\mathrm{CDCl}_{3}, 126 \mathrm{MHz}, \mathrm{ppm}\right): \delta 152.11,151.80,130.25,129.79$, $92.64,92.19,79.90,79.27,76.58,76.38,55.47,55.42,31.58,30.34,29.91,29.74,29.71,29.67$, 29.61, 29.44, 28.71, 28.63, 28.43, 27.52, 27.36, 25.12, 23.97, 23.30, 23.04, 14.46, 13.96, 13.78 . ESI-LCMS: $m / z$ calcd for $\mathrm{C}_{26} \mathrm{H}_{46} \mathrm{D}_{2} \mathrm{NO}_{3} \mathrm{Br}[\mathrm{M}+\mathrm{H}]^{+} 426.39$; observed 426.4 .

\section{Synthesis of $(2 S, 3 R, Z)$-2-aminooctadec-14-en-4,5- $d_{2}$-3-ol (32)}

To a stirred solution of compound $31(0.12 \mathrm{~g}, 0.28 \mathrm{mmol})$ in dry methanol $(3 \mathrm{~mL})$ at $0^{\circ} \mathrm{C}$ was added dropwise acetyl chloride $(200 \mu \mathrm{L}, 2.8 \mathrm{mmol})$. After being stirred at the same conditions for $30 \mathrm{~min}$, and for additional $90 \mathrm{~min}$ at ambient temperature (as monitored by TLC, visualized with $\mathrm{KMnO}_{4}$ solution), the reaction mixture was concentrated under reduced pressure. The resultant residue was taken up in diethylether $(50 \mathrm{~mL})$ and sequentially washed with saturated $\mathrm{NaHCO}_{3}$ solution $(50 \mathrm{~mL})$ and brine solution $(80 \mathrm{~mL})$, dried over anhydrous $\mathrm{Na}_{2} \mathrm{SO}_{4}$, filtered and concentrated in vacuo. Flash olumn chromatography of the obtained crude product over silica gel using ethylacetate and isopropanol as eluents (from 0-10\% isopropanol in ethylacetate) provided the desired product $\mathbf{3 2}$ as a white solid.

Yield: $62 \mathrm{mg}$ (76\%). $\mathrm{R}_{f}$. 0.46 (EtOAc/ iso-propanol 4:1, visualized with 1.3\% ninhydrine solution). ${ }^{1} \mathrm{H}$ NMR (MeOD, $\left.500 \mathrm{MHz}, \mathrm{ppm}\right): \delta 5.39-5.31(\mathrm{~m}, 2 \mathrm{H}), 3.72-3.68(\mathrm{~m}, 1 \mathrm{H}), 3.27$ $(\mathrm{qd}, J=6.8,3.0 \mathrm{~Hz}, 1 \mathrm{H}), 2.06-1.99(\mathrm{~m}, 2 \mathrm{H}), 1.46-1.28(\mathrm{~m}, 18 \mathrm{H}), 1.22(\mathrm{~d}, J=6.8 \mathrm{~Hz}, 3 \mathrm{H})$, $0.91(\mathrm{t}, J=7.4 \mathrm{~Hz}, 3 \mathrm{H}) .{ }^{13} \mathrm{C}$ NMR (MeOD, $\left.126 \mathrm{MHz}, \mathrm{ppm}\right): \delta 131.01,130.61,71.59,52.62$, 30.85, 30.73, 30.63, 30.33, 30.29, 28.12, 23.95, 14.11, 12.05. ESI-LCMS: $\mathrm{m} / \mathrm{z}$ calcd for $\mathrm{C}_{18} \mathrm{H}_{36} \mathrm{D}_{2} \mathrm{NO}[\mathrm{M}+\mathrm{H}]^{+}$286.31; observed 286.3.

\section{(S)-2-[(tert-Butoxycarbonyl)-amino]-3-hydroxypropionic acid (33)}

A stirred solution of L-serine $(2.5 \mathrm{~g}, 23.75 \mathrm{mmol})$ in aqueous $1 \mathrm{M} \mathrm{NaOH}(25 \mathrm{~mL})$ at $-15^{\circ} \mathrm{C}$ was treated with a solution of di-tert-butyldicarbonate $(6.2 \mathrm{~g}, 28.5 \mathrm{mmol})$ in dioxane $(25 \mathrm{~mL})$ dropwise over a period of $20 \mathrm{~min}$. After being stirred at the same conditions for $1 \mathrm{~h}$ and for additional $3 \mathrm{~h}$ at ambient temperature, the reaction mixture was washed two times with n-hexane $(2 \times 60 \mathrm{~mL})$ to remove excess of unreacted $\mathrm{Boc}_{2} \mathrm{O}$. The aqueous layer was then cooled to $-15^{\circ} \mathrm{C}$ and carefully acidified with a solution of $1 \mathrm{M} \mathrm{KHSO}_{4}$ (to $\mathrm{pH} \approx 2-3$ ). The resulting mixture was subsequently extracted with ethylacetate $(4 \times 80 \mathrm{~mL})$, and the combined organic extracts were dried over anhydrous $\mathrm{Na}_{2} \mathrm{SO}_{4}$, filtered and concentrated under reduced pressure to provide $\mathrm{N}$ Boc-L-serine 33 as colourless oil. The product was used in the next step without any further purification. Yield: $4.5 \mathrm{~g}$ (92\%). $\mathrm{R}_{f} .0 .2$ (EtOAc 100\%, visualized with $1.3 \%$ ninhydrine). The spectroscopic data of the product were consistent with those reported in literature ${ }^{1}$. 


\section{(S)-tert-butyl-1-( $N$-methoxy- $N$-methylcarbamoyl)-2-hydroxyethylcarbamate (34)}

To a stirred solution of $N$-Boc-L-serine $33(3 \mathrm{~g}, 14.6 \mathrm{mmol})$ in dry DCM $(30 \mathrm{~mL})$ at $-15^{\circ} \mathrm{C}$ under argon atmosphere was added $N, O$-dimethylhydroxylamine hydrochloride $(1.6 \mathrm{~g}, 16.1$ mmol), followed by addition of $N$-methylmorpholine $(1.8 \mathrm{~mL}, 16.1 \mathrm{mmol}$, until $\mathrm{pH} \approx 8-9)$. To the resulting mixture, 1-ethyl-3-(3-dimethylaminopropyl)-carbodiimide hydrochloride (EDCI.HCl) (3.1 g, $16.1 \mathrm{mmol}$ ) was added portionwise over a period of $30 \mathrm{~min}$. After the resulting reaction mixture was allowed to stir for $90 \mathrm{~min}$ at $-15^{\circ} \mathrm{C}$ (as judged by TLC analysis, EtOAc $100 \% ; \mathrm{R}_{f(a d d u c t)}=0.2 ; \mathrm{R}_{f(\text { product })}=0.5$; visualized with $1.3 \%$ ninhydrine), an ice-cold $1 \mathrm{M}$ $\mathrm{HCl}$ solution $(100 \mathrm{~mL})$ was carefully added to quench the reaction. The resulting mixture was subsequently diluted with $\mathrm{CH}_{2} \mathrm{Cl}_{2}(100 \mathrm{~mL})$ and the layers were separated. The aqueous layer was extracted with $\mathrm{CH}_{2} \mathrm{Cl}_{2}(3 \times 80 \mathrm{~mL})$. The combined organic layers were sequentially washed with saturated $\mathrm{NaHCO}_{3}$ solution $(100 \mathrm{~mL})$ and brine $(100 \mathrm{~mL})$, dried over anhydrous $\mathrm{Na}_{2} \mathrm{SO}_{4}$, filtered and concentrated under reduced pressure to provide compound $\mathbf{3 4}$ as a white solid. The product was used in the next step without any further purification ${ }^{1}$.

Yield: $3.1 \mathrm{~g},(86 \%) . \mathrm{R}_{f}: 0.16$ (EtOAc $100 \%$, visualized with $1.3 \%$ ninhydrine). ${ }^{1} \mathrm{H} \mathrm{NMR}\left(\mathrm{CDCl}_{3}\right.$, $500 \mathrm{MHz}, \mathrm{ppm}): \delta 1.44$ (s, 9H), $3.22(\mathrm{~s}, 3 \mathrm{H}), 3.77$ (s, 3H), 3.80-3.82 (m, 2H), 4.79 (b.s, 1H), $5.65(\mathrm{~d}, J=5.7 \mathrm{~Hz}, 1 \mathrm{H}),{ }^{13} \mathrm{C}-\mathrm{NMR}\left(\mathrm{CDCl}_{3}, 125 \mathrm{MHz}, \mathrm{ppm}\right) \delta 28.4,32.2,52.5,61.7,63.8,80.2$, 156.0, 171.1. ESI-HRMS $m / z$ calcd for $\mathrm{C}_{10} \mathrm{H}_{20} \mathrm{~N}_{2} \mathrm{O}_{5} \mathrm{Na}[\mathrm{M}+\mathrm{Na}]^{+} 271.1269$; observed 271.1264.

\section{(S)-tert-Butyl-(1-hydroxy-3-oxopent-4-en-2-yl)carbamate (35)}

To a stirred solution of compound $34(1.45 \mathrm{~g}, 5.9 \mathrm{mmol})$ in dry THF $(30 \mathrm{~mL})$ at $-78^{\circ} \mathrm{C}$ under argon atmosphere was added dropwise a solution of n-butyllithium $(n-\mathrm{BuLi}, 2.1 \mathrm{~mL}, 5.3 \mathrm{mmol}$, $2.5 \mathrm{M}$ in hexane). The resulting mixture was stirred at the same conditions for $30 \mathrm{~min}$, before a solution of vinylmagnesium bromide $(14.8 \mathrm{~mL}, 14.8 \mathrm{mmol}, 1 \mathrm{M}$ solution in THF) was added dropwise; the addition rate was adjusted so as to keep the internal temperature at $-40^{\circ} \mathrm{C}$ and it took $25 \mathrm{~min}$ to complete. After being stirred at $-40^{\circ} \mathrm{C}$ for $30 \mathrm{~min}$, gradually warmed to ambient temperature and stirred for additional $4 \mathrm{~h}$ (as monitored by TLC analysis), the reaction mixture was added dropwise to an ice-cold $1 \mathrm{M} \mathrm{HCl}$ solution $(100 \mathrm{~mL})$ to quench; again so as to keep the internal temperature below $-10^{\circ} \mathrm{C}$ and it took $30 \mathrm{~min}$ to complete. The resultant mixture was subsequently diluted with ethylacetate $(100 \mathrm{~mL})$ and the layers were separated. The aqueous layer was extracted several times with ethylacetate $(4 \times 80 \mathrm{~mL})$. The combined organic extracts were washed with saturated $\mathrm{NaHCO}_{3}$ solution $(150 \mathrm{~mL})$ and brine $(150 \mathrm{~mL})$, dried over anhydrous $\mathrm{Na}_{2} \mathrm{SO}_{4}$, filtered and concentrated under reduced pressure. Flash column chromatography of the resultant crude mixture over silica gel using cyclohexane and ethylacetate as eluents (from 25-40\% ethylacetate in cyclohexane) afforded compound $\mathbf{3 5}$ as a colorless oil.

Yield: $920 \mathrm{mg}$, (73\%). $\mathrm{R}_{f}$ : 0.45 (Cyclohexane/ EtOAc 1:1, visualized with 1.3\% ninhydrine). ${ }^{1} \mathrm{H} \mathrm{NMR}\left(\mathrm{CDCl}_{3}, 500 \mathrm{MHz}, \mathrm{ppm}\right): \delta 6.57(\mathrm{dd}, J=17.4,10.5 \mathrm{~Hz}, 1 \mathrm{H}), 6.44(\mathrm{dd}, J=17.5,1.0 \mathrm{~Hz}$, $1 \mathrm{H}), 5.93(\mathrm{~d}, J=10.5 \mathrm{~Hz}, 1 \mathrm{H}), 5.69$ (br.s, $1 \mathrm{H}), 4.66(\mathrm{~m}, 1 \mathrm{H}), 3.95(\mathrm{dd}, J=11.6,3.6 \mathrm{~Hz}, 1 \mathrm{H})$, $3.90(\mathrm{dd}, J=11.6,4.2 \mathrm{~Hz}, 1 \mathrm{H}), 1.46(\mathrm{~s}, 9 \mathrm{H}) .{ }^{13} \mathrm{C} \mathrm{NMR}\left(\mathrm{CDCl}_{3}, 125 \mathrm{MHz}, \mathrm{ppm}\right): \delta 196.4,156.1$, 132.7, 130.7, 80.4, 63.6, 59.9, 28.3. ESI-MS $m / z(\mathrm{M}+\mathrm{H})^{+} 216.1$.

(2S,4E)-tert-Butyl -(1-hydroxy-3-oxooctadec-4-en-2-yl)carbamate (36) 
To a stirred solution of compound 35 (155 mg, $0.72 \mathrm{mmol})$ in dry DCM (4 mL) under argon atmosphere was added 1-pentadecene $(782 \mu \mathrm{L}, 2.9 \mathrm{mmol})$, followed by a catalytic amount of Grubbs Catalyst $2^{\text {nd }}$ Generation (as a solid in one portion, $7 \mathrm{~mol} \%$ ). The resulting reaction mixture was allowed to stir under reflux and was monitored by TLC analysis until no further change in the composition of the reaction mixture (6h, visualized with $\mathrm{KMNO}_{4}$ ). The solvent was subsequently removed under reduced pressure and the resultant residue was directly purified by flash column chromatography over silica gel using cyclohexane and ethylacetate as eluents (from 20-27\% ethylacetate in cyclohexane) to afford the desired product $\mathbf{3 6}$ as a yellow oil.

Yield: $190 \mathrm{mg}$ (67\%). $\mathrm{R}_{f}: 0.62$ (cyclohexane/ethylacetate 3:2, visualized with $1.3 \%$ ninhydrine solution). ${ }^{1} \mathrm{H}$ NMR $\left(\mathrm{CDCl}_{3}, 500 \mathrm{MHz}, \mathrm{ppm}\right): \delta 7.06$ (dt, $\left.J=15.7,6.9 \mathrm{~Hz}, 1 \mathrm{H}\right), 6.27(\mathrm{~d}, J=15.7$ Hz, 1H), 5.73 (br.s, 1H), 4.62 (s, 1H), 3.93 (dd, $J=11.5,3.4 \mathrm{~Hz}, 1 \mathrm{H}), 3.85$ (dd, $J=11.5,4.5$ $\mathrm{Hz}, 1 \mathrm{H}), 2.27-2.22(\mathrm{~m}, 2 \mathrm{H}), 1.45(\mathrm{~s}, 9 \mathrm{H}), 1.33-1.24(\mathrm{~m}, 22 \mathrm{H}), 0.87(\mathrm{t}, J=7.0 \mathrm{~Hz}, 3 \mathrm{H}) .{ }^{13} \mathrm{C}$ NMR $\left(\mathrm{CDCl}_{3}, 125 \mathrm{MHz}, \mathrm{ppm}\right): \delta 195.9,156.4,151.2,126.5,80.5,64.5,60.1,32.9,32.1,22.8$, 14.3. ESI-MS $m / z,(\mathrm{M}+\mathrm{H})^{+} 398.4$.

\section{(2S)-2-amino-1-hydroxyoctadecan-3-one-4,5-d2 (37)}

A stirred solution of compound 36 (100 $\mathrm{mg}, 0.25 \mathrm{mmol})$ in anhydrous d-chloroform $(5 \mathrm{~mL})$ under an argon atmosphere at ambient temperature was treated with a catalytic amount of $10 \%$ $\mathrm{Pd} / \mathrm{C}(6 \mathrm{mg})$ followed by 2-drops of d-acetic acid. After being evacuated, the reaction vessel was backfilled with deuterium gas and the resulting heterogeneous reaction mixture was allowed to stir for $16 \mathrm{~h}$ at the same conditions. The suspension was subsequently filtered through a short pad of Celite, which was rinsed several times with chloroform $(3 \times 50 \mathrm{~mL})$. The filtrates were combined and concentrated under reduced pressure to afford $\mathrm{N}$-Boc-3-ketosphinganine$\mathrm{d}_{2}$ as an oily residue. The obtained residue was dissolved in methanol $(15 \mathrm{~mL})$ and subsequently treated with $4 \mathrm{~N} \mathrm{HCl-THF} \mathrm{solution}(3 \mathrm{~mL})$. After the resulting reaction mixture was allowed to stir under reflux for $2 \mathrm{~h}$ (as monitored by TLC analysis; cyclohexane / EtOAc 3:2; $\mathrm{R}_{f}$ (adduct) $=$ $0.62 ; \mathrm{R}_{f}$ (product) $=0.01$; visualized with $1.3 \%$ ninhydrine solution), the solvent was removed under reduced pressure. The obtained residue was taken up in $n$-hexane $(5 \mathrm{~mL})$ and the mixture was vigorously stirred for $30 \mathrm{~min}$, during while a white precipitate was formed. The obtained white precipitate was filtered off and subsequently washed with ice-cold diethylether to provide the desired product $\mathbf{3 7}$ as a white solid.

Yield: $46 \mathrm{mg}$ (63\%, over 2 steps). $\mathrm{R}_{f}$ : 0.32 (EtOAc/ iso-propanol 10:1, visualized with 1.3\% ninhydrine solution). ${ }^{1} \mathrm{H}$ NMR (MeOD, $500 \mathrm{MHz}, \mathrm{ppm}$ ): $\delta 4.18$ (t, $J=3.8 \mathrm{~Hz}, 1 \mathrm{H}$ ), 4.10 (dd, $J$ $=12.1,4.2 \mathrm{~Hz}, 1 \mathrm{H}), 3.98(\mathrm{dd}, J=12.1,3.5 \mathrm{~Hz}, 1 \mathrm{H}), 2.62(\mathrm{dd}, J=14.1,7.1 \mathrm{~Hz}, 1 \mathrm{H}), 1.60(\mathrm{~m}$, $1 \mathrm{H}), 1.30(\mathrm{~m}, 24 \mathrm{H}), 0.90(\mathrm{t}, J=7.0 \mathrm{~Hz}, 3 \mathrm{H}) .{ }^{13} \mathrm{C} \mathrm{NMR}$ (MeOD, $\left.126 \mathrm{MHz}, \mathrm{ppm}\right): \delta 205.3,62.2$, $60.2,33.1,30.8,30.7,30.6,30.5,30.4,29.9,23.7,14.4$. ESI-MS $m / z(\mathrm{M}+\mathrm{H})^{+} 302.4$.

\section{1-((tetrahydro-2H-pyran-2-yl)oxy)undecan-1-ol (38)}

A stirred solution of 1,11-undecandiol (11.8 g, $63 \mathrm{mmol})$ in dry tetrahydrofuran $(200 \mathrm{~mL})$ at $0^{\circ} \mathrm{C}$ under argon atmosphere was treated with a catalytic amount of $p$-toluenesulfonic acid 
monohydrate (PTSA) (0.95 g, $5.04 \mathrm{mmol}, 8 \mathrm{~mol} \%$ ), followed by dropwise addition of 3,4dihydropyran solution (5.9 mL, $69.3 \mathrm{mmol}, 1 \mathrm{M}$ in dry THF). After being stirred at the same conditions for $1 \mathrm{~h}$, gradually warmed to ambient temperature and stirred for additional $16 \mathrm{~h}$ (as judged by TLC analysis; cyclohexane/ EtOAc 6:4; $\mathrm{R}_{f \text { (adduct) }}=0.36 ; \mathrm{R}_{f}$ (product) $=0.67$; visualized with ceric ammonium molybdate solution), the reaction mixture was diluted with diethylether $(100 \mathrm{~mL})$ and carefully quenched at $0^{\circ} \mathrm{C}$ with saturated aqueous $\mathrm{NaHCO}_{3}$ solution $(150 \mathrm{~mL})$. The layers were separated and the aqueous layer was extracted with diethylether $(3 \times 100 \mathrm{~mL})$. The combined organic extracts was washed with brine solution $(200 \mathrm{~mL})$, dried over anhydrous $\mathrm{Na}_{2} \mathrm{SO}_{4}$, filtered and concentrated in vacuo. Purification of the obtained crude product by flash column chromatography over silica gel using cyclohexane and ethylacetate as eluents (from 18$26 \%$ ethylacetate in cyclohexane) provided compound $\mathbf{3 8}$ as colorless oil ${ }^{2,3}$.

Yield: $9.6 \mathrm{~g}$ (56\%; note, the di-protected diol byproduct was isolated in $\sim 6 \%$ yield). $\mathrm{R}_{f}: 0.52$ (cyclohexane/EtOAc 7:3, ceric ammonium molybdate solution). ${ }^{1} \mathrm{H} \mathrm{NMR}\left(500 \mathrm{MHz}, \mathrm{CDCl}_{3}\right.$, ppm) $\delta 4.53(1 \mathrm{H}, \mathrm{t}, J=3.2 \mathrm{~Hz}), 3.75-3.71(\mathrm{~m}, 2 \mathrm{H}), 3.67-3.62(\mathrm{~m}, 2 \mathrm{H}), 3.46(2 \mathrm{H}, \mathrm{t}, J=6.5 \mathrm{~Hz})$, $1.86-1.69(\mathrm{~m}, 8 \mathrm{H}), 1.61-1.23(\mathrm{~m}, 16 \mathrm{H}) .{ }^{13} \mathrm{C} \mathrm{NMR}\left(126 \mathrm{MHz}, \mathrm{CDCl}_{3}, \mathrm{ppm}\right) \delta 98.79,67.61$, $62.87,62.17,32.67,30.64,29.72,29.60,29.52,29.49,29.38,29.33,26.17,25.67,25.43,19.52$. MS $\left(\mathrm{ESI}^{+}\right) \mathrm{m} / z$ calcd for $\mathrm{C}_{16} \mathrm{H}_{33} \mathrm{O}_{3}[\mathrm{M}+\mathrm{H}]^{+} 273.24$; observed 273.2.

\section{2-((11-bromoundecyl)oxy)tetrahydro-2H-pyran (39)}

To a stirred solution of alcohol $38(9.1 \mathrm{~g}, 33.52 \mathrm{mmol})$ and $\mathrm{CBr}_{4}(12.2 \mathrm{~g}, 36.9 \mathrm{mmol})$ in anhydrous dichloromethane $(335 \mathrm{~mL})$ at $0^{\circ} \mathrm{C}$ under an argon atmosphere was added dropwise a solution of triphenyl phosphine $(10.1 \mathrm{~g}, 38.5 \mathrm{mmol}, 39 \mathrm{~mL} 1 \mathrm{M}$ in dry dichloromethane) over a period of $20 \mathrm{~min}$. After the resulting reaction mixture was allowed to stir for $1 \mathrm{~h}$ at $0^{\circ} \mathrm{C}$, gradually warmed to ambient temperature, and stirred for additional $3 \mathrm{~h}$ (as monitored by TLC analysis; Pet. ether/ EtOAc 8:2; $\mathrm{R}_{f}$ (adduct) $=0.37 ; \mathrm{R}_{f}$ (product) $=0.68 ;$ visualized with ceric ammonium molybdate solution), the solvent was removed under reduced pressure. The resultant oily residue was suspended in petroleum ether $(100 \mathrm{~mL})$ and the mixture was stirred for $30 \mathrm{~min}$ at ambient temperature, during while a white precipitate was formed. The mixture was filtered through a pad of Celite to remove the formed triphenylphosphonium oxide and the combined filtrates was concentrated under reduced pressure. This process was repeated several times until no further precipitate was formed. The obtained oily crude product was subsequently purified by flash column chromatography over silica gel using petroleum ether and ethylacetate as eluents (from 5-15\% ethylacetate in petroleum ether) to yield compound $\mathbf{3 9}$ as colorless oil.

Yield: $9.64 \mathrm{~g}(86 \%) . \mathrm{R}_{f} .0 .53$ (petroleum ether /EtOAc 9:1, ceric ammonium molybdate solution). These data are in accordance with literature precedence ${ }^{2,3} .{ }^{1} \mathrm{H}$ NMR $(500 \mathrm{MHz}$, $\left.\mathrm{CDCl}_{3}, \mathrm{ppm}\right) \delta$ 4.59-4.56 (m, 1H), 3.92-3.86 (m, 1H), 3.76-3.69 (m, 1H), 3.54-3.49 (m, $\left.1 \mathrm{H}\right)$, $3.42(\mathrm{t}, J=7.1 \mathrm{~Hz}, 2 \mathrm{H}), 3.39-3.36(\mathrm{~m}, 1 \mathrm{H}), 1.89-1.52(\mathrm{~m}, 8 \mathrm{H}), 1.42-1.27(\mathrm{~m}, 16 \mathrm{H}) .{ }^{13} \mathrm{C} \mathrm{NMR}$ (126 MHz, $\left.\mathrm{CDCl}_{3}, \mathrm{ppm}\right) \delta 98.96,67.82,62.46,34.12,32.89,30.84,29.92,29.73,29.61,29.57$, 28.90, 28.24, 26.37, 25.64, 19.76. MS $\left(\mathrm{ESI}^{+}\right) \mathrm{m} / \mathrm{z}$ calcd for $\mathrm{C}_{16} \mathrm{H}_{32} \mathrm{O}_{2} \mathrm{Br}[\mathrm{M}+\mathrm{H}]^{+} 335.16$; observed 335.2. 


\section{2-(undec-10-en-1-yloxy)-tetrahydro-2H-pyran (40)}

To a stirred solution of compound 39 (9.4 g, $28.3 \mathrm{mmol})$ in anhydrous THF (280 mL) at ambient temperature under an argon atmosphere was added tert-BuOK (3.5 g, $31.13 \mathrm{mmol})$ in portionwise over a period of $30 \mathrm{~min}$. After being stirred under reflux for $12 \mathrm{~h}$ (as monitored by TLC analysis, cyclohexane/EtOAc 95:5; $\mathrm{R}_{f(a d d u c t)}=0.4 ; \mathrm{R}_{f(\text { product })}=0.58$; visualized with ceric ammonium molybdate solution), the reaction was cooled to room temperature and subsequently quenched with water $(200 \mathrm{~mL})$. The layers were separated and the aqueous layer was extracted with petroleum ether $(3 \times 100 \mathrm{~mL})$. The combined organic extracts were washed with brine (200 $\mathrm{mL}$ ), dried over anhydrous $\mathrm{Na}_{2} \mathrm{SO}_{4}$, filtered and concentrated in vacuo. Purification of the resultant oil by flash column chromatography over silica gel using petroleum ether and ethylacetate as eluents (from 0-9\% ethylacetate in petroleum ether) provided compound $\mathbf{4 0}$ as colorless oil.

Yield: $4.6 \mathrm{~g}(64 \%) . \mathrm{R}_{f}$ : 0.67 (Pet. ether/ EtOAc 9:1, visualized with ceric ammonium molybdate solution). ${ }^{1} \mathrm{H}-\mathrm{NMR}\left(126 \mathrm{MHz}, \mathrm{CDCl}_{3}, \mathrm{ppm}\right.$ ): 5.81 (ddt, $J=16.9,6.7,1.3 \mathrm{~Hz}, 1 \mathrm{H}$ ), 5.12-4.93 (m, 2H), 4.58-4.54 (m, 1H), 3.89-3.69 (m, $2 \mathrm{H}), 3.64-3.31$ (m, 2H), 2.11-1.98 (m, $2 \mathrm{H}), 1.89-1.65(\mathrm{~m}, 2 \mathrm{H}), 1.64-1.46(\mathrm{~m}, 6 \mathrm{H}), 1.44-1.27(\mathrm{~m}, 12 \mathrm{H}) .{ }^{13} \mathrm{C}-\mathrm{NMR}\left(126 \mathrm{MHz}, \mathrm{CDCl}_{3}\right.$, ppm): 139.17, 113.79, 98.84, 67.65, 62.24, 33.87, 30.76, 29.69, 29.56, 29.37, 29.14, 28.75, 26.24, 25.53, 19.56. ESI-MS $m / z$ calcd for $\mathrm{C}_{16} \mathrm{H}_{31} \mathrm{O}_{2}[\mathrm{M}+\mathrm{H}]^{+}:$255.23; observed 255.2.

\section{Undec-10-en-1-ol (41)}

A stirred solution of compound $40(4.4 \mathrm{~g}, 17.1 \mathrm{mmol})$ in ethanol $(85 \mathrm{~mL})$ at ambient temperature was treated with a catalytic amount of pyridinium $p$-toluenesulfonate (PPTS) $(0.43 \mathrm{~g}, 1.71$ $\mathrm{mmol}, 10 \mathrm{~mol} \%)$. After the resulting reaction mixture was allowed to stir under reflux for $2 \mathrm{~h}$ (as judged by TLC analysis for almost a complete deprotection; Pet. ether/ EtOAc 9:1; $\mathrm{R}_{f}$ (adduct) $=0.67 ; \mathrm{R}_{f \text { (product) }}=0.39$; visualized with ceric ammonium molybdate solution), the solvent was removed under reduced pressure. The resultant oily residue was diluted with diethylether $(100 \mathrm{~mL})$ and subsequently washed with saturated $\mathrm{NaHCO}_{3}$ solution $(100 \mathrm{~mL})$. The aqueous layer was extracted again with diethylether $(3 \times 80 \mathrm{~mL})$, and the combined organic extracts were washed with brine $(150 \mathrm{~mL})$, dried over anhydrous $\mathrm{Na}_{2} \mathrm{SO}_{4}$, filtered and concentrated in vacuo. The obtained crude product was purified by flash column chromatography over silica gel using cyclohexane and ethylacetate as eluents (from 15-20\% ethylacetate in cyclohexane) to furnish compound $\mathbf{4 1}$ as colorless oil.

Yield: $2.3 \mathrm{~g}(79 \%)$. Rf: 0.48 (Pet. ether/ EtOAc 4:1, visualized with ceric ammonium molybdate solution). ${ }^{1} \mathrm{H}$ NMR (500 MHz, $\left.\mathrm{CDCl}_{3}, \mathrm{ppm}\right) \delta 5.81$ (ddt, $J=16.9,10.2,6.7 \mathrm{~Hz}, 1 \mathrm{H}$ ), 4.99 (ddd, $J=17.1,3.7,1.6 \mathrm{~Hz}, 1 \mathrm{H}), 4.92(\mathrm{ddt}, J=10.2,2.3,1.2 \mathrm{~Hz}, 1 \mathrm{H}), 3.63(\mathrm{t}, J=6.7 \mathrm{~Hz}, 2 \mathrm{H}), 2.06-$ $2.01(\mathrm{~m}, 2 \mathrm{H}), 1.56(\mathrm{dq}, J=13.4,6.7 \mathrm{~Hz}, 2 \mathrm{H}), 1.42-1.26(\mathrm{~m}, 12 \mathrm{H}) .{ }^{13} \mathrm{C}$ NMR $(126 \mathrm{MHz}$, $\left.\mathrm{CDCl}_{3}, \mathrm{ppm}\right) \delta 139.37,114.25,63.21,33.94,32.93,29.68,29.55,29.25,29.06,25.87$. ESI-MS $m / z$ calcd for $\mathrm{C}_{11} \mathrm{H}_{23} \mathrm{O}[\mathrm{M}+\mathrm{H}]^{+}:$171.17; observed 171.2.

\section{1-bromoundec-1-ene (42)}


A stirred solution of 10-undecenol 41 (1.05 g, $6.15 \mathrm{mmol})$ and $\mathrm{CBr}_{4}(2.25 \mathrm{~g}, 6.8 \mathrm{mmol})$ in dry dichloromethane $(62 \mathrm{~mL})$ at $0^{\circ} \mathrm{C}$ under an argon atmosphere was treated with a solution of triphenyl phosphine (1.85 g, $7.1 \mathrm{mmol}, 7 \mathrm{~mL} 1 \mathrm{M}$ in dry dichloromethane) dropwise over a period of $20 \mathrm{~min}$. The resulting reaction mixture was allowed to stir at the same conditions for $1 \mathrm{~h}$ and for additional $3 \mathrm{~h}$ at ambient temperature (as judged by TLC analysis; Pet. ether/ EtOAc $4: 1 ; \mathrm{R}_{f}$ (adduct) $=0.48 ; \mathrm{R}_{f}$ (product) $=1$; visualized with $\mathrm{KMnO}_{4}$ solution), before it was filtered through a pad of silica gel and rinsed subsequently with petroleum ether. The combined filtrates was concentrated under reduced pressure and the resultant oily crude product was purified by flash column chromatography over silica gel using petroleum ether as eluent to afford 11bromoundec-1-ene $\mathbf{4 2}$ as colorless oil.

Yield: $1.3 \mathrm{~g}(91 \%) . \mathrm{R}_{f}$ : 0.57 (Pet. ether, visualized with $\mathrm{KMnO}_{4}$ solution). ${ }^{1} \mathrm{H}$ NMR $(500 \mathrm{MHz}$, $\left.\mathrm{CDCl}_{3}, \mathrm{ppm}\right) \delta 5.82$ (ddt, $\left.J=16.7,6.8 \mathrm{~Hz}, 1 \mathrm{H}\right), 4.96$ (ddd, $J=17.1,3.7,1.6 \mathrm{~Hz}, 1 \mathrm{H}$ ), 4.93 (ddt, $J=10.2 \mathrm{~Hz}, 1 \mathrm{H}), 3.43(\mathrm{t}, J=6.8 \mathrm{~Hz}, 2 \mathrm{H}), 2.14-2.05(\mathrm{~m}, 2 \mathrm{H}), 1.96-1.88(\mathrm{~m}, 2 \mathrm{H}),, 1.47-1.26(\mathrm{~m}$, $10 \mathrm{H}) .{ }^{13} \mathrm{C} \mathrm{NMR}\left(126 \mathrm{MHz}, \mathrm{CDCl}_{3}, \mathrm{ppm}\right) \delta 139.31,114.32,34.13,33.91,32.96,29.57,29.23$, $29.04,28.96,28.47$.

\section{Undec-10-en-1-yl 4-methylbenzenesulfonate (43)}

A stirred solution of 10-undecenol $41(1.1 \mathrm{~g}, 6.25 \mathrm{mmol})$ in dry dichloromethane $(16 \mathrm{~mL})$ under argon atmosphere at $0^{\circ} \mathrm{C}$ was treated with pyridine $(2 \mathrm{~mL}, 25 \mathrm{mmol})$, followed by a portionwise addition of tosyl chloride $(1.5 \mathrm{~g}, 7.8 \mathrm{mmol})$. After being stirred at the same condition for $1 \mathrm{~h}$ and for additional $16 \mathrm{~h}$ at ambient temperature (as monitored by TLC analysis; Pet. ether/ EtOAc $4: 1 ; \mathrm{R}_{f \text { (adduct) }}=0.48 ; \mathrm{R}_{f \text { (product) }}=0.77$; visualized with $\mathrm{KMnO}_{4}$ solution), the reaction mixture was diluted with $\mathrm{CH}_{2} \mathrm{Cl}_{2}(100 \mathrm{~mL})$ and carefully quenched with saturated $\mathrm{NaHCO}_{3}$ solution (100 $\mathrm{mL}$ ). The layers were separated and the aqueous layer was extracted several times with $\mathrm{CH}_{2} \mathrm{Cl}_{2}$ ( $3 \times \mathrm{x} 80 \mathrm{~mL}$ ). The combined organic layers were successively washed with saturated $\mathrm{CuSO}_{4}$ solution $(150 \mathrm{~mL})$ and brine $(150 \mathrm{~mL})$, dried over anhydrous $\mathrm{Na}_{2} \mathrm{SO}_{4}$, filtered and concentrated under reduced pressure. Flash column chromatography of the resultant crude product over silica gel using petroleum ether and ethylacetate as eluents (from 0-10\% ethylacetate in petroleum ether) afforded the desired product $\mathbf{4 3}$ as white waxy solid.

Yield: $1.7 \mathrm{~g}(84 \%)$. $\mathrm{R}_{f}$. 0.57 (petroleum ether /EtOAc 9:1, visualized with $\mathrm{KMnO}_{4}$ solution). ${ }^{1} \mathrm{H}$ NMR $\left(500 \mathrm{MHz}, \mathrm{CDCl}_{3}, \mathrm{ppm}\right) \delta 4.58(\mathrm{dd}, J=4.4,2.8 \mathrm{~Hz}, 1 \mathrm{H}), 3.88(\mathrm{ddd}, J=11.1,7.0,3.9$ $\mathrm{Hz}, 1 \mathrm{H}), 3.74(\mathrm{dt}, J=9.6,6.9 \mathrm{~Hz}, 1 \mathrm{H}), 3.50(\mathrm{ddd}, J=8.1,6.5,4.6 \mathrm{~Hz}, 1 \mathrm{H}), 3.46-3.34(\mathrm{~m}, 3 \mathrm{H})$, 1.92-1.78 (m, 3H), 1.79-1.66 (m, 1H), 1.63-1.49 (m, 6H), 1.46-1.25 (m, 12H). ${ }^{13} \mathrm{C} \mathrm{NMR} \mathrm{(126}$ $\left.\mathrm{MHz}, \mathrm{CDCl}_{3}, \mathrm{ppm}\right) \delta 99.01,67.82,62.52,34.22,32.97,30.93,29.88,29.60,29.57,29.51$, 28.88, 28.30, 26.36, 25.65, 19.86. ESI-MS $m / z$ calcd for $\mathrm{C}_{18} \mathrm{H}_{28} \mathrm{NaO}_{3} \mathrm{~S}[\mathrm{M}+\mathrm{Na}]^{+}: 347.17$; observed 347.2.

\section{(S)-2-methylbutyl 4-methylbenzenesulfonate (44)}

To a stirred solution of $(S)$-2-methylbutan-1-ol (2 g, $22.4 \mathrm{mmol})$ in dry dichloromethane (45 $\mathrm{mL}$ ) under argon atmosphere at $0^{\circ} \mathrm{C}$ was added pyridine $(7.2 \mathrm{~mL}, 89.6 \mathrm{mmol})$, followed by a portionwise addition of tosyl chloride $(5.3 \mathrm{~g}, 28 \mathrm{mmol})$. The resulting reaction mixture was 
allowed to stir for $4 \mathrm{~h}$ at ambient temperature (as monitored by TLC analysis; Pet. ether/ EtOAc $7: 3 ; \mathrm{R}_{f}$ (adduct) $=0.38 ; \mathrm{R}_{f}$ (product) $=0.79$; visualized with ceric ammonium molybdate solution), before it was carefully quenched with saturated $\mathrm{NaHCO}_{3}$ solution $(100 \mathrm{~mL})$. The resultant mixture was extracted with n-pentane $(3 \times 100 \mathrm{~mL})$ and the combined organic layers were washed with saturated $\mathrm{CuSO}_{4}$ solution $(150 \mathrm{~mL})$ and brine $(150 \mathrm{~mL})$, dried over anhydrous $\mathrm{Na}_{2} \mathrm{SO}_{4}$, filtered and concentrated (Caution: temperature of rotatory evaporator shouldn't exceed $35^{\circ} \mathrm{C}$ ). Purification of the crude product with flash column chromatography over silica gel using n-pentane and ethylacetate as eluents (from 0-9\% ethylacetate in petroleum ether) afforded the desired product $\mathbf{4 4}$ as colorless oil.

Yield: $3.9 \mathrm{~g}(72 \%)$. $\mathrm{R}_{f}: 0.53$ (petroleum ether /EtOAc 9:1, ceric ammonium molybdate solution). ${ }^{1} \mathrm{H}$ NMR $\left(300 \mathrm{MHz}, \mathrm{CDCl}_{3}, \mathrm{ppm}\right) \delta 7.82(\mathrm{~d}, J=8.5 \mathrm{~Hz}, 2 \mathrm{H}), 7.36(\mathrm{~d}, J=8.1 \mathrm{~Hz}, 2 \mathrm{H})$, $3.74(\mathrm{~d}, J=6.1 \mathrm{~Hz}, 2 \mathrm{H}), 2.46(\mathrm{~s}, 3 \mathrm{H}), 1.74-1.61(\mathrm{~m}, 1 \mathrm{H}), 1.48-1.09(\mathrm{~m}, 2 \mathrm{H}), 0.86(\mathrm{~d}, J=6.9$, $3 \mathrm{H}), 0.82(\mathrm{t}, J=7.5 \mathrm{~Hz}, 3 \mathrm{H})$. ESI-MS $\mathrm{m} / z$ calcd for $\mathrm{C}_{12} \mathrm{H}_{18} \mathrm{NaO}_{3} \mathrm{~S}[\mathrm{M}+\mathrm{Na}]^{+}: 265.09$; observed 265.1.

\section{(S)-1-bromo-2-methylbutane (45)}

A stirred solution of (S)-2-methylbutyl 4-methylbenzenesulfonate $44(3.1 \mathrm{~g}, 12.7 \mathrm{mmol})$ and $N$-bromosuccinimide (NBS) $(2.5 \mathrm{~g}, 14 \mathrm{mmol})$ in anhydrous dichloromethane $(125 \mathrm{~mL})$ at $0^{\circ} \mathrm{C}$ under argon atmosphere was treated with a solution of triphenyl phosphine $\left(\mathrm{PPh}_{3}\right)(3.8 \mathrm{~g}, 14.6$ $\mathrm{mmol})$ in anhydrous dichloromethane $(15 \mathrm{~mL})$ over a period of $20 \mathrm{~min}$. After the resulting reaction mixture was allowed to stir for $2 \mathrm{~h}$ at ambient temperature (as judged by TLC analysis for almost a complete reaction, Pet. ether/ EtOAc 9:1; $\mathrm{R}_{f \text { (adduct) }}=0.53 ; \mathrm{R}_{f}$ (product) $=1$; visualized with $\mathrm{KMnO}_{4}$ solution), the reaction mixture was filtered through a pad of silica gel and rinsed subsequently with n-pentane. The solvent was removed under reduced pressure (Caution: temperature of rotatory evaporator shouldn't exceed $25^{\circ} \mathrm{C}$ ), and the resultant residue was subsequently purified by flash column chromatography over silica gel using n-pentane as eluent to furnish the desired compound $\mathbf{4 5}$ as colorless oil.

Yield: $1.3 \mathrm{~g}(68 \%)$. $\mathrm{R}_{f} 0.57$ (petroleum ether, visualized with $\mathrm{KMnO}_{4}$ solution). ${ }^{1} \mathrm{H}$ NMR (500 $\left.\mathrm{MHz}, \mathrm{CDCl}_{3}, \mathrm{ppm}\right) \delta 3.41(\mathrm{dd}, J=9.8 \mathrm{~Hz}, 1 \mathrm{H}), 3.37(\mathrm{dd}, J=9.8,5.6 \mathrm{~Hz}, 1 \mathrm{H}), 1.79-1.71(\mathrm{~m}, 1$ H), 1.56-1.44 (m, 1H), $1.26(\mathrm{q}, J=7.4 \mathrm{~Hz}, 1 \mathrm{H}) 1.02(\mathrm{~d}, J=6.7 \mathrm{~Hz}, 3 \mathrm{H}), 0.93(\mathrm{t}, J=7.6 \mathrm{~Hz}, 3 \mathrm{H})$. ${ }^{13} \mathrm{C}$ NMR $\left(126 \mathrm{MHz}, \mathrm{CDCl}_{3}, \mathrm{ppm}\right) \delta 41.25,37.18,27.63,18.74,11.36$.

\section{(S)-13-methylpentadec-1-ene (47)}

The Grignard reagent of (S)-1-bromo-2-methylbutane (46) was synthesized as follows; A mixture of magnesium turnings $(0.3 \mathrm{~g}, 12.5 \mathrm{mmol})$ in anhydrous THF $(3 \mathrm{~mL})$ under an argon atmosphere was treated with 2 drops of 1,2-dibromoethane (in order to activate the magnesium), followed by a solution of $(S)$-1-bromo-2-methylbutane $(1.2 \mathrm{~g}, 8.3 \mathrm{mmol}$, in $5 \mathrm{~mL}$ of anhydrous THF). After the reaction had begun, the reaction mixture was allowed to stir for $90 \mathrm{~min}$ at $30^{\circ} \mathrm{C}$ to yield a transparent Grignard solution which was immediately used in the next step.

Coupling reaction: According to Effenberger and Heid ${ }^{4}$, and Tamura and Kochi ${ }^{5}$ with some modifications. To a stirred solution of tosylate $\mathbf{4 3}(0.9 \mathrm{~g}, 2.8 \mathrm{mmol})$ in anhydrous THF $(25 \mathrm{~mL})$ 
under argon atmosphere at $-78^{\circ} \mathrm{C}$ was added dropwise a catalytic amount of dilithium tetrachlorocuprate $\left(\mathrm{Li}_{2} \mathrm{CuCl}_{4}\right)$ solution $(1.4 \mathrm{~mL}, 0.1 \mathrm{M}$ in THF). The resulting mixture was stirred for $10 \mathrm{~min}$ at the same conditions, before a freshly prepared Grignard solution $\mathbf{4 6}$ was added dropwise over a period of $20 \mathrm{~min}$. After the resulting reaction mixture was allowed to stir at ambient temperature for $16 \mathrm{~h}$, during while a dark solution formed, (as monitored by TLC analysis; Pet. ether/ EtOAc 9:1; $\mathrm{R}_{f \text { (adduct) }}=0.57 ; \mathrm{R}_{f \text { (product) }}=1$; visualized with $\mathrm{KMnO}_{4}$ solution), the reaction mixture was cooled to $0^{\circ} \mathrm{C}$ and successfully quenched with an ice-cold saturated $\mathrm{NH}_{4} \mathrm{Cl}$ solution $(100 \mathrm{~mL})$. The resulting mixture was diluted with $\mathrm{n}$-pentane $(100 \mathrm{~mL})$, and the layers were separated. The aqueous layer was extracted with n-pentane $(3 \times 50 \mathrm{~mL})$, and the combined organic layers were washed with brine, dried over anhydrous $\mathrm{Na}_{2} \mathrm{SO}_{4}$, filtered, and concentrated in vacuo (Caution: temperature of rotatory evaporator shouldn't exceed $25^{\circ} \mathrm{C}$ ). Purification of the obtained crude mixture by flash column chromatography over silica gel using n-pentane as eluent afforded the desired product $\mathbf{4 7}$ as colorless oil.

Yield: $0.42 \mathrm{~g}(49 \%) . \mathrm{R}_{f} 0.59$ (Pet. ether, visualized with $\mathrm{KMnO}_{4}$ solution). ${ }^{1} \mathrm{H} \mathrm{NMR}(500 \mathrm{MHz}$, $\left.\mathrm{CDCl}_{3}, \mathrm{ppm}\right) \delta 5.82(\mathrm{ddt}, J=16.9,10.2,6.7 \mathrm{~Hz}, 1 \mathrm{H}), 4.99(\mathrm{ddd}, J=17.1,3.7,1.6 \mathrm{~Hz}, 1 \mathrm{H}), 4.93$ (ddt, $J=10.2,2.3,1.2 \mathrm{~Hz}, 1 \mathrm{H}), 2.07-2.02(\mathrm{~m}, 2 \mathrm{H}), 1.40-1.25(\mathrm{~m}, 26 \mathrm{H}), 1.17-1.07(\mathrm{~m}, 6 \mathrm{H})$, $0.88-0.83(\mathrm{~m}, 19 \mathrm{H}) .{ }^{13} \mathrm{C} \mathrm{NMR}\left(126 \mathrm{MHz}, \mathrm{CDCl}_{3}, \mathrm{ppm}\right) \delta 139.44,114.22,36.81,34.87,34.57$, $34.09,33.99,30.19,29.88,29.84,29.78,29.67,29.67,29.32,29.12,27.28,19.37,11.59,11.56$.

\section{(4S,5R)-tert-Butyl-4-(hydroxymethyl)-2,2-dimethyl-5-vinyloxazolidine-3-carboxylate (48)}

The titled compound was synthesized in 7 steps starting from L-serine according to our previously established route ${ }^{1}$. $\mathrm{R}_{f}$. 0.5 (cyclohexane/EtOAc 6:4, visualized with $1.3 \%$ ninhydrine). ${ }^{1} \mathrm{H}$ NMR $\left(\mathrm{CDCl}_{3}, 500 \mathrm{MHz}, \mathrm{ppm}\right) \delta$ 5.94-5.76 (m, $\left.1 \mathrm{H}\right)$, 5.37-5.28 (m, $\left.1 \mathrm{H}\right)$, 5.23$5.19(\mathrm{~m}, 1 \mathrm{H}), 4.54-4.48(\mathrm{~m}, 1 \mathrm{H}), 3.93-3.75(\mathrm{~m}, 1 \mathrm{H}), 3.56(\mathrm{dd}, J=5.8,11.1 \mathrm{~Hz}, 1 \mathrm{H}), 3.37(\mathrm{~m}$,

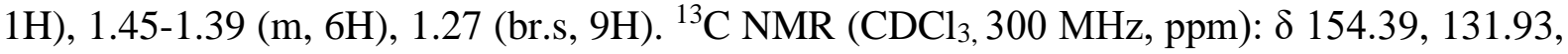
119.31, 93.27, 81.32, 76.47, 63.51, 61.85, 28.49, 24.79. MS (ESI $\left.{ }^{+}\right) \mathrm{m} / z$ calcd for $\mathrm{C}_{13} \mathrm{H}_{23} \mathrm{NNaO}_{4}$ $[\mathrm{M}+\mathrm{Na}]^{+} 280.15$; observed 280.1 .

\section{$(4 S, 5 R)$-tert-butyl -4-(hydroxymethyl)-2,2-dimethyl-5-( $(S, E)-13$-methylpentadec-1-en-1- yl)oxazolidine-3-carboxylate (49)}

To a stirred solution of compound 48 (82 mg, $0.32 \mathrm{mmol}$.) in dry dichloromethane $(3 \mathrm{~mL})$, under argon atmosphere, was added the cross partner $47(0.36 \mathrm{~g}, 1.6 \mathrm{mmol})$, followed by a catalytic amount of (1,3-bis(2,4,6-trimethylphenyl)-2-imidazolidinylidene)-dichloro(phenylmethylene) (tricyclohexylphosphine)-ruthenium, Grubbs catalyst $2^{\text {nd }}$ generation, 8 mol\%). After the resulting reaction mixture was allowed to stir under reflux for $12 \mathrm{~h}$ (until the TLC analysis showed no further change in the composition of the reaction mixture; Pet. ether/ EtOAc 7:3; $\mathrm{R}_{f \text { (adduct) }}=0.45 ; \mathrm{R}_{f}$ (product) $=0.6$; visualized with $1.3 \%$ ninhydrine), the solvent was removed under reduced pressure. The resultant crude residue was subsequently purified by flash column chromatography over silica gel using cyclohexane and ethylacetate as eluents (from 20$25 \%$ ethylacetate in cyclohexane) to afford the desired product $\mathbf{4 9}$ as pale yellow oil. 
Yield: $88 \mathrm{mg}$ (61.4\%). $\mathrm{R}_{f}: 0.48$ (cyclohexane/ethylacetate 8:2, visualized with $1.3 \%$ ninhydrine). ${ }^{1} \mathrm{H}$ NMR $\left(\mathrm{CDCl}_{3}, 500 \mathrm{MHz}, \mathrm{ppm}\right): \delta 5.92-5.84(\mathrm{~m}, 1 \mathrm{H}), 5.63-5.41(\mathrm{~m}, 1 \mathrm{H})$, $4.57(\mathrm{t}, J=6.5 \mathrm{~Hz}, 1 \mathrm{H}), 4.11-4.04(\mathrm{~m}, 1 \mathrm{H}), 3.89-3.43(\mathrm{~m}, 3 \mathrm{H}), 2.06(\mathrm{dd}, J=10.3,6.4 \mathrm{~Hz}$, $2 \mathrm{H}), 1.67-1.46(\mathrm{~m}, 15 \mathrm{H}), 1.42-1.25(\mathrm{~m}, 21 \mathrm{H}), 1.16-1.07(\mathrm{~m}, 2 \mathrm{H}), 0.87-0.82(\mathrm{~m}, 6 \mathrm{H}) .{ }^{13} \mathrm{C}$ NMR $\left(\mathrm{CDCl}_{3}, 125 \mathrm{MHz}, \mathrm{ppm}\right): \delta 154.59,137.56,123.37,93.10,81.36,80.41,63.93,62.19$, 36.79, 34.55, 32.53, 30.17, 29.85, 29.82, 29.72, 29.65, 29.60, 29.38, 28.55, 27.26, 19.37, 11.56. ESI-MS $m / z$ calcd for $\mathrm{C}_{27} \mathrm{H}_{52} \mathrm{NO}_{4}[\mathrm{M}+\mathrm{H}]^{+}$: 454.39; observed 454.4.

\section{$(2 S, 3 R, 16 S, E)$-2-amino-16-methyloctadec-4-ene-1,3-diol (50)}

A stirred solution of compound $49(65 \mathrm{mg}, 0.14 \mathrm{mmol})$ in absolute methanol $(1.5 \mathrm{~mL})$ at $0^{\circ} \mathrm{C}$ was carefully treated with acetyl chloride in dropwise ( $\mathrm{AcCl}, 150 \mu \mathrm{L}, 2.1 \mathrm{mmol}$ ). After the resulting reaction mixture was allowed to stir at the same conditions for $30 \mathrm{~min}$ and for additional $90 \mathrm{~min}$ at ambient temperature (as detected by TLC analysis for complete deprotection), the solvent was removed under reduced pressure. The resultant waxy residue was washed with ice-cooled diethylether and subsequently filtered off to provide the desired crude product as a colorless waxy solid. Further purification of the obtained crude product was performed by flash column chromatography over silica gel using ethylacetate and isopropanol as eluents (from 0-5\% isopropanol in ethylacetate) to afford compound $\mathbf{5 0}$ as a white waxy solid.

Yield: $36 \mathrm{mg}(82 \%) . \mathrm{R}_{f}$. 0.31 (EtOAc/ iso-propanol 9:1, visualized with $\mathrm{KMnO}_{4}$ solution). ${ }^{1} \mathrm{H}$ NMR (MeOD, $500 \mathrm{MHz}, \mathrm{ppm}) \delta 5.88$ (ddd, $J=14.9,7.2,3.8 \mathrm{~Hz}, 1 \mathrm{H}), 5.53-5.47(\mathrm{~m}, 1 \mathrm{H})$, $4.34-4.30(\mathrm{~m}, 1 \mathrm{H}), 3.82(\mathrm{dd}, J=11.6,4.0 \mathrm{~Hz}, 1 \mathrm{H}), 3.69$ (dd, $J=11.6,8.3 \mathrm{~Hz}, 1 \mathrm{H}), 3.23$ (dt, $J=8.5,4.3 \mathrm{~Hz}, 1 \mathrm{H}), 2.13(\mathrm{q}, J=7.0 \mathrm{~Hz}, 2 \mathrm{H}), 1.48-1.43(\mathrm{~m}, 2 \mathrm{H}), 1.40-1.30(\mathrm{~m}, 16 \mathrm{H}), 1.20$ $-1.11(\mathrm{~m}, 2 \mathrm{H}), 0.92-0.87(\mathrm{~m}, 6 \mathrm{H}) .{ }^{13} \mathrm{C} \mathrm{NMR}(\mathrm{MeOD}, 125 \mathrm{MHz}, \mathrm{ppm}) \delta 136.54,128.46$, 70.95, 59.42, 58.54, 37.78, 35.69, 33.35, 31.10, 30.80, 30.78, 30.73, 30.63, 30.59, 30.36, 30.17, 28.19, 19.63, 11.74. ESI-MS $m / z$ calcd for $\mathrm{C}_{19} \mathrm{H}_{40} \mathrm{NO}_{2}[\mathrm{M}+\mathrm{H}]^{+}:$314.31; observed 314.3. 


\section{References}

[1] T. Kolter, K. Sandhoff, Sphingolipids - Their Metabolic Pathways and the Pathobiochemistry of Neurodegenerative Diseases, Angewandte Chemie International Edition, 38 (1999) 1532-1568.

[2] A.C. Carreira, T.C. Santos, M.A. Lone, E. Zupancic, E. Lloyd-Evans, R.F.M. de Almeida, T. Hornemann, L.C. Silva, Mammalian sphingoid bases: Biophysical, physiological and pathological properties, Prog Lipid Res, (2019) 100995.

[3] O. Quehenberger, A.M. Armando, A.H. Brown, S.B. Milne, D.S. Myers, A.H. Merrill, S. Bandyopadhyay, K.N. Jones, S. Kelly, R.L. Shaner, C.M. Sullards, E. Wang, R.C. Murphy, R.M. Barkley, T.J. Leiker, C.R. Raetz, Z. Guan, G.M. Laird, D.A. Six, D.W. Russell, J.G. McDonald, S. Subramaniam, E. Fahy, E.A. Dennis, Lipidomics reveals a remarkable diversity of lipids in human plasma, J Lipid Res, 51 (2010) 3299-3305.

[4] S.T. Pruett, A. Bushnev, K. Hagedorn, M. Adiga, C.A. Haynes, M.C. Sullards, D.C. Liotta, A.H. Merrill, Jr., Biodiversity of sphingoid bases ("sphingosines") and related amino alcohols, J Lipid Res, 49 (2008) 1621-1639.

[5] R. Rollin-Pinheiro, A. Singh, E. Barreto-Bergter, M. Del Poeta, Sphingolipids as targets for treatment of fungal infections, Future Med Chem, 8 (2016) 1469-1484.

[6] L.J. Heung, C. Luberto, M. Del Poeta, Role of sphingolipids in microbial pathogenesis, Infect Immun, 74 (2006) 28-39.

[7] A. Penno, M.M. Reilly, H. Houlden, M. Laura, K. Rentsch, V. Niederkofler, E.T. Stoeckli, G. Nicholson, F. Eichler, R.H. Brown, Jr., A. von Eckardstein, T. Hornemann, Hereditary sensory neuropathy type 1 is caused by the accumulation of two neurotoxic sphingolipids, The Journal of biological chemistry, 285 (2010) 11178-11187.

[8] A. Rotthier, M. Auer-Grumbach, K. Janssens, J. Baets, A. Penno, L. Almeida-Souza, K. Van Hoof, A. Jacobs, E. De Vriendt, B. Schlotter-Weigel, W. Loscher, P. Vondracek, P. Seeman, P. De Jonghe, P. Van Dijck, A. Jordanova, T. Hornemann, V. Timmerman, Mutations in the SPTLC2 subunit of serine palmitoyltransferase cause hereditary sensory and autonomic neuropathy type I, Am J Hum Genet, 87 (2010) 513-522.

[9] A. Othman, M.F. Rutti, D. Ernst, C.H. Saely, P. Rein, H. Drexel, C. Porretta-Serapiglia, G. Lauria, R. Bianchi, A. von Eckardstein, T. Hornemann, Plasma deoxysphingolipids: a novel class of biomarkers for the metabolic syndrome?, Diabetologia, 55 (2012) 421-431.

[10] N. Wei, J. Pan, R. Pop-Busui, A. Othman, I. Alecu, T. Hornemann, F.S. Eichler, Altered sphingoid base profiles in type 1 compared to type 2 diabetes, Lipids Health Dis, 13 (2014) 161.

[11] B. Weiss, W. Stoffel, Human and murine serine-palmitoyl-CoA transferase--cloning, expression and characterization of the key enzyme in sphingolipid synthesis, Eur J Biochem, 249 (1997) 239-247.

[12] T. Hornemann, S. Richard, M.F. Rutti, Y. Wei, A. von Eckardstein, Cloning and initial characterization of a new subunit for mammalian serine-palmitoyltransferase, The Journal of biological chemistry, 281 (2006) 37275-37281.

[13] D.K. Breslow, S.R. Collins, B. Bodenmiller, R. Aebersold, K. Simons, A. Shevchenko, C.S. Ejsing, J.S. Weissman, Orm family proteins mediate sphingolipid homeostasis, Nature, 463 (2010) 1048-1053.

[14] K. Gable, H. Slife, D. Bacikova, E. Monaghan, T.M. Dunn, Tsc3p is an 80-amino acid protein associated with serine palmitoyltransferase and required for optimal enzyme activity, The Journal of biological chemistry, 275 (2000) 7597-7603.

[15] L. Zhao, S. Spassieva, K. Gable, S.D. Gupta, L.Y. Shi, J. Wang, J. Bielawski, W.L. Hicks, M.P. Krebs, J. Naggert, Y.A. Hannun, T.M. Dunn, P.M. Nishina, Elevation of 20-carbon long chain bases due to a mutation in serine palmitoyltransferase small subunit $b$ results in neurodegeneration, Proc Natl Acad Sci U S A, 112 (2015) 12962-12967.

[16] J. Ren, E.M. Saied, A. Zhong, J. Snider, C. Ruiz, C. Arenz, L.M. Obeid, G.D. Girnun, Y.A. Hannun, Tsc3 regulates SPT amino acid choice in Saccharomyces cerevisiae by promoting alanine in the sphingolipid pathway, J Lipid Res, 59 (2018) 2126-2139. 
[17] A. Othman, C.H. Saely, A. Muendlein, A. Vonbank, H. Drexel, A. von Eckardstein, T. Hornemann, Plasma 1-deoxysphingolipids are predictive biomarkers for type 2 diabetes mellitus, BMJ Open Diabetes Res Care, 3 (2015) e000073.

[18] R. Steiner, E.M. Saied, A. Othman, C. Arenz, A.T. Maccarone, B.L. Poad, S.J. Blanksby, A. von Eckardstein, T. Hornemann, Elucidating the chemical structure of native 1-deoxysphingosine, J Lipid Res, 57 (2016) 1194-1203.

[19] G. Karsai, M. Lone, Z. Kutalik, J.T. Brenna, H. Li, D. Pan, A. von Eckardstein, T. Hornemann, FADS3 is a Delta14Z sphingoid base desaturase that contributes to gender differences in the human plasma sphingolipidome, The Journal of biological chemistry, 295 (2020) 1889-1897.

[20] I. Alecu, A. Othman, A. Penno, E.M. Saied, C. Arenz, A. von Eckardstein, T. Hornemann, Cytotoxic 1-deoxysphingolipids are metabolized by a cytochrome P450-dependent pathway, J Lipid Res, 58 (2017) 60-71.

[21] P. Garner, J.M. Park, Journal of Organic Chemistry, 52 (1987) 2361-2364.

[22] P.P. Garner, J. M.; Malecki, E. , Journal of Organic Chemistry, 53 (1988) 4395-4398.

[23] T. Yamamoto, H. Hasegawa, T. Hakogi, S. Katsumura, Versatile synthetic method for sphingolipids and functionalized sphingosine derivatives via olefin cross metathesis, Org Lett, 8 (2006) 5569-5572.

[24] P. Wisse, M.A. de Geus, G. Cross, A.M. van den Nieuwendijk, E.J. van Rooden, R.J. van den Berg, J.M. Aerts, G.A. van der Marel, J.D. Codee, H.S. Overkleeft, Synthesis of 6-Hydroxysphingosine and alpha-Hydroxy Ceramide Using a Cross-Metathesis Strategy, J Org Chem, 80 (2015) 7258-7265. [25] K.P. Bhabak, A. Hauser, S. Redmer, S. Banhart, D. Heuer, C. Arenz, Development of a novel FRET probe for the real-time determination of ceramidase activity, Chembiochem, 14 (2013) 1049-1052. [26] P. Sanllehi, M. Casasampere, J.L. Abad, G. Fabrias, O. Lopez, J. Bujons, J. Casas, A. Delgado, The first fluorogenic sensor for sphingosine-1-phosphate lyase activity in intact cells, Chem Commun (Camb), 53 (2017) 5441-5444.

[27] S. Banhart, E.M. Saied, A. Martini, S. Koch, L. Aeberhard, K. Madela, C. Arenz, D. Heuer, Improved plaque assay identifies a novel anti-Chlamydia ceramide derivative with altered intracellular localization, Antimicrob Agents Chemother, 58 (2014) 5537-5546.

[28] E.M. Saied, S. Banhart, S.E. Burkle, D. Heuer, C. Arenz, A series of ceramide analogs modified at the 1-position with potent activity against the intracellular growth of Chlamydia trachomatis, Future Med Chem, 7 (2015) 1971-1980.

[29] E.M. Saied, T.L. Le, T. Hornemann, C. Arenz, Synthesis and characterization of some atypical sphingoid bases, Bioorg Med Chem, 26 (2018) 4047-4057.

[30] C. Michel, G. van Echten-Deckert, J. Rother, K. Sandhoff, E. Wang, A.H. Merrill, Jr., Characterization of ceramide synthesis. A dihydroceramide desaturase introduces the 4,5-transdouble bond of sphingosine at the level of dihydroceramide, The Journal of biological chemistry, 272 (1997) 22432-22437.

[31] E.M. Saied, S. Banhart, S.E. Bürkle, D. Heuer, C. Arenz, A series of ceramide analogs modified at the 1-position with potent activity against the intracellular growth of Chlamydia trachomatis, Future Med Chem, (2015). 
6 NMR spectra of synthesized compounds
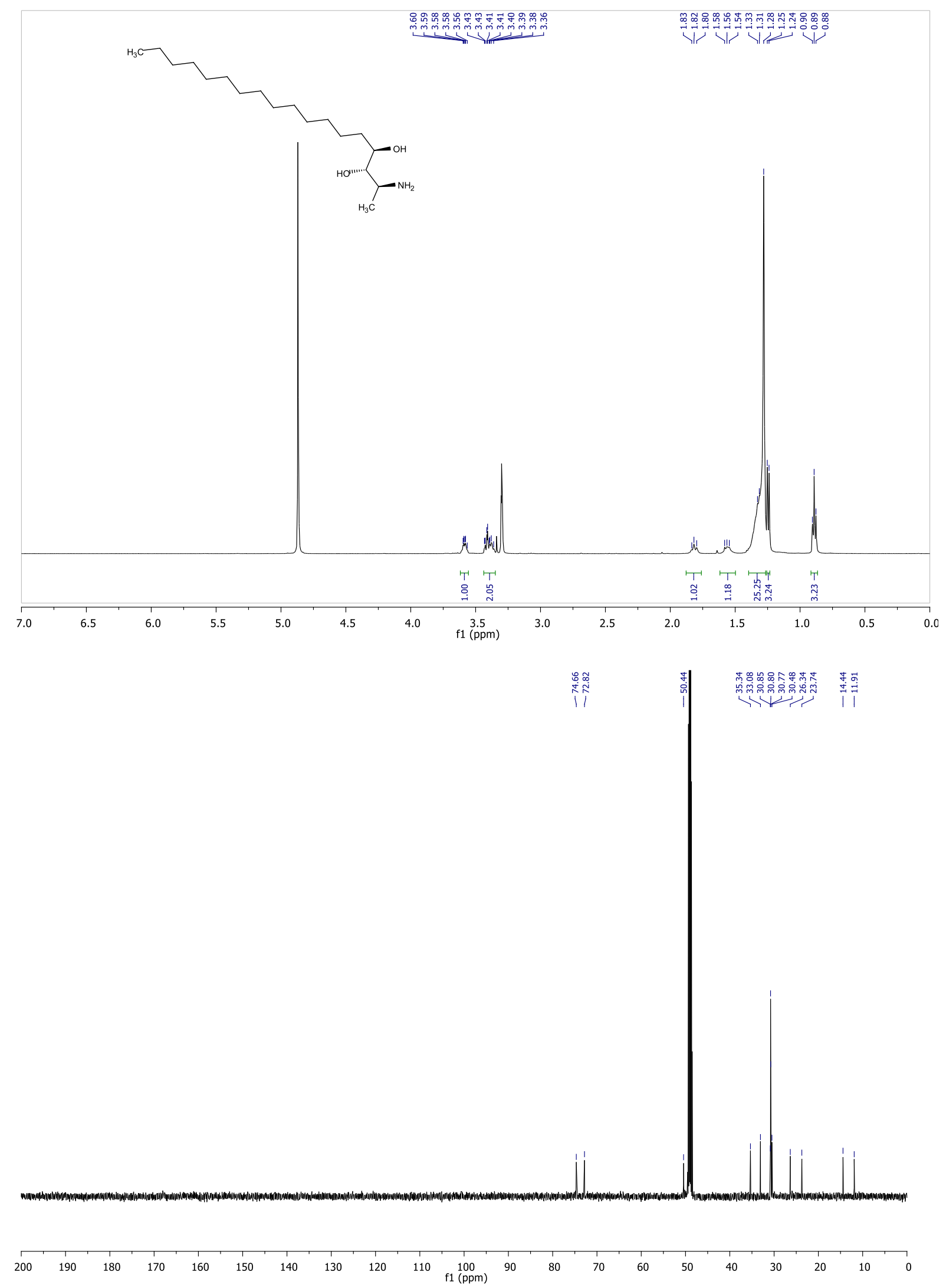

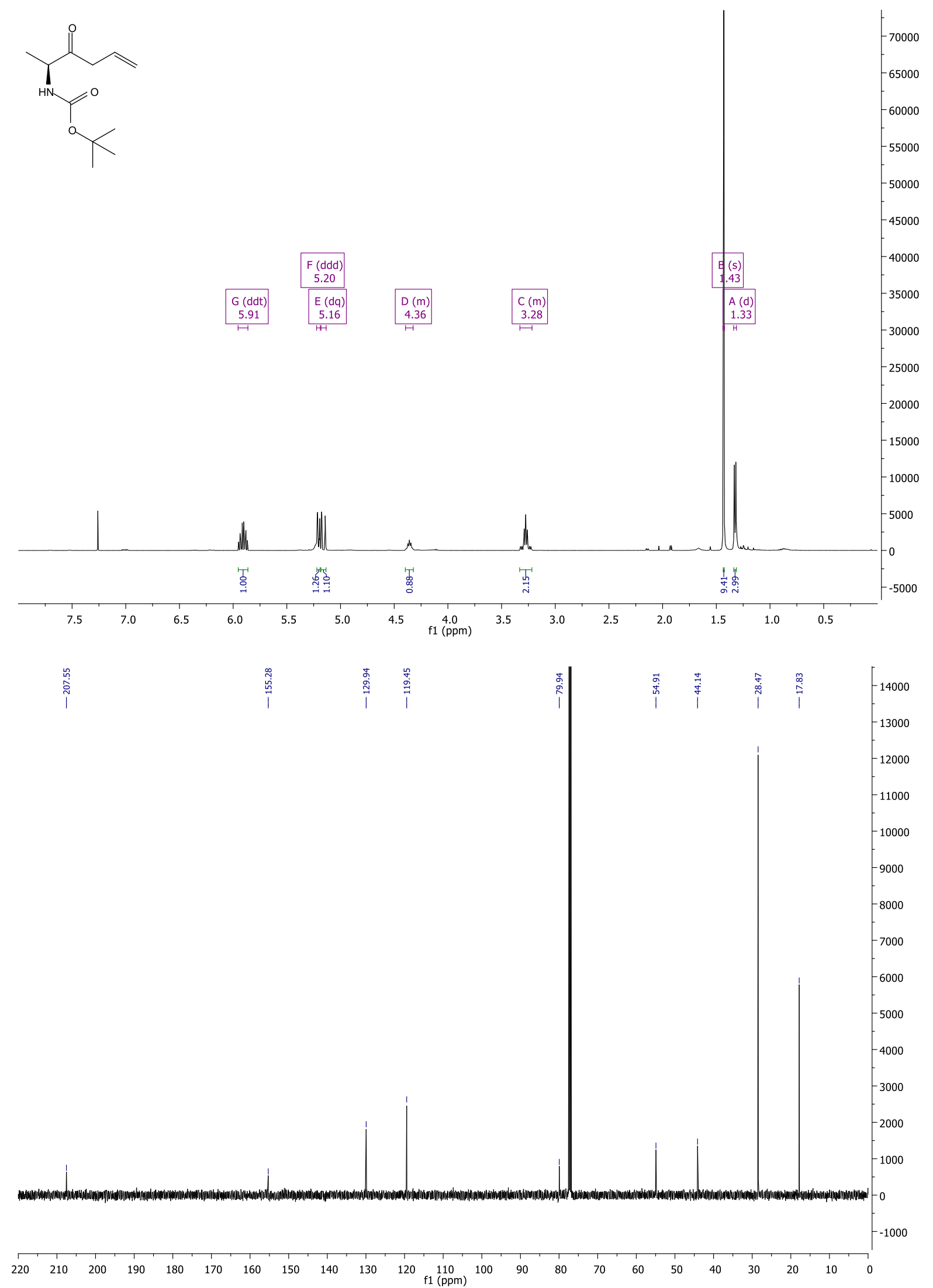

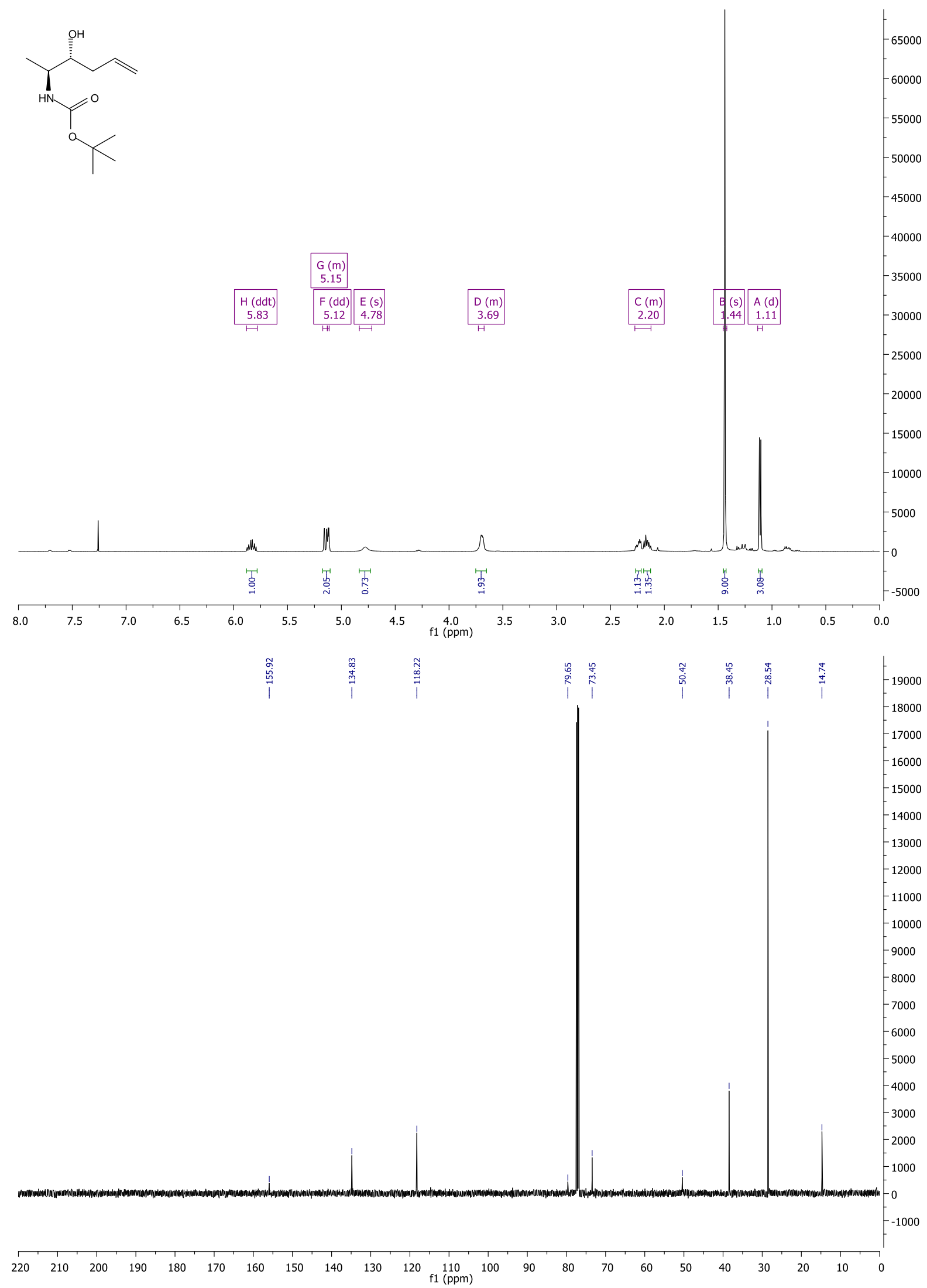

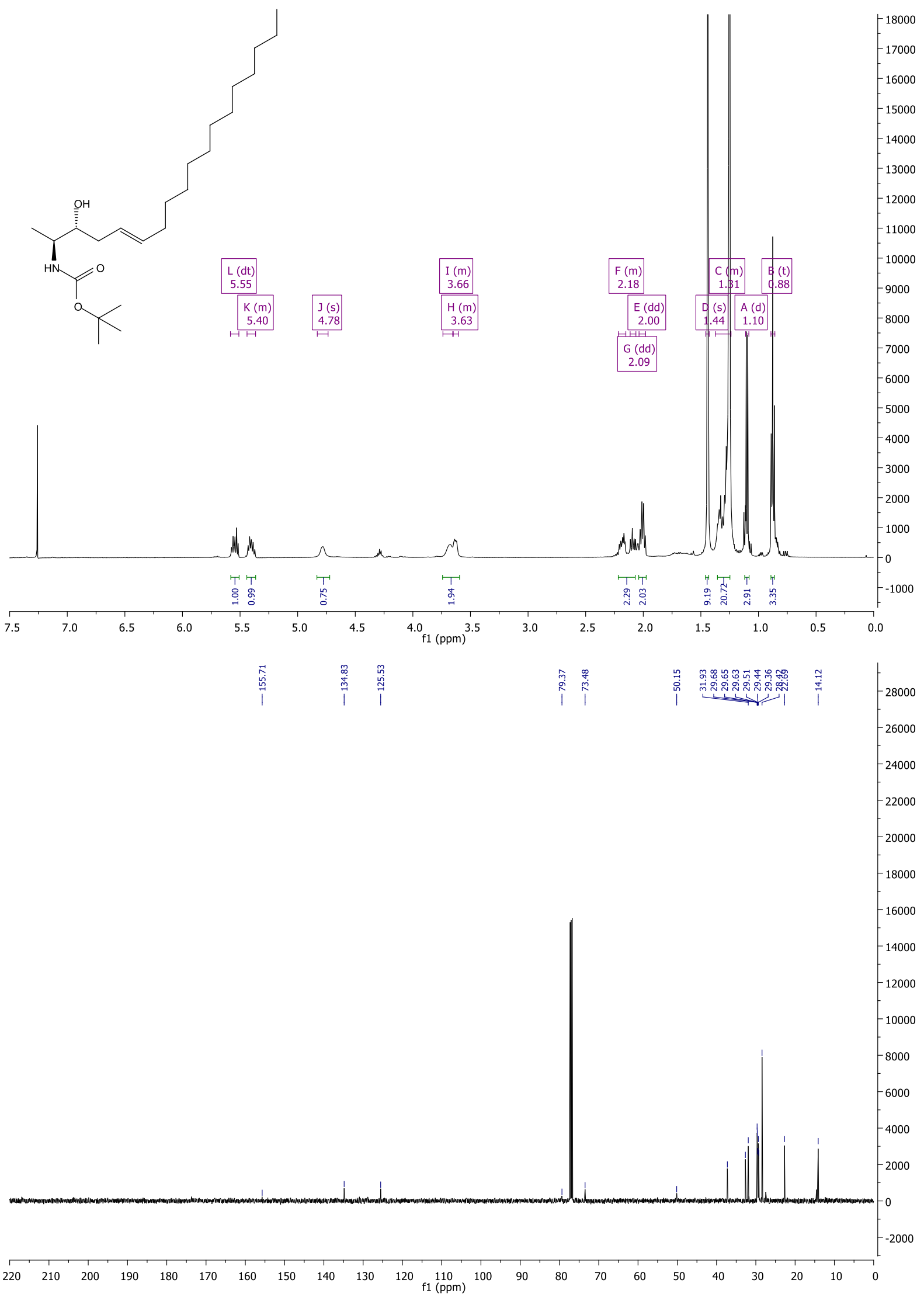

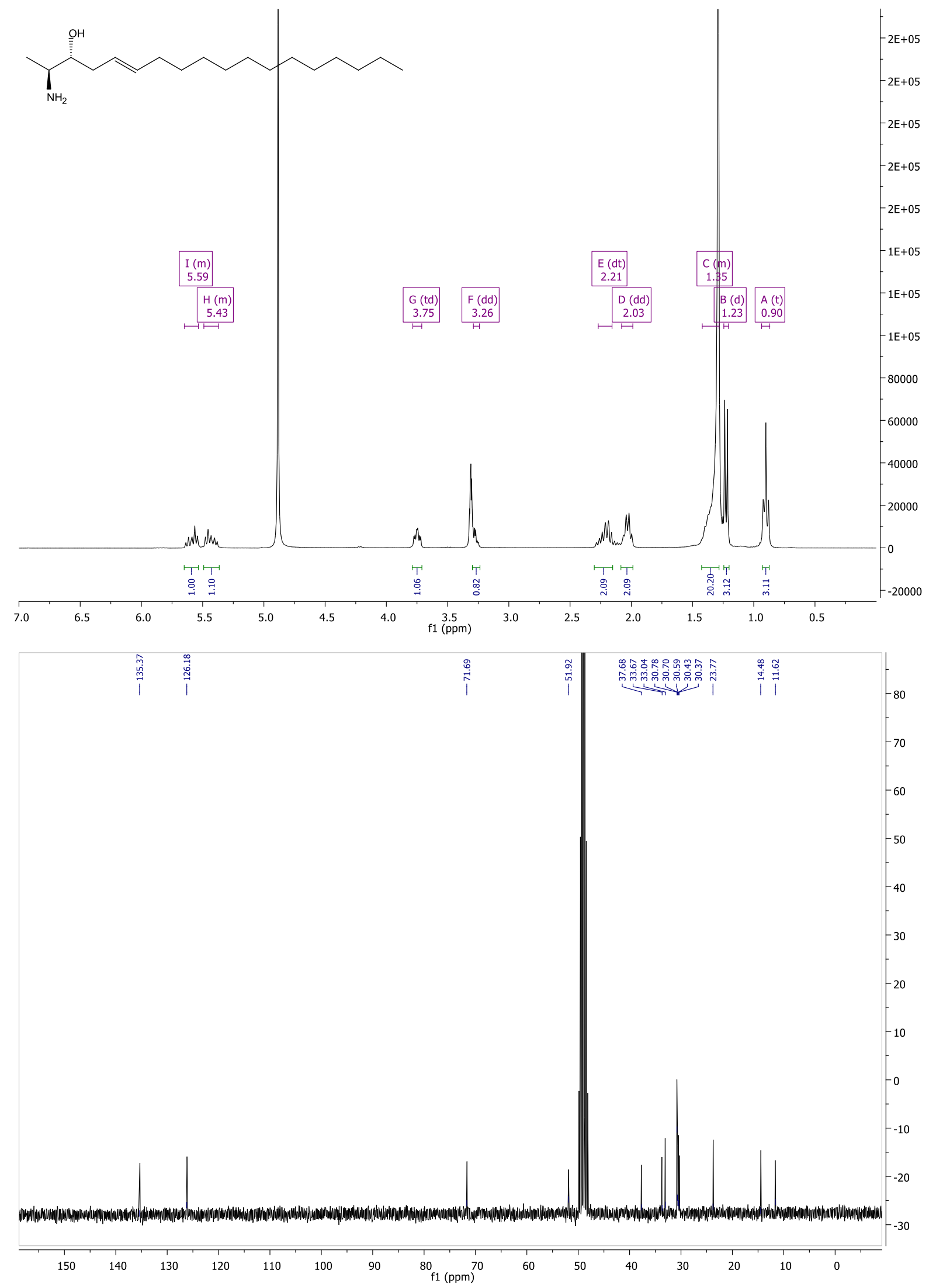

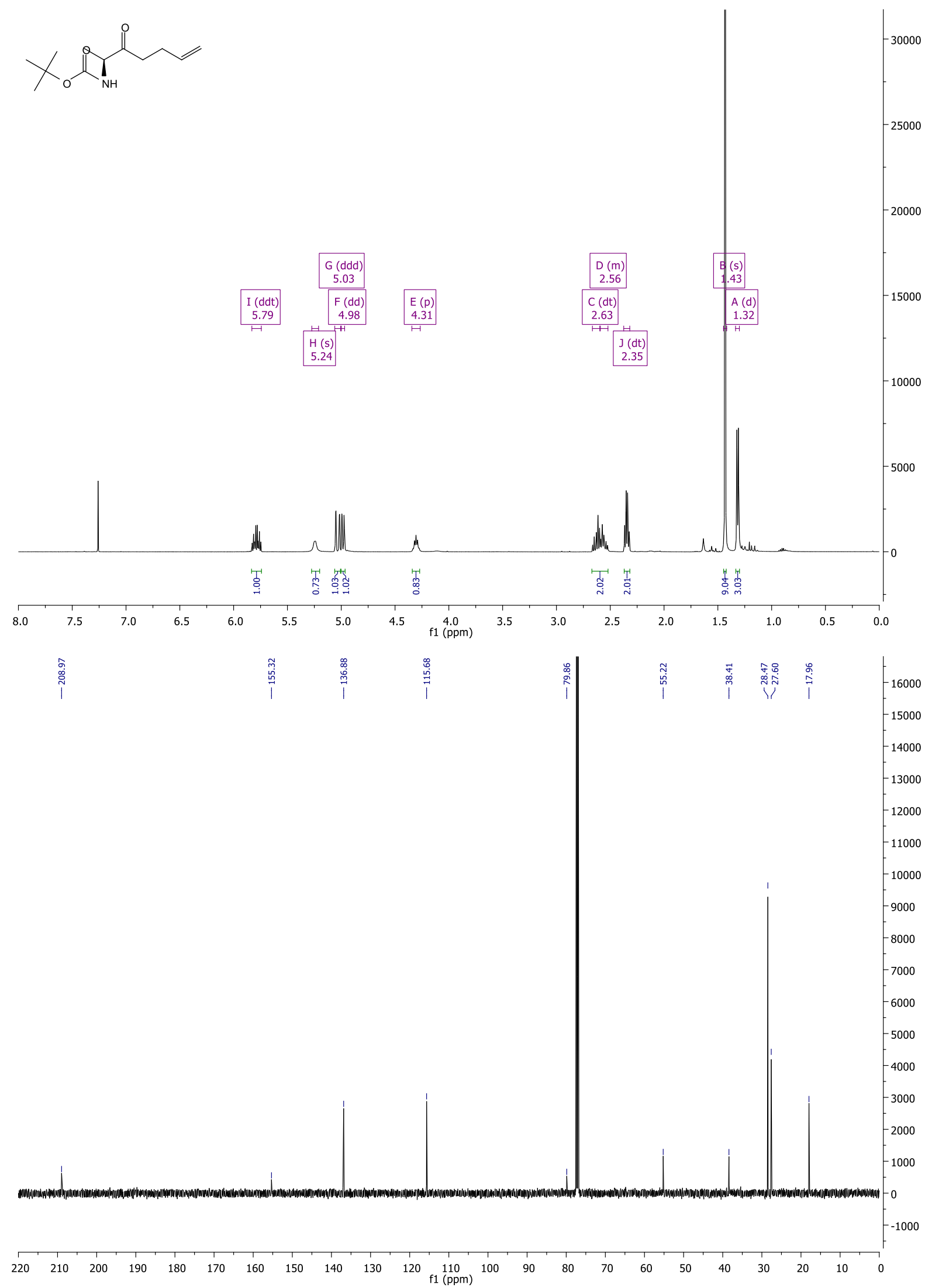


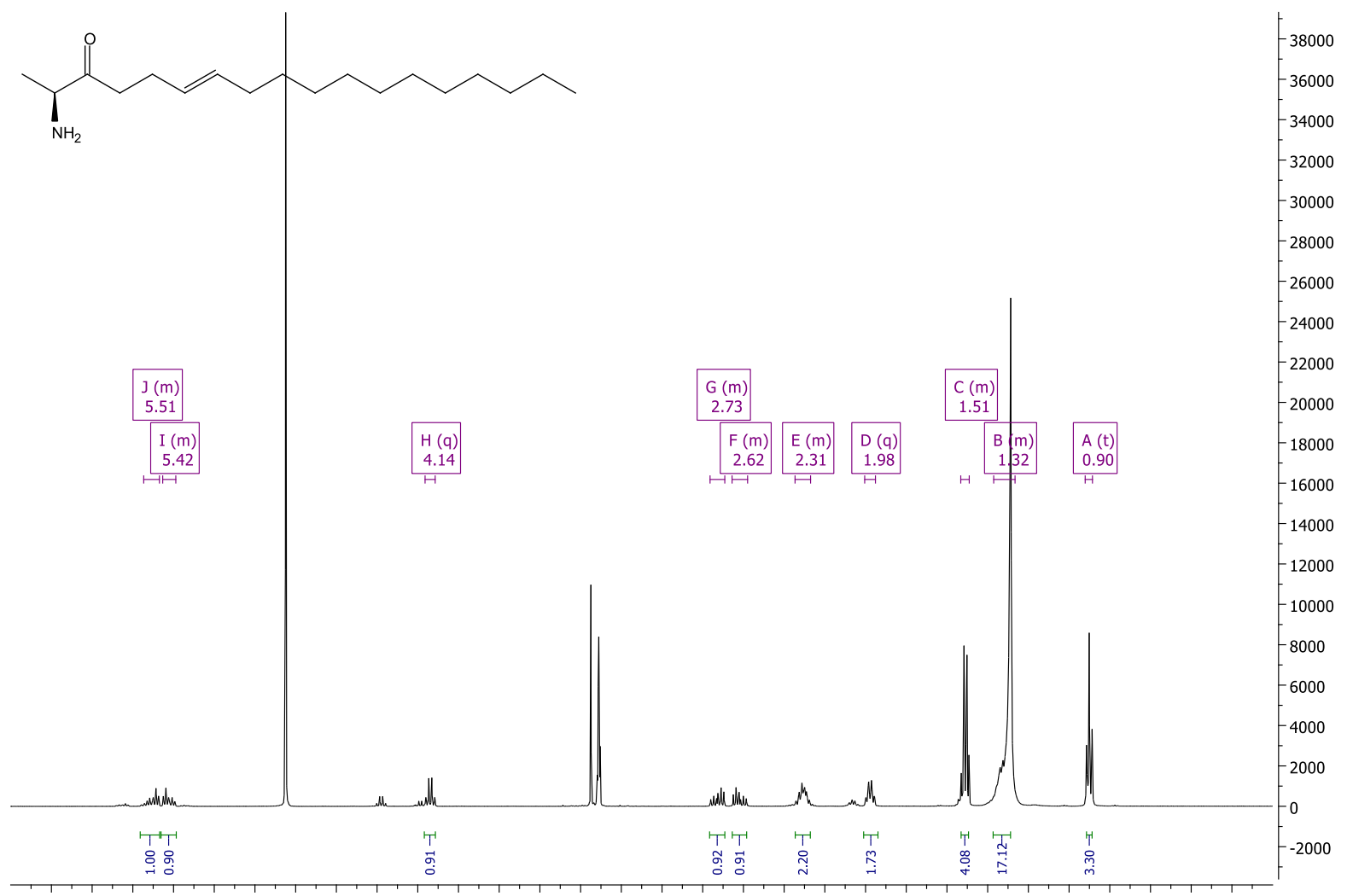

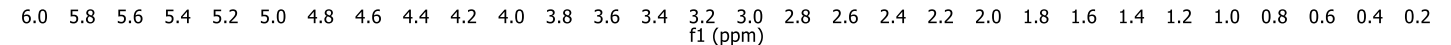

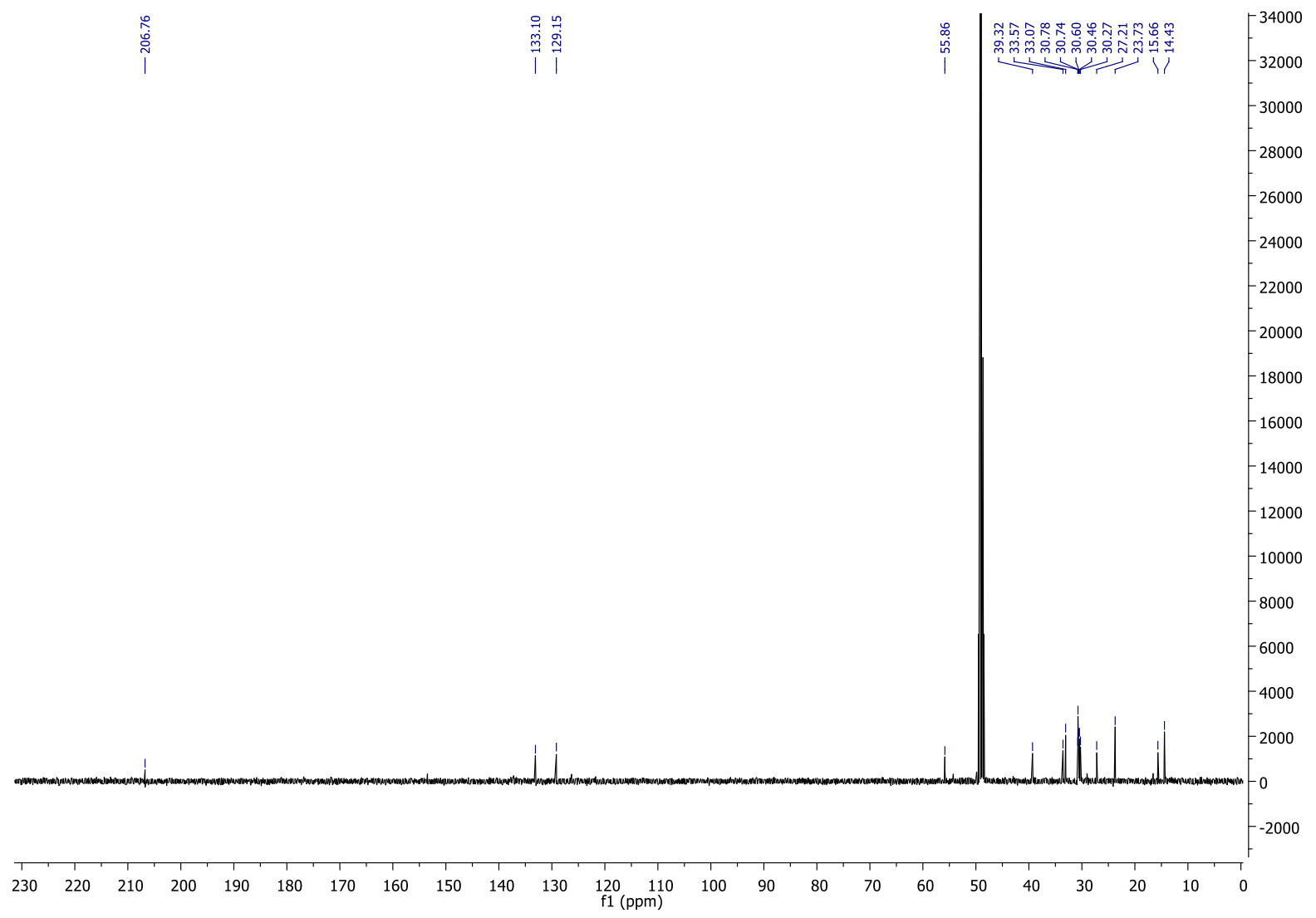



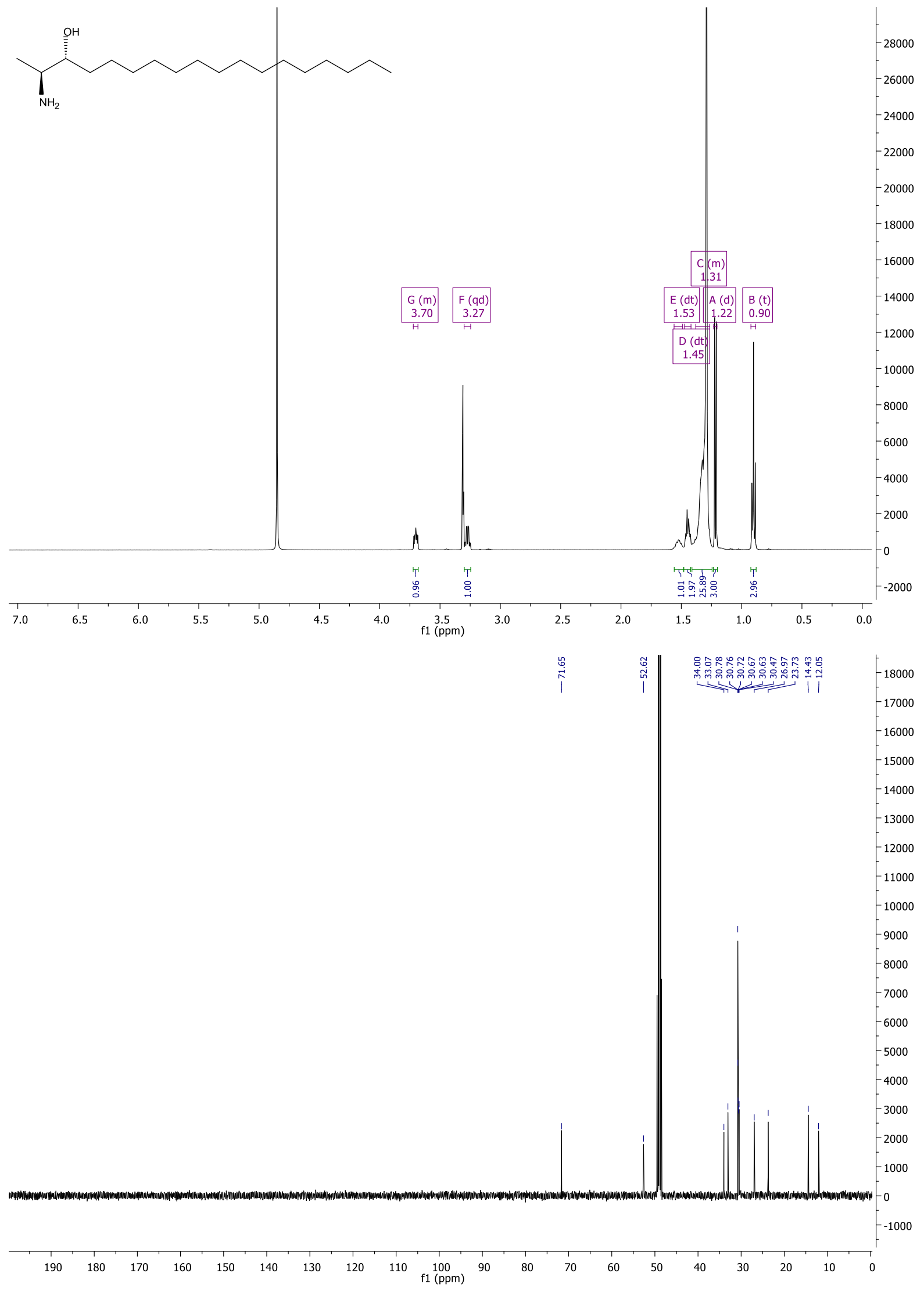


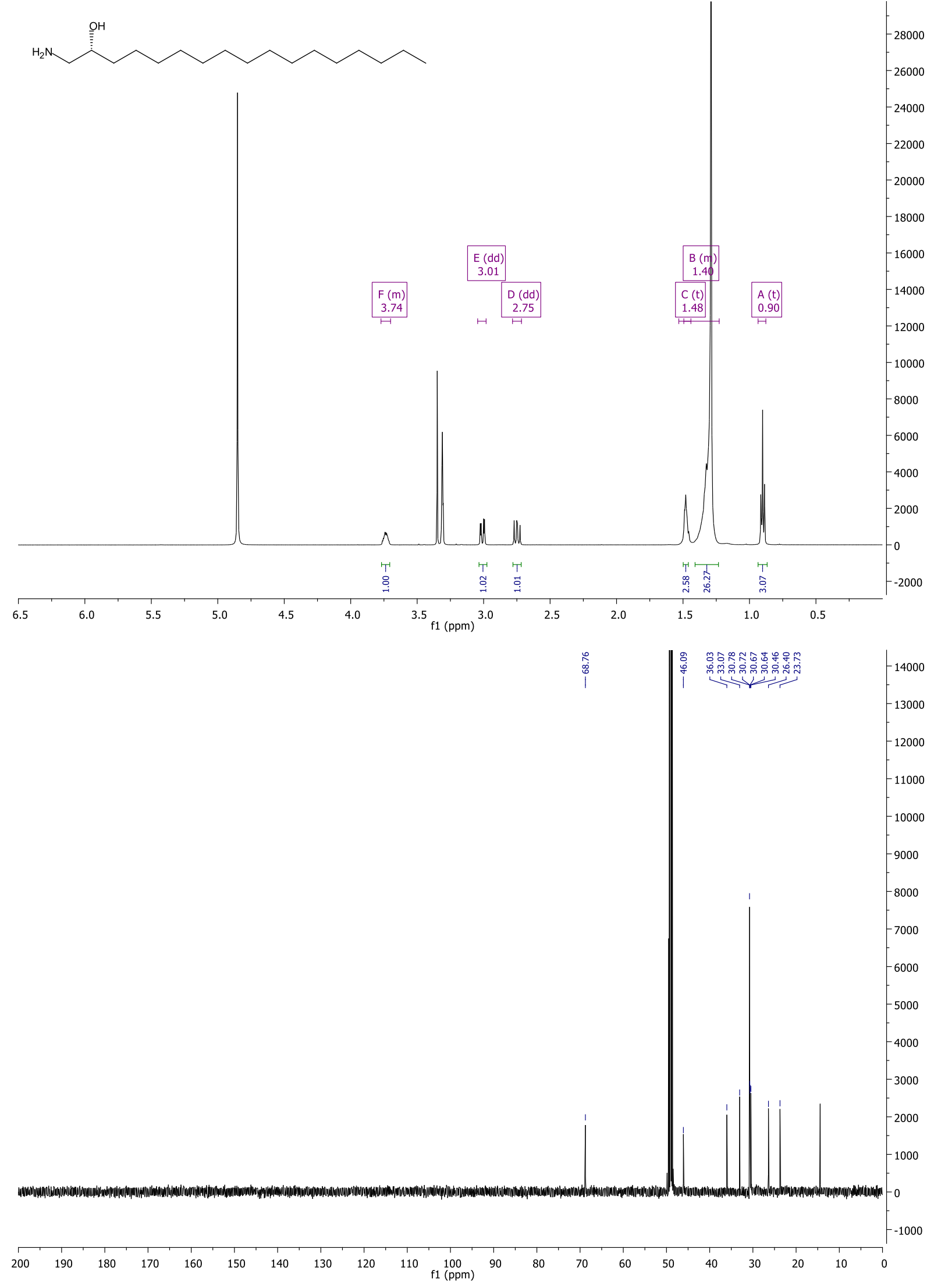



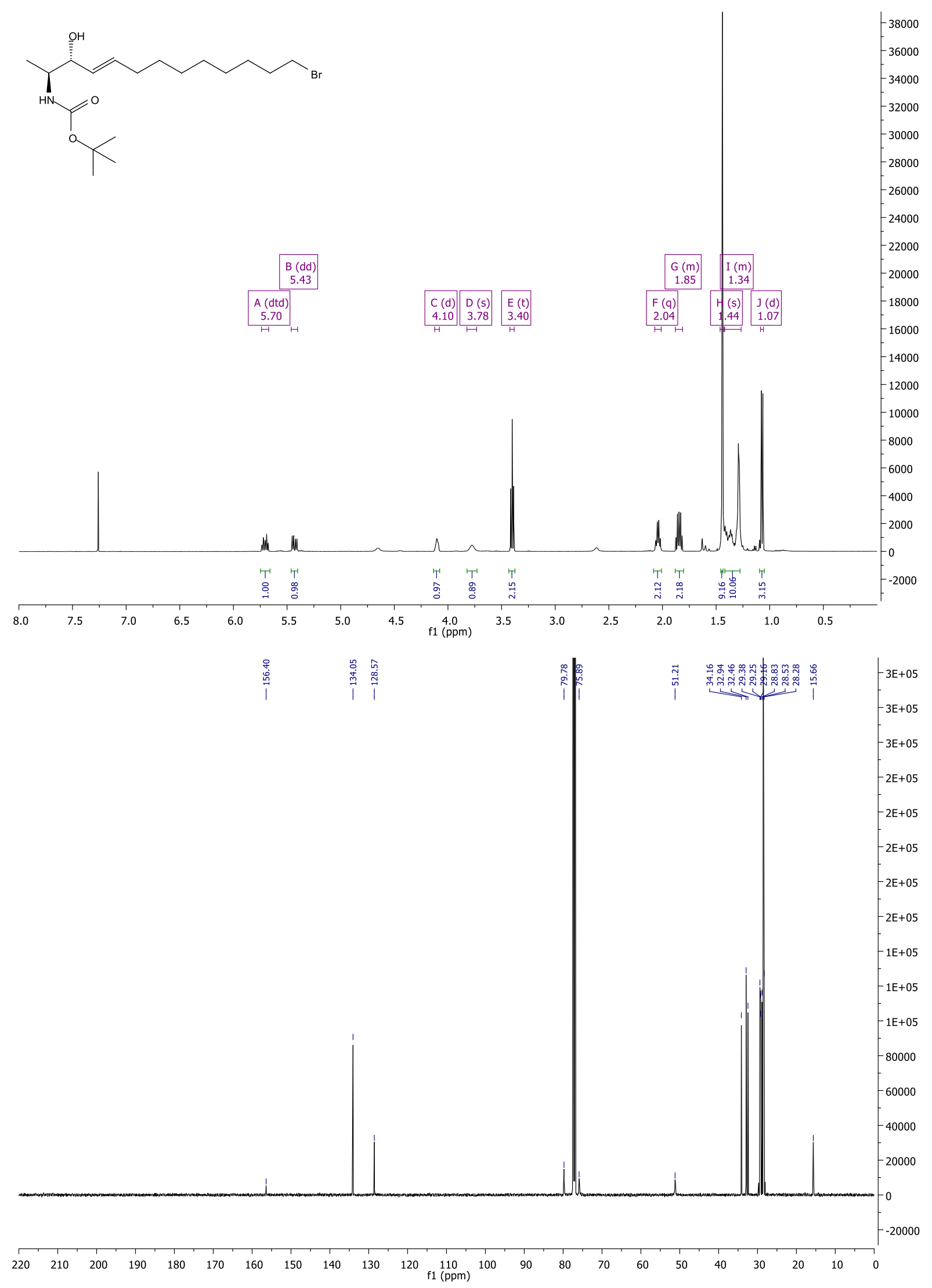

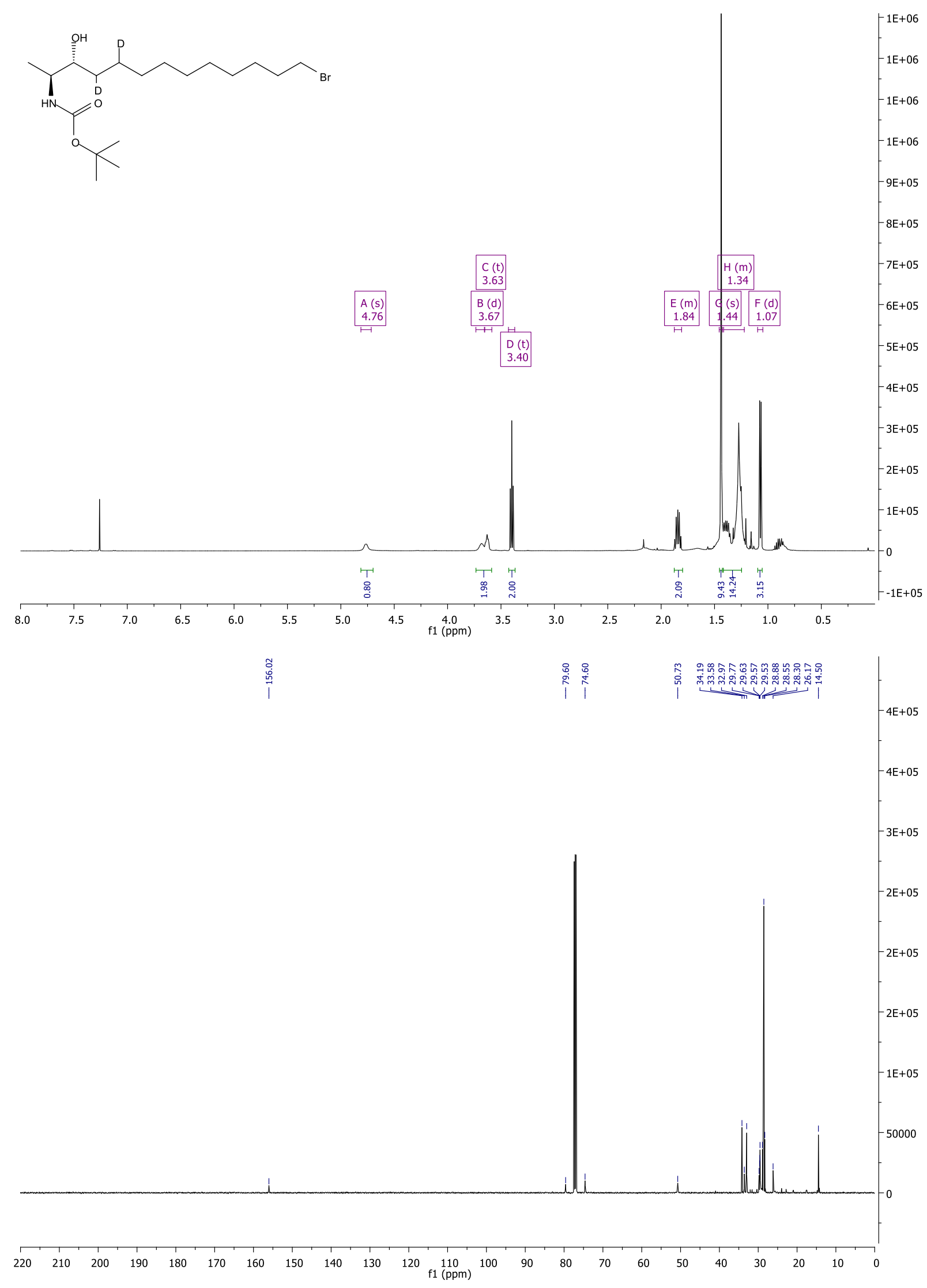

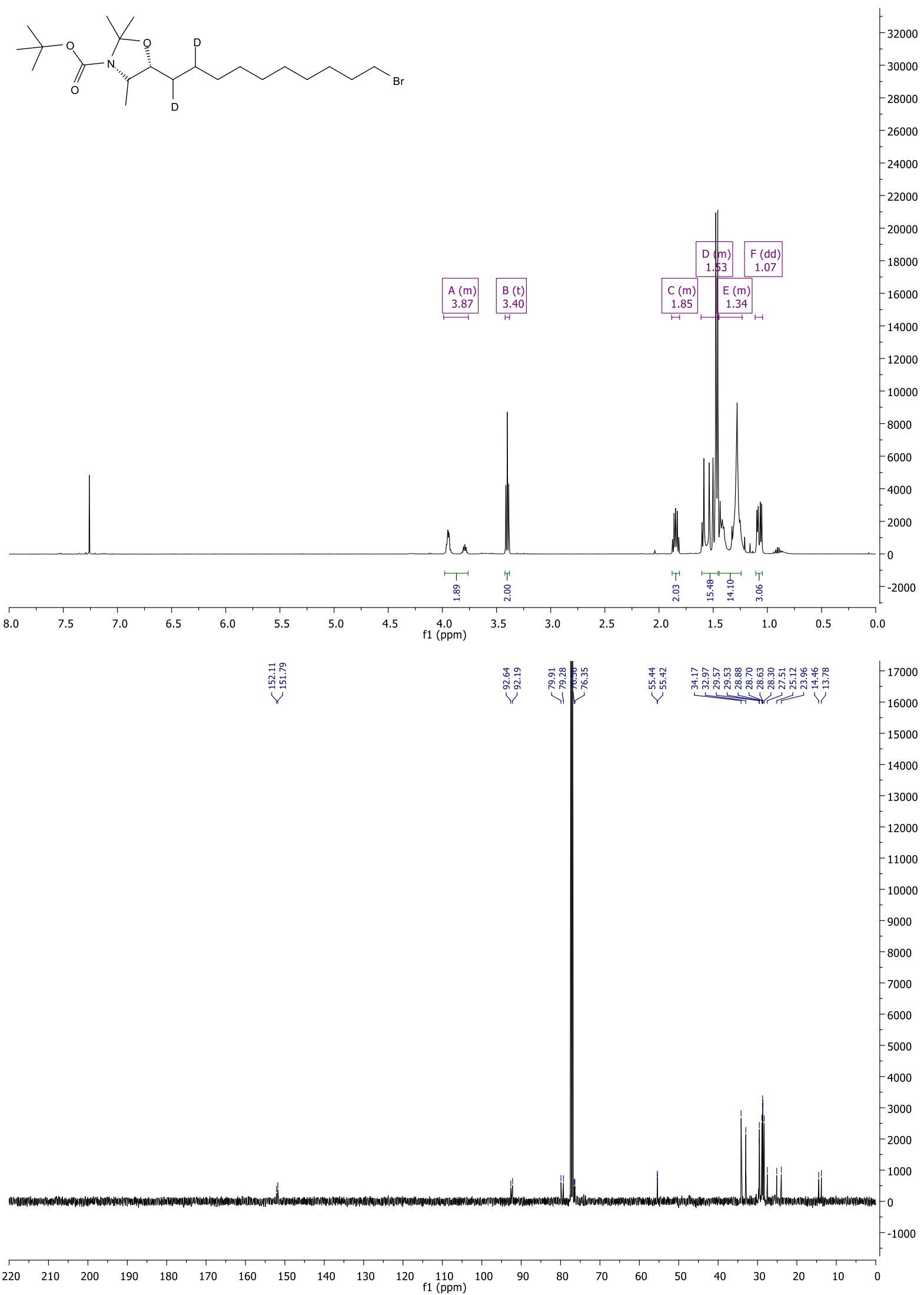

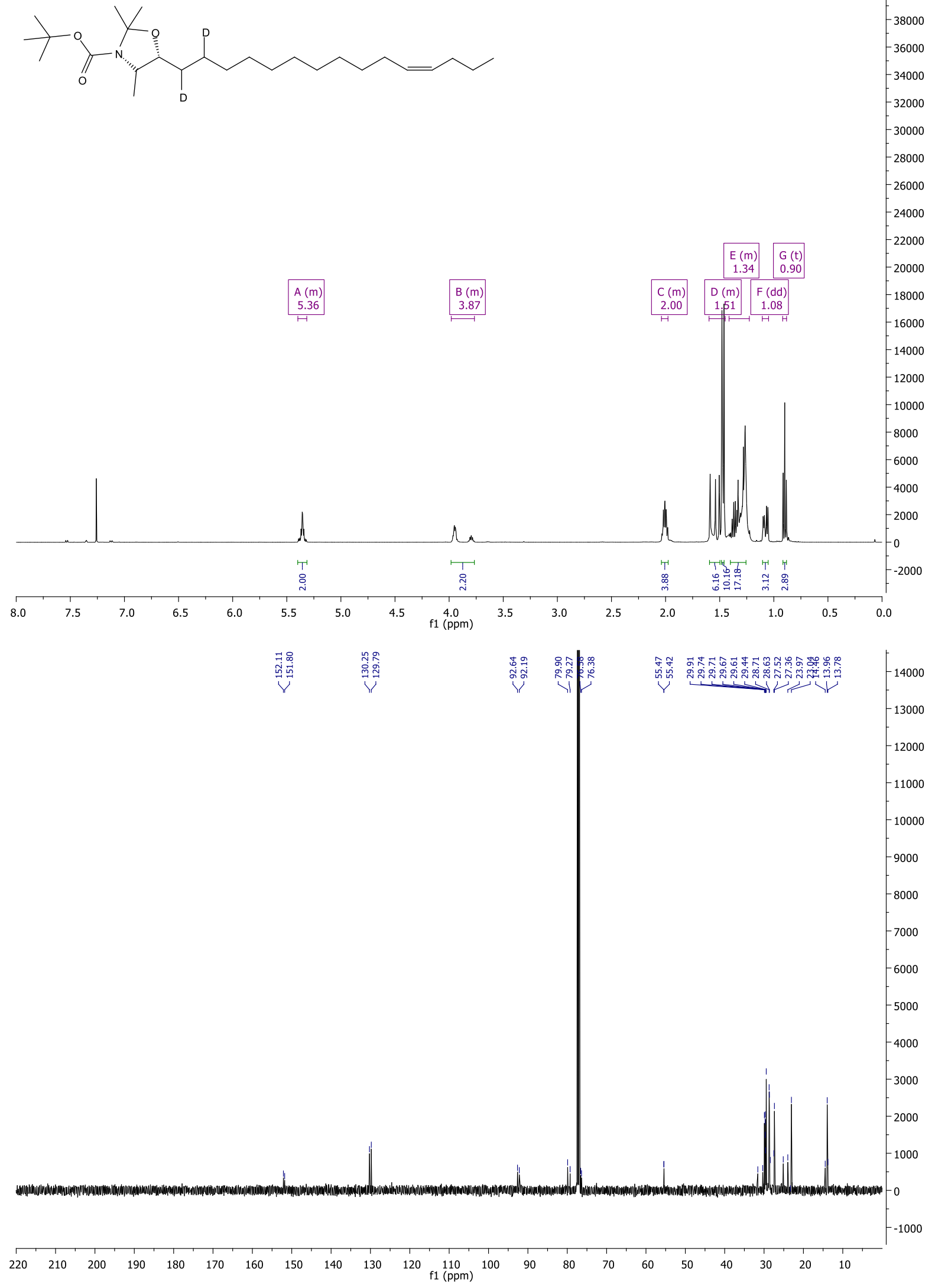

47 

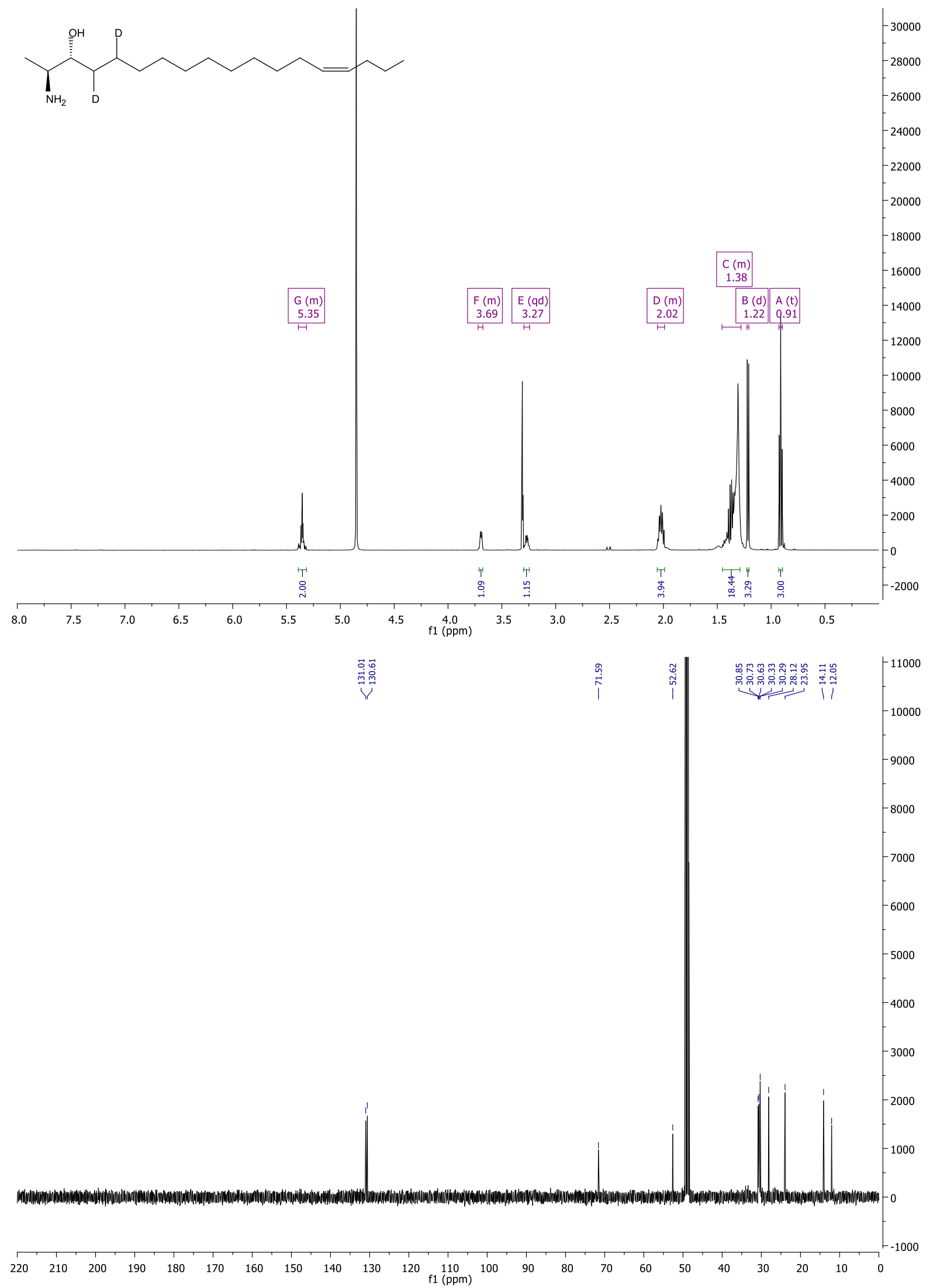


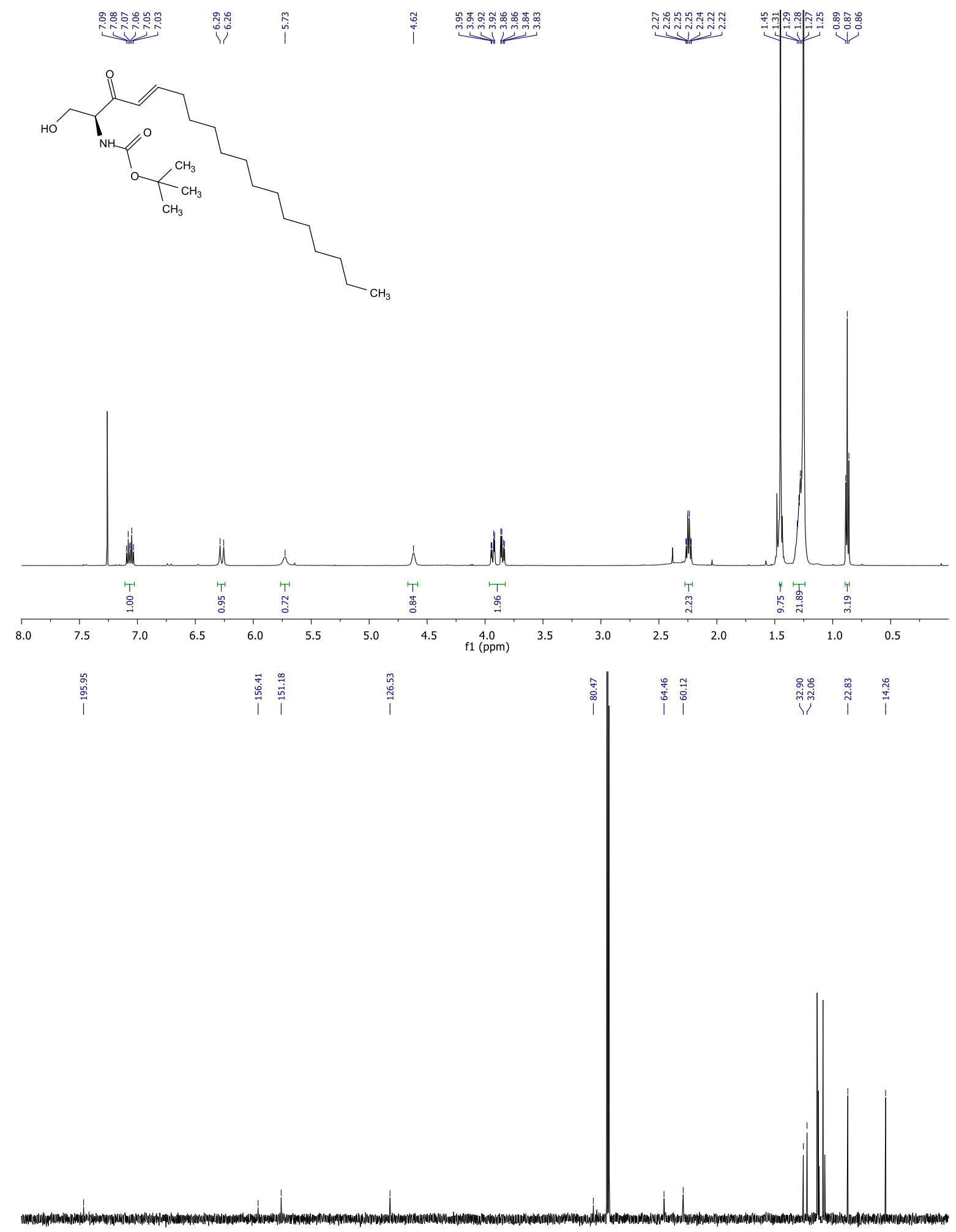

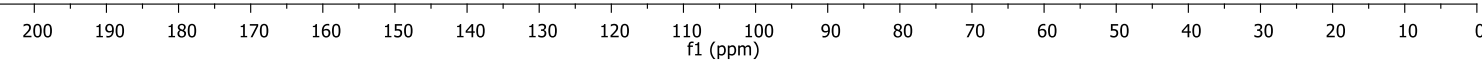




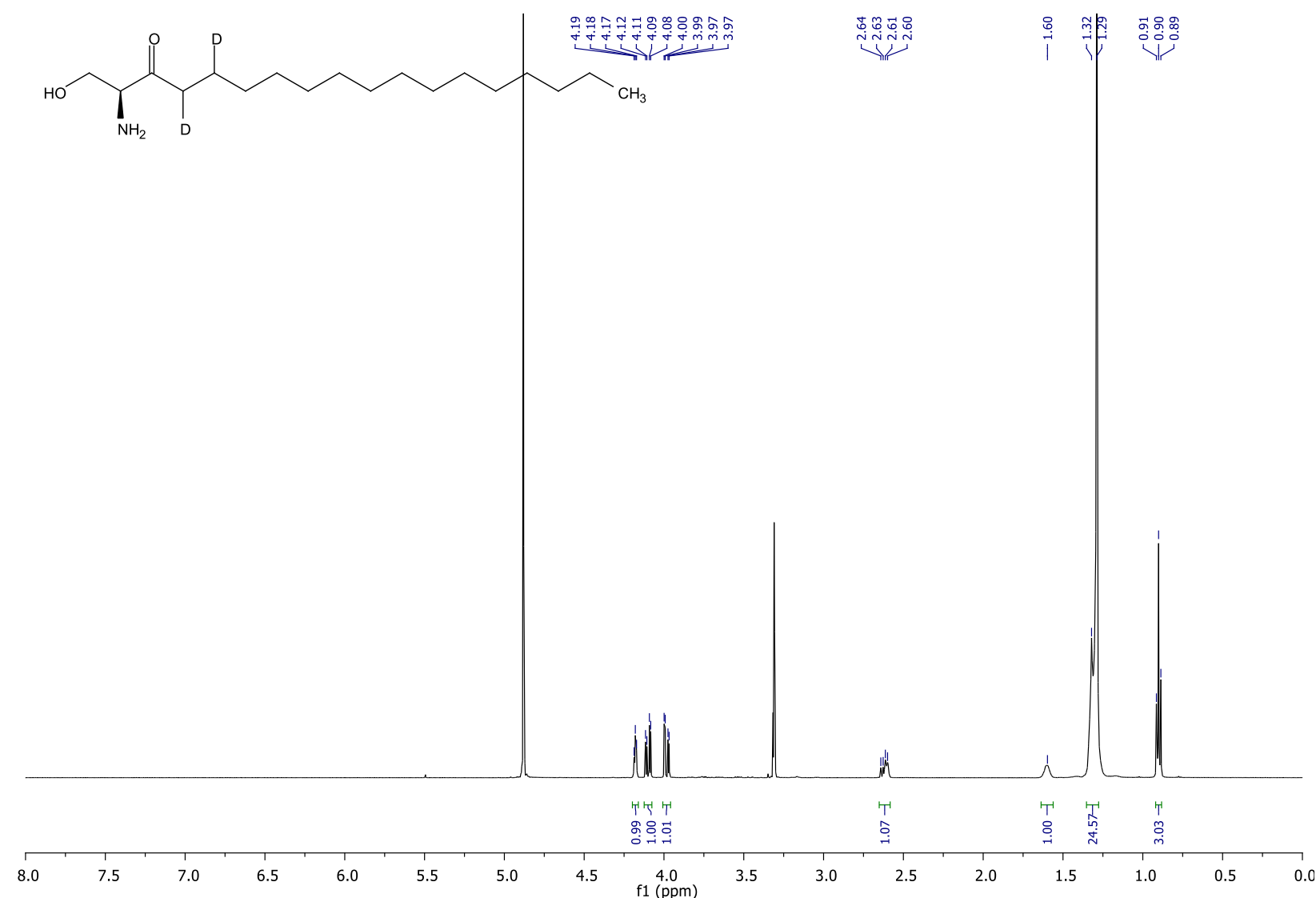

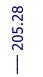

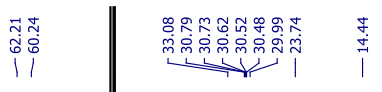

\begin{tabular}{rlllllllllllllllllllll}
\hline 210 & 200 & 190 & 180 & 170 & 160 & 150 & 140 & 130 & 120 & $\underset{\mathrm{f} 1(\mathrm{ppm})}{110}$ & 90 & 80 & 70 & 60 & 50 & 40 & 30 & 20 & 10 & 0
\end{tabular} 


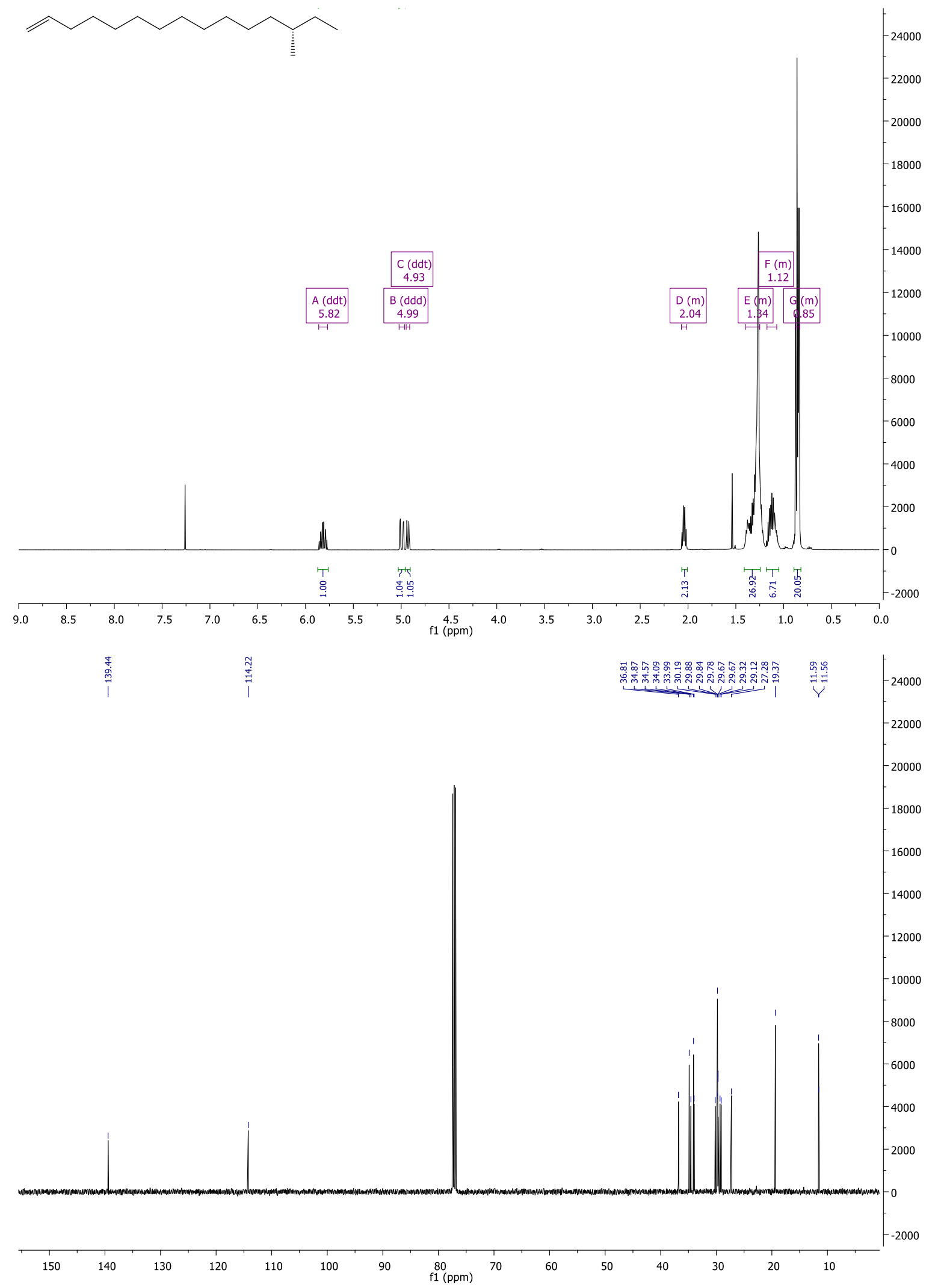



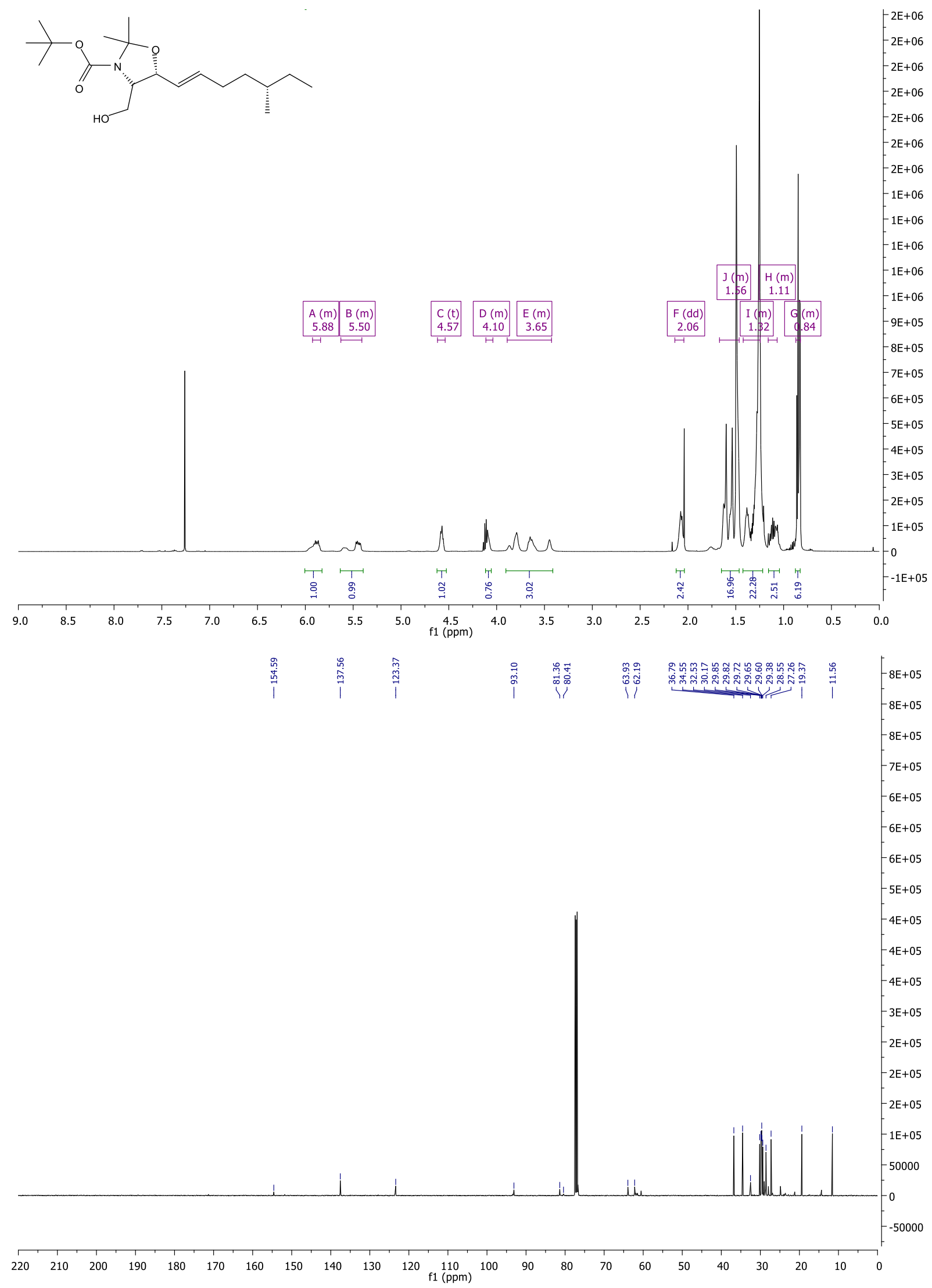

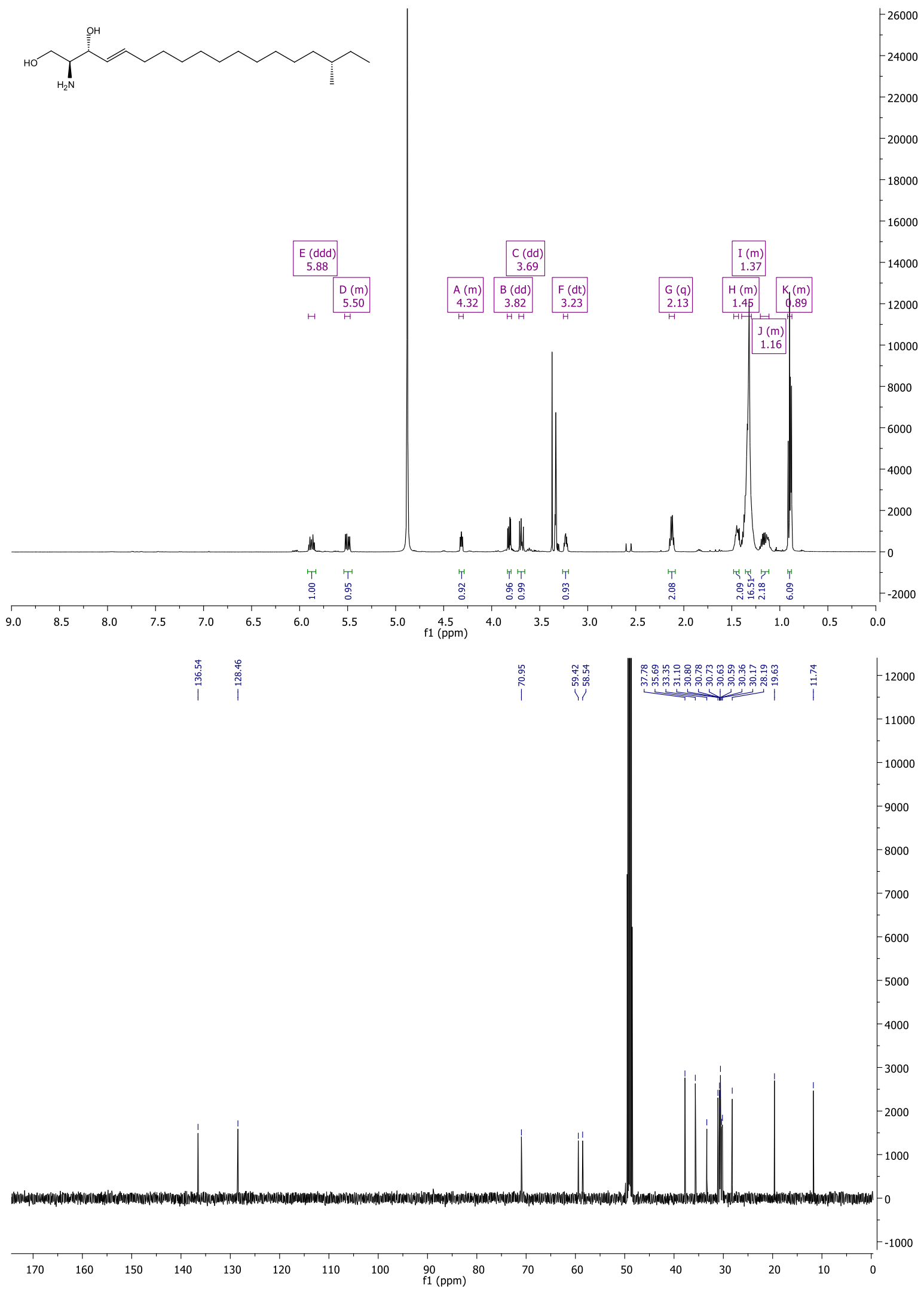
